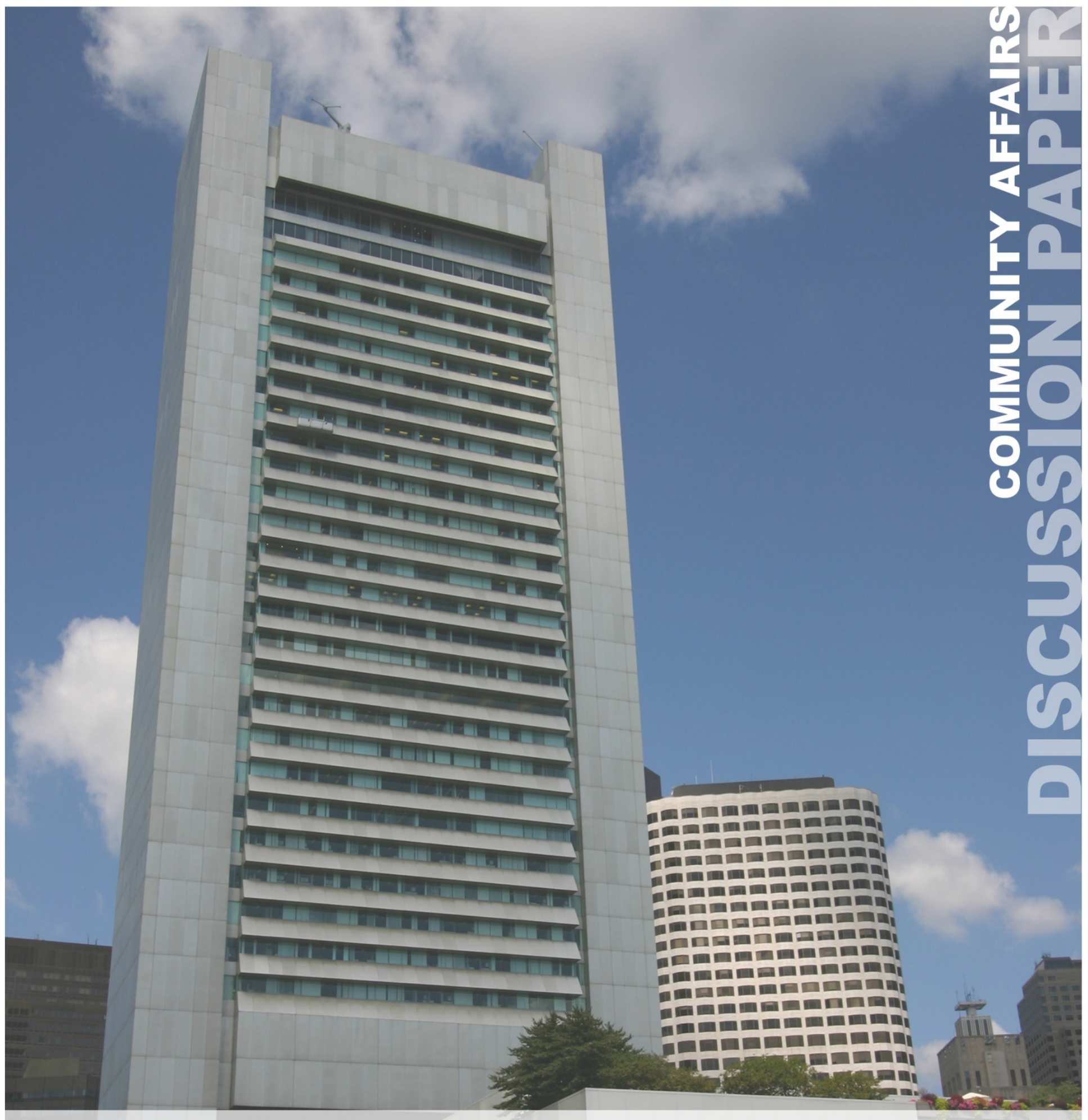

\title{
Reinvigorating Springfield's Economy: Lessons from Resurgent Cities
}

Yolanda K. Kodrzycki and Ana Patricia Muñoz with Lynn Browne, DeAnna Green, Marques Benton, Prabal Chakrabarti, David Plasse, Richard Walker, and Bo Zhao 


\title{
Reinvigorating Springfield's Economy: Lessons from Resurgent Cities
}

\author{
Yolanda K. Kodrzycki and Ana Patricia Muñoz \\ with Lynn Browne, DeAnna Green, Marques Benton, Prabal Chakrabarti, David Plasse, Richard Walker, \\ Bo Zhao
}

August 11, 2009

\begin{abstract}
:
As part of the Federal Reserve Bank of Boston's commitment to supporting efforts to revitalize the economy of Springfield, Massachusetts, this paper analyzes the economic development approaches of other mid-sized manufacturing-oriented cities during the past half century. From among a comparison group of 25 municipalities that were similar to Springfield in 1960, the study identifies 10 "resurgent cities" that have made substantial progress in improving living standards for their residents, and that are recognized as vital communities in a broader sense by experts on urban economic development and policy. These case studies suggest that industry mix, demographic composition, and geographic position are not the key factors distinguishing the resurgent cities from Springfield. Instead, the most important lessons from the resurgent cities concern leadership and collaboration. Initial leadership in these cities came from a variety of key institutions and individuals. In some cases, the turnaround started with efforts on the part of the public sector, while in other cases nongovernmental institutions or private developers were at the forefront. Regardless of who initiated the turnaround, economic redevelopment efforts spanned decades and involved collaborations among numerous organizations and sectors.
\end{abstract}

Yolanda Kodrzycki is a senior economist and policy advisor and Ana Patricia Muñoz is a research associate at the Federal Reserve Bank of Boston. Their email addresses are, yolanda.kodrzycki@bos.frb.org, and anapatricia.munoz@bos.frb.org, respectively. This paper was produced in collaboration with the other members of the Federal Reserve Bank of Boston project "Toward a More Prosperous Springfield, Massachusetts."

The authors are grateful to Teresa Huie and Catherine Spozio of the Federal Reserve Bank of Boston for extensive research assistance and to external experts for sharing their knowledge of individual cities. This paper, which may be revised, is available on the web site of the Federal Reserve Bank of Boston at http://www.bos.frb.org/economic/ppdp/index.htm. The views expressed in this paper are solely those of the authors and not necessarily those of the Federal Reserve Bank of Boston or the Federal Reserve System.

The views expressed in this publication do not necessarily reflect official positions of the Federal Reserve Bank of Boston or the Federal Reserve System. This paper is jointly issued as Research Department's Public Policy Discussion Paper No. 09-7. 
The City of Springfield's economic position has eroded over the past five decades. In 1960, Springfield's median family income was slightly higher than the national average. By the mid-2000s, median family income had decreased to only about two-thirds of the national average. Springfield's poverty rate went from being a little below average in 1980 to over twice the U.S. average in recent years. To some extent, this deterioration in living standards in Springfield reflects the forces of deindustrialization and suburbanization that challenged many city economies during these decades. However, these nationwide forces do not fully account for Springfield's decline. As an earlier Federal Reserve Bank of Boston discussion paper noted, Springfield's economy worsened relative to other mid-sized manufacturing-oriented cities. ${ }^{1}$ Although Springfield's economic position was in line with its peer group in the 1960s, by 200507 , its median annual family income had fallen to nearly $\$ 4,000$ below the peer-city average and its poverty rate had risen to 4 percentage points above that level.

This paper offers lessons from other mid-sized manufacturing-oriented cities that have reinvigorated their economies more successfully than Springfield. We refer to these municipalities as "resurgent cities." This term means that these cities have made substantially more progress than other cities with similar challenges and opportunities in improving living standards for their residents, and are recognized as vital communities in a broader sense by experts on urban economic development and policy. To be sure, these cities continue to struggle with a variety of problems, many of which have become more acute with the nationwide recession that started in late 2007.

Drawing a dividing line between resurgent and nonresurgent cities ultimately involves making judgment calls, as many if not all of the cities can point to examples of successful programs and aspects of economic and social improvement. ${ }^{2}$ On the whole, however, we believe the cities designated as resurgent offer meaningful lessons to Springfield and the other remaining mid-sized manufacturing-oriented cities. To our knowledge, the approach of examining cities with a similar starting point is a new way of analyzing Springfield's development. ${ }^{3}$

\footnotetext{
${ }^{1}$ See Browne, Green, et al. (2009).

${ }^{2}$ For interesting examples of similarities and differences in expert opinions and statistical measures of urban success, see Wolman, Hill and Furdell (2000).

${ }^{3}$ For example, The MassINC Springfield Economic Growth Initiative makes use of a comparison city definition that was developed for the Brookings Institution by Furdell and Wolman (2006). Furdell and Wolman start by focusing on 302 cities that met at least one of the following criteria in either 1990 or 2000: (1) population of at least 50,000 and primary city in metropolitan area; (2) population equal to at least 50 percent of the population of the primary city in the metropolitan area; and (3) population of at least 150,000. The 65 "weak market" cities, which include Springfield, were those that fared poorly in terms of economic growth during the 1990s (measured by employment, payroll, and
} 
The research strongly suggests that industry mix, demographic composition, and geographic location are not the key factors distinguishing the resurgent cities from Springfield. Therefore, the erosion of Springfield's economic position relative to its peer cities has been due mostly to other factors. Identifying these other factors and taking the appropriate actions is likely to increase Springfield's chances of reaching its economic potential.

The most important lessons from the resurgent cities concern leadership and collaboration. Initial leadership in these cities came from a variety of key institutions and individuals. In some cases, the turnaround started with efforts on the part of the public sector, while in other cases nongovernmental institutions or private developers were at the forefront. In all cases, the instigators of revitalization in the peer group cities recognized that it was in their own interest to prevent further deterioration in the local economy, and they took responsibility for bringing about improvement. Regardless of who initiated the turnaround, economic redevelopment efforts spanned decades and involved collaborations among numerous organizations and sectors. These joint efforts involved creating new, distinct entities. The names of the collaborations in the various peer cities provide a sense of their central focus: "Economic Development Corporation," "Growth Alliance," "Civic Federation," "Center for the City," and "UniverCity Partnership," for example.

The stories of the resurgent cities involve fundamental shifts in local economies and human and physical infrastructure. Mid-sized cities that were once known for manufacturing items ranging from refrigerators and home furnishings to jewelry and cigarettes have earned new identities. Many have turned to more technology-related forms of manufacturing for part of their transformation. All of the cities have diversified their economic base away from the manufacturing sector. Among the peer group are places now being called the "Renaissance City,"“Wall Street West," “Most Intelligent Community," and "All-American City."

In addition to feeling the recent blows from a nationwide recession and financial crisis, the resurgent cities continue to face the challenges of providing quality education and training to broader segments of their populations and extending the benefits of resurgence to more of their neighborhoods. Their efforts along these lines are multifaceted, but they often involve key initiatives on the part of educational institutions and foundations.

\section{Springfield's Peer Cities and Why They are Relevant}

Figure 1 shows the locations of the 25 cities chosen for Springfield's peer group. In 1960, 27 percent of all U.S. workers had manufacturing jobs, almost as high a share as in the

number of establishments) and economic well-being of city residents in 2000 (measured by per capita income, median household income, poverty rate, unemployment rate, and labor force participation rate). 
immediate aftermath of World War II. The large concentration in manufacturing provided employees with good access to what are now referred to as "middle-class jobs." All of the peer cities relied more heavily on manufacturing than the nation as a whole. Some 30 percent or more of the employed residents of each city worked in the manufacturing sector in 1960, with an average concentration of 38 percent. ${ }^{4}$ Manufacturing's share of employment remained at least 20 percent in 1980 in each of the comparison cities.

Within this peer group, Springfield's reliance on manufacturing employment was closer to the bottom than the top (Figure 2). The city's manufacturing employment share was about one-third in 1960-similar to the share in places such as Jersey City (NJ), Fort Wayne (IN), Providence (RI), and Grand Rapids (MI). On the high end, slightly over one-half of all workers living in Waterbury (CT), Flint (MI), and Gary (IN) were employed by manufacturing firms.

The share of manufacturing jobs nationally has decreased dramatically since the early 1960s and, in fact, the total number of people employed in the U.S. manufacturing sector is lower now than it was then. In addition, manufacturing work has shifted increasingly to suburban areas, making it that much harder for city residents to access these jobs. ${ }^{5}$ And although current average pay levels in some other industries with urban locations (such as finance and professional and technical services) are now as high as or even higher than pay in manufacturing, the educational and skill requirements for obtaining such jobs are in many cases quite different from those in the manufacturing industry. Thus, in addition to the loss of manufacturing jobs, the peer group cities have faced greater-than-average challenges related to preparing their residents for new types of work. In-migration of individuals and families with low levels of schooling or other training has further compounded these problems. Finally, the process of adjusting to job losses in manufacturing has arguably been harder than the adjustment to losses in some other sectors because many manufacturing plants were large. Plant shutdowns and permanent layoffs in manufacturing have tended to cause sharp spikes in local unemployment.

The choice of peer cities was based also on the role of the city in its region and on the size of its population. Like Springfield, each of the other cities constitutes the primary urban

\footnotetext{
${ }^{4}$ Many of the statistics in Decennial Censuses and other surveys refer to data as of the prior year. This study follows common practice in ignoring slight discrepancies in timing across data from a single source. Thus, all information from the 1960 Census, for example, is treated as if it pertained to the year 1960.

${ }^{5}$ In the 1950s, 70 percent of all jobs in metropolitan areas of the United States were located in central cities; by 1990, the central-city share had dropped to 45 percent, and the nation was "approaching the time when ... only about 40 percent of MSA jobs [would] be located [in central cities]." See Mieszkowski and Mills (1993). For the mid-2000s, a recent study found that only 21 percent of all metropolitan-area jobs were located within three miles of the central business district. For manufacturing, the share was even smaller, 14 percent. See Kneebone (2009).
} 
center of its respective metropolitan area. ${ }^{6}$ Most had between 100,000 and 250,000 residents from 1960 to 1980, although a few started with larger populations in 1960 before shrinking in size.

In contrast to its below-peer-group-average reliance on manufacturing, Springfield's 1960 population of 174,000 placed it in the upper half of the peer group, and similar in size to Gary and Grand Rapids (Figure 3). The largest city in terms of population was Rochester (NY), with just over 300,000 inhabitants. Other cities with more than 200,000 residents were Akron, Jersey City, Dayton, Syracuse, and Providence. The smallest cities in the peer group-with fewer than 110,000 residents - were Peoria (IL), Waterbury, and Allentown (PA).

As shown below, none of the peer cities with over 40 percent dependence on manufacturing in 1960 has yet achieved resurgent status. By contrast, size in and of itself is considered neither an advantage nor a disadvantage in economic adjustment. The logic is more that a mid-sized city that constitutes the primary urban center of its region faces a somewhat different array of challenges and opportunities than a city that is substantially different in scale or has strong, geographically induced ties to a large city. ${ }^{7}$

Large cities often are home to prominent businesses and institutions that have ample financial and civic capacity, and that attract or spin off other enterprises. Small-to-mediumsized municipalities located on the fringes of such large cities may find themselves benefiting from these spillovers-or, on the other hand, suffering if the nearby large city falls into economic decline.

Small cities may benefit from having cohesive social networks that facilitate public decision-making. By contrast, medium-sized cities often have diverse populations. Reaching consensus may be difficult when residents have different backgrounds and life experiences. On the other hand, diversity can be a strength. Valuable in themselves, differing perspectives and skills may foster innovation and creativity, and may offset the tendency to build a city economy centered on a single dominant industry or institution.

\section{Defining Resurgence}

Although the 25 peer cities were quite similar to one another and to Springfield in 1960, their paths have since diverged. Broad measures of the economic well-being of residents plus other information on community vitality drawn from a wide range of reports, books, and

\footnotetext{
${ }^{6}$ The specific concept used is the metropolitan statistical area (MSA), defined by the U.S. Office of Management and Budget.

${ }^{7}$ For a more extensive discussion of the role of city size in economic development, see Fox and Axel-Lute (2008).
} 
newspaper articles were used to characterize the cities. This study concentrates on examining long-term trends, as opposed to more temporary developments associated with business cycles.

As a first cut, resurgent cities were defined as those showing better performance than Springfield in each of the following respects as of the mid-2000s: ${ }^{8}$

- Median family income

- Change in median family income ranking since 1960

- Poverty rate

- Percentage point change in poverty rate since $1980^{9}$

- $\quad$ Percent change in population since 1960.

Median family income measures the financial resources of the typical family, while the poverty rate provides an indication of the share of residents who have difficulty satisfying even basic living needs. Both measures are related to the availability and quality of jobs for city residents. Population change is included as a secondary factor. A declining population indicates that a city offers inadequate economic opportunities or amenities to retain its residents, let alone attract new residents. Cities with population losses have difficulty raising enough own-source revenues to fund public services.

Three of the cities ultimately selected for the resurgent category-Providence, New Haven, and Evansville-actually had population losses from 1960 to the mid-2000s slightly larger than Springfield's, but there was ample other evidence of their successful transformation. Providence and Evansville, for example, have shown major improvements since 1960 in median family income relative to the other cities. Among other indicators of success, New Haven has gone from having one of the highest crime rates in the 1970s to having one of the lowest in the 2000s. In general, all three of these cities appear to have more positive reputations in the media and in various urban comparisons than Springfield.

On the other hand, Bridgeport outperformed Springfield according to all of the statistical selection criteria other than population change. The City of Bridgeport was forced to

\footnotetext{
${ }^{8}$ Most of the historical statistics used in this study are drawn from decennial Censuses, including the information obtained through sampling U.S. households. In the 2000 Census, for example, one of every six households received the "long form" which required them to answer detailed questions on social, economic, and housing characteristics in addition to the basic questions asked of all households on age, sex, race, Hispanic origin, household relationship, and owner/renter status. Starting in 2005, the Bureau began to administer the American Community Survey (ACS) in order to collect detailed information of the sort previously obtained from the long form. The most recent data for Springfield and the comparison cities are published in two forms. The 2007 ACS 1-year estimates describe average characteristics for calendar year 2007, while 2005-2007 ACS 3-year estimates describe average characteristics for the period of calendar years 2005, 2006, and 2007. This study relies on the 2005-2007 ACS 3-year estimates because they are based on larger samples and therefore contain less sampling error.

${ }^{9}$ The 1980 Census was the first to measure population poverty rates.
} 
declare bankruptcy in 1991, but has since seen substantial economic development. It was excluded from the resurgent city category because of ongoing serious social issues. In particular, Bridgeport's low educational attainment, high crime rate, and governance problems continue to detract from its overall reputation.

\section{Measuring Success}

Table 1 shows the key economic indicators for all the peer cities. The resurgent cities are shown at the top: Evansville (IN), Fort Wayne (IN), Grand Rapids (MI), Greensboro (NC), Jersey City (NJ), New Haven (CT), Peoria (IL), Providence (RI), Winston-Salem (NC), and Worcester (MA). Figure 4 summarizes these indicators, comparing the data for Springfield to the averages for the resurgent cities and the averages for the remaining cities.

As alluded to in the introduction, median family income in Springfield fell from 106 percent of the U.S. median in 1960 to only 65 percent in 2005-07. ${ }^{10}$ Consequently, 17 cities had higher median family income than Springfield in the mid-2000s, up from only 12 in 1960 . As a group, the mid-sized manufacturing cities have become less prosperous than the nation as a whole. In 2005-07, the average median family income in the resurgent cities was $\$ 49,521,18$ percent lower than the U.S. median. Springfield's median family income of $\$ 39,371$ was similar to the average for nonresurgent cities.

Springfield's poverty rate has risen nearly 10 percentage points since 1960, from 18 percent to just under 28 percent. This is a far greater increase than in the resurgent city group ( 4 percentage points on average). Springfield also compares somewhat unfavorably with the remaining cities in its share of poor residents. In 2005-07, the average poverty rate in the nonresurgent cities was about 26 percent; among these cities, Akron, Allentown, Bridgeport, Erie, Paterson, Rockford, South Bend, and Waterbury all had lower fractions of poor people than Springfield.

On average, the resurgent cities had about 18 percent more residents in 2005-07 than in 1960. Springfield's population fell 15 percent over this time period. The city's population decline from 1960 to 1980 was in line with the nonresurgent city average, but Springfield suffered somewhat smaller population losses after 1980 than was typical in other nonresurgent cities.

To some extent, the resurgent cities have been able to increase their populations and median family incomes by adding adjacent suburban land. In fact, Table 1 shows that all of the resurgent peer cities outside New England-but none within New England-have been able to

\footnotetext{
${ }^{10}$ As noted in footnote 8, the three-year period 2005-07 is used instead of a one-year period $(2005,2006$, or 2007) in
} order to reduce sampling error. 
grow through annexing adjacent land. In the case of Fort Wayne, which more than doubled in acreage between 1960 and 2000, annexation was a conscious economic improvement strategy. In general, however, it is hard to gauge the degree to which annexation was a cause-as opposed to an effect-of population increase and economic growth.

\section{Characteristics of Resurgent and Nonresurgent Cities}

Before turning to more detailed accounts of how the resurgent cities came to differ from Springfield, it is useful to examine certain additional summary characteristics of resurgent and nonresurgent cities. This section of the study looks at region of the country, population, industry concentration, race and Hispanicity, and crime. Doing so provides an initial indication of whether Springfield faced unusually strong obstacles to success or pursued different industry strategies than the more successful comparison cities.

The data indicate that successful transformation was only weakly linked to geography. On the one hand, the group of 10 resurgent cities includes the two Southern peer cities, Greensboro and Winston-Salem, but none of the cities from Ohio, Pennsylvania, or New York. Otherwise, however, except for tiny Rhode Island, each of the states represented in the comparison group has both at least one resurgent city and at least one nonresurgent city. In New England, New Haven, Providence, and Worcester have developed more successfully than Springfield, Bridgeport, Hartford, or Waterbury. These findings suggest that although statewide policies - such as North Carolina's pro-growth stance-may have been a factor in easing economic adjustment, cities ultimately play an important role in determining their own fates.

Economic resurgence was virtually uncorrelated with city population size. (See Table 1 and Figure 3, where the resurgent cities are depicted by darker bars and the remaining peer cities by lighter bars.) Gary and Grand Rapids had almost identical populations in 1960, yet their economic performance over the next five decades differed considerably. The same conclusion applies to Hartford and Fort Wayne, or Erie and Evansville.

The clearest predictor of resurgence was initial manufacturing intensity (Table 2 and Figure 2). None of the cities where over 40 percent of employed residents had manufacturing jobs in 1960 has yet managed to make a successful transition to the "post-industrial" economy. Springfield, however, is one of the few cities in the comparison group-along with Syracuse and Hartford - that has not yet made a successful transformation despite having had relatively low reliance on manufacturing jobs in 1960. In other words, the fact that 34 percent of Springfield's employed residents held manufacturing jobs in 1960 may help to explain the city's current economic distress, but it does not explain why Springfield continues to lag behind its peer cities. 
In 1960, other sectors of urban economies provided far fewer jobs than manufacturing. The second largest industry for the peer group cities was retail and wholesale trade, which generally employed between 15 and 20 percent of resident jobholders (Table 2). Employment shares in all of the remaining industries were in the single-digits. Springfield had a greater concentration of employment in finance, insurance, and real estate than any of the resurgent cities except Jersey City, but the number of residents who worked in finance and related industries in Springfield was less than one-fifth of the number who worked in manufacturing.

\section{Industry mix today}

Table 3 shows employment patterns for peer city populations as of 2005-07.11 The declining dependence on manufacturing is striking. On average, only about 14 percent of residents of all the cities were employed in the manufacturing sector in the mid-2000s. In the comparison group, more residents worked in health care and social assistance than in manufacturing. In addition, a number of other industries were major employers of urban populations, especially retail trade, education, and leisure and hospitality. Industry diversification has become the norm in both the resurgent and the nonresurgent cities.

Among the resurgent cities, there are some notable differences in industry mix, suggesting variation in their economic development strategies. Jersey City residents are much more likely to find work in financial and other professional services than residents of the other resurgent cities. One-fifth of New Haven's employed adults work in the education sector. Providence has a greater concentration of workers in the leisure and hospitality category (including hotels, restaurants, arts, and entertainment) than the other cities shown. The four relatively successful cities in the Midwest-Evansville, Fort Wayne, Grand Rapids, and Peoria - have diversified away from manufacturing, but nevertheless remain somewhat more dependent on manufacturing than their peers in other parts of the country.

Finally, the data on employment shares provide insights on how Springfield compares with the other cities. The most striking difference is that 19 percent of Springfield residents are employed in health care and social assistance. Among the resurgent cities, the average share is under 15 percent, and the highest is 17 percent (in New Haven).

Springfield's high reliance on health care and social assistance jobs is not necessarily good or bad. However, it does suggest that the city may want to give some thought to strategies that attract other types of employers to the city-or that improve residents' access to

\footnotetext{
${ }^{11}$ Data on industry composition by city are more detailed for 2005-07 than for 1960. In addition, industry definitions changed when U.S. statistical agencies shifted to using NAICS (North American Industry Classification System) rather than SIC (Standard Industrial Classification) codes to classify jobs. Reflecting changes in the economy, NAICS codes provide more information on nonmanufacturing industries than was provided in SIC codes.
} 
(or qualifications for) jobs in other sectors. Springfield residents are less likely to be employed in the professional and business services sector or in educational services than residents of the resurgent cities. Springfield's employment shares in retail trade and manufacturing are also on the low side.

\section{Demographic changes: race and Hispanicity}

No account of changes in the peer cities would be complete without mention of race and ethnicity. In 1960, the peer group cities were not very different from the nation as a whole in their racial composition. On average, whites comprised 87 percent of city populations, compared with 95 percent of the national population. Now, however, the peer city populations are much more racially mixed than many other parts of the United States. As of 2005-07, the average city in the comparison group was 56 percent white and 44 percent nonwhite-that is, people who characterized themselves as Black, Asian, or other races (Table 4). The mix for the nation in 2005-07 was 76 percent white and 24 percent other racial categories.

As in most other medium-sized manufacturing-intensive cities in New England and the Midwest, in 1960 over 90 percent of Springfield's population was white. In 2005-07, Springfield had a relatively low white share, 52 percent. Thus, like the nonresurgent cities on average, Springfield has undergone a far more dramatic change in its racial composition over the last five decades than the nation.

However, most of the resurgent cities also have experienced noteworthy changes in racial composition. In 2005-07, their populations were 62 percent white, on average, and two of the resurgent cities-Jersey City and New Haven-went from being over 85 percent white in 1960 to having nonwhite majorities in 2005-07. The change in racial mix in Providence over this period was quite similar to Springfield's.

Where Springfield differs most notably from its comparison group is in its ethnic composition. About one-third of Springfield's population is Hispanic-roughly twice the average shares of either the resurgent or the nonresurgent group, and higher than in any of the resurgent cities except Providence (Table 5). Jersey City had the second highest share of Hispanics among the resurgent cities in 2005-07. The presence of Hispanics in Jersey City is more longstanding, however. In 1980, nearly one out of every five residents of Jersey City was of Hispanic origin.

On balance, these findings suggest that Springfield officials should be particularly interested in any steps that the peer cities have taken to improve the economic situations of nonwhites and non-Anglos. While not focusing primarily on issues of diversity and inclusion, the overviews of resurgent cities below include some examples of pertinent initiatives. 


\section{Evidence on crime}

Resurgent cities have done a much better job in reducing crime rates than the other peer cities. While the average crime rate ${ }^{12}$ in 1975 was almost identical in the two groups, in 2007, the crime rate in the average resurgent city was 17 percent lower (Table 6) than in the average nonresurgent city. New Haven and Worcester went from having among the highest crime rates among the comparison cities in 1975 to having among the lowest rates in 2007. In the resurgent group, three cities had relatively high overall crime rates in 2007: Greensboro, Winston-Salem, and Grand Rapids.

Springfield's relative position among the peer cities deteriorated. In 1975, its overall crime rate was a little below average. In 2007, it was about 29 percent higher than the average rate among resurgent cities and about 7 percent higher than among the other cities. Moreover, the rate of violent crime in Springfield was the second highest among all the peer cities (behind Flint, which had an exceptionally high prevalence of violent crime).

\section{Resurgence in 10 Peer Cities}

Having identified the resurgent cities and quantified key economic and social differences between these cities and Springfield, the study now turns to case studies of individual cities. It starts with a brief economic history of Springfield from 1960 to the present. Similar accounts follow for each of the resurgent cities, focusing on their challenges and economic development efforts. Figures 5 to 15 in the text highlight selected findings for each city; Appendix Tables 1-6 contain detailed tables.

Readers who are interested only in an overview may wish to skip to the section on "Lessons." However, in doing so, they would miss fascinating stories of how individual cities have dealt with their economic problems.

\section{Springfield}

\section{Summary of challenges}

Known as the "City of Firsts," Springfield was for many years the center of a prosperous two-hundred-mile industrial corridor in the Connecticut River Valley. ${ }^{13}$ Unfortunately, the city has suffered a steep economic decline since the 1960s. The closures of the Springfield Armory ${ }^{14}$ in 1968 and the American Bosch metal fabrication factory ${ }^{15}$ in 1986 are just two examples of the

\footnotetext{
12 The crime rate is defined as total number of reported crimes per 1,000 population.

${ }^{13}$ Forrant (2009).

${ }^{14}$ The United States Congress had decided to locate the federal armory in Springfield in 1794.

${ }^{15}$ American Bosch opened in 1911 in Springfield's North End. When the factory closed, 1,500 jobs were eliminated.
} 
profound job losses in the city's manufacturing sector. While some manufacturing plants opened later on the outskirts of Springfield, these jobs are not as accessible to city residents.

Since the 1990s, the expansion in health care has filled some of the void produced by the departure of industrial jobs, but the city continues to struggle with identifying and attracting other potential sources of job growth within its borders. Springfield is home to several important institutions of higher education, but has not made as much progress as many of its peer cities in improving the educational attainment of its residents (Figure 5).

Springfield experienced a sharp decline in population from about 174,000 in 1960 to 152,000 in 1980. Since then, the number of residents has been relatively stable but their demographic composition continues to change. As noted earlier, in 2005-07, whites accounted for just over one-half of Springfield's population while Hispanics, the fastest-growing segment, represented one-third.

Abundant Victorian houses provide charm to Springfield, which bears the nickname "City of Homes." Sadly, a number of these houses are currently unoccupied: the overall residential vacancy rate rose to over 10 percent in 2005-07. ${ }^{16}$ Median family income and the poverty rate present a dire picture of the city, even when compared with other cities that have gone through similar deindustrialization processes.

In the past five years, Springfield has undertaken a number of local and regional initiatives to revitalize its downtown and attract new investment. These efforts provide hope of future economic progress.

\section{A struggling city with hopes of change}

With the opening of the Armory in the late $18^{\text {th }}$ century, Springfield became the heart of the metalworking manufacturing industry in the United States. Although signs of manufacturing decline were already visible in the 1960s, "defense spending during the Korean War rearmament boom and the Vietnam War allowed firms and workers to ignore their internal and external problems." ${ }^{17}$ During the latter half of the 1970s and in the 1980s, however, the city was hit hard. As manufacturing firms moved oversees and to Southern states, Springfield "hemorrhaged jobs at an alarming rate ... as 45 percent of the city's manufacturers closed." 18 The city was unable to redirect its manufacturing capabilities to other types of production (such as telecommunications and computer equipment) that allowed other Massachusetts cities to continue to prosper.

\footnotetext{
16 Although homeownership rates have been stable at around 50 percent, in the poorest area (Metro Center, Six Corners, and South End) homeownership rates were just 12 percent in 2000.

${ }^{17}$ Forrant, op. cit., p. 136.

${ }^{18}$ Forrant, op. cit., p. 32.
} 
The riverfront redevelopment projects of the 1980s-including the creation of the Basketball Hall of Fame and the renovation of the downtown civic center-proved unsuccessful in bringing the city back to its feet. By 1990, as the New England region was mired in a steep and prolonged recession and Springfield retailers continued to vacate their downtown locations, about one-quarter of downtown commercial space lay vacant. ${ }^{19}$ According to a recent account, corruption among public officials and the "failure of the region's extensive network of colleges and universities to contribute much time to strategizing over a solution to economic decline" $^{\prime 20}$ exacerbated the city's problems and "caused residents ... to become even more disenchanted with city leaders." 21 In the 1990s, "it seemed that the best economic development idea anyone could come up with for Springfield was casino gambling," 22 but the proposal was rejected by the city's residents. As the Urban Land Institute pointed out, "development projects floundered, and corruption crept into segments of the public sector. Neighborhoods seemed to turn inward rather than embracing the entire city and region." 23

In 2004, the dire condition of Springfield's finances prompted the state to appoint a Finance Control Board, ${ }^{24}$ which took over municipal spending decisions, focusing mainly on bringing expenditures into line with revenues. The Control Board also worked on strengthening the City's administrative capacity, in preparation for resuming normal municipal operations after the expiration of the Board's term in mid-2009.

\section{Positive steps}

Over the past decade, regional initiatives have become increasingly relevant in shaping development plans. In 2000, Springfield partnered with Hartford, Connecticut, to market the "Knowledge Corridor," a name reflecting the numerous colleges and universities in their vicinity. In 2004, the Pioneer Valley Planning Commission (PVPC) ${ }^{25}$ started overhauling the earlier Plan for Progress, a blueprint for growth and development of the regional economy. The plan established short-term and long-term milestones and promoted more collaboration among business and civic leaders. ${ }^{26}$

\footnotetext{
${ }^{19}$ Forrant, op. cit., p. 172.

${ }^{20}$ Forrant, op. cit., p. 168.

${ }^{21}$ Forrant, op. cit., p. 163.

22 "Paradise at a Price; The Economic Boom Has Mostly Skipped Western Massachusetts," Boston Globe, November 22, 1998.

${ }^{23}$ Urban Land Institute (2006).

24 The five-member control board was set up by the Massachusetts legislature and named by the Governor.

${ }^{25}$ Created in 1962, PVPC is a consortium of local governments in Hampden and Hampshire counties and is the regional planning body for the Pioneer Valley region.

26“20 Years of Economic Development: Taking a Regional Approach,” BusinessWest, June 1, 2004.
} 
Acknowledging their essential role in implementing workforce development programs and in creating and attracting businesses, educational institutions have become more active participants in economic renewal strategies. Springfield Technical Community College (STCC), in particular, has been a major contributor. ${ }^{27}$ The Entrepreneurial Institute at STCC, created in 1996, provides entrepreneurship education for students of all ages, ${ }^{28}$ and the STCC Technology Park has been successful in attracting tenants, incubating businesses, and providing technology training. ${ }^{29}$ The park's current plan calls for targeting companies in the biomanufacturing industry.

Springfield-based educational institutions such as Springfield College (SC) and American International College (AIC) are committed to the overall wellbeing of the city of Springfield and the neighborhoods where they are located. For example, both AIC and SC belong to the State Street Alliance, a large collaboration of institutions and residents overseeing the redevelopment of the major corridor running from downtown Springfield to points east. In 2009, the Carnegie Foundation for the Advancement of Teaching selected Springfield College as one of 119 U.S. institutions of higher learning to receive its Community Engagement classification. Springfield College was recognized for providing a curriculum that involves students and faculty in addressing community needs, and for outreach and partnerships that benefit both the community and the campus.

The University of Massachusetts has increased its involvement with the city in recent years. Scientists from UMass Amherst-only 27 miles from Springfield-have conducted joint projects with scientists at the Pioneer Valley Life Sciences Institute, a Springfield-based nonprofit organization dedicated to biomedical research. Researchers from the UMass Dartmouth campus are collaborating with the private nonprofit organization MassINC to develop a long-term growth strategy for the city with input from the government and the private and nonprofit sectors.

Based largely on a 2006 report by the Urban Land Institute, numerous revitalization projects are underway in the downtown area. Springfield's Union Station restoration is intended to transform the station into a multimodal transportation hub for both train and bus services. Various organizations with the support of the Massachusetts state government have

27 "Fueling the Region's Economy," BusinessWest, April 1, 2003.

${ }^{28}$ The institute focuses on all aspects of entrepreneurship education, ranging from a two-year associate degree to K-8 elementary entrepreneur programs and student business incubation.

${ }^{29}$ In 2001, STCC was selected by the U.S. Department of Commerce, Economic Development Administration as the sole national winner of the Award for Excellence in Urban Economic Development. 
come together to push for the restoration of rail service between Springfield and New Haven ${ }^{30}$ and, more generally, for improved connectivity and transportation access to Boston.

Most recently, five major employers have partnered with the city and with lenders to promote homeownership in Springfield. The "Buy Springfield Now" initiative is modeled on a program started in 2008 to provide homeownership incentives in Worcester.

Clearly, Springfield has intensified its economic development activities during the past several years. The degree to which the emergent revitalization efforts translate into higher employment and improved social indicators remains to be seen, particularly among the city's minority population. Furthermore, recession-induced fiscal pressures challenge city government as it reassumes the responsibilities temporarily ceded to the state-sponsored Control Board.

Each of the 10 resurgent cities has its own unique story of transformation. Following the individual accounts is a section that discusses some of the common themes and approaches.

\section{Evansville}

\section{Summary}

Evansville is located on the north bank of the Ohio River and historically has been an industrial and trade center for a large area in Indiana, Kentucky, and Illinois. Much has changed since the 1950s when the city was known as the "Refrigerator Capital of the World." In contrast with other manufacturing cities in the comparison group, Evansville began to diversify its economy relatively early. Although manufacturing continues to be an important component of Evansville's activities, the city has taken advantage of its strategic location and of improvements in transportation systems. As a result, Evansville has been successful in attracting new businesses, boosting tourism, and participating in international markets.

In 1960, Evansville ranked second to last among the 25 peer cities in median family income, but as of 2005-07 the city ranked eighth highest. The share of residents with at least a high school education increased by 43 percentage points from 1960 to 2005-07, the eighth largest improvement among the comparison cities over that period. On the other hand, the share of college graduates increased less than in the average peer city, and as of 2005-07 was below the comparison cities average. Contrary to most of its peer cities, Evansville has not experienced major changes in its racial and ethnic composition over the past half century. As of 2005-07, whites accounted for 86 percent of the city's residents (Figure 6), while Hispanics made up fewer than two percent.

\footnotetext{
${ }^{30}$ http://www.pvpc.org/corridor/history.html.
} 


\section{An ongoing transformation}

By the end of 1950s, Evansville was "gripped by a paralyzing economic slump." ${ }^{31}$ In 1959, the election of a new mayor who served 12 years in office marked the beginning of a series of initiatives that would sustain Evansville's economy. Mayor Frank F. McDonald II started by requesting a study about the city's potential, and personally contacted businesses to persuade them to settle in Evansville. During the 1960s, the city benefited from the construction of a civic center, federal buildings, a community center, the state's first enclosed mall, and the beginnings of downtown renewal. ${ }^{32}$

In the early 1980s, the Metropolitan Evansville Chamber of Commerce launched an aggressive economic development program that was successful in attracting large employers such as T. J. Maxx, which built a large redistribution center in the Evansville enterprise zone. ${ }^{33}$ By the late 1980s, the expansion of the Evansville airport and an extensive downtown revitalization were well along, and several industrial parks had opened.

The airport and the foreign-trade zone continued to attract businesses in the 1990s. Meanwhile, the University of Southern Indiana became the state's fastest-growing university, ${ }^{34}$ having spillover effects on housing construction and on commercial and retail trade. The aggressive strategy to attract businesses to the area achieved one of its major triumphs when a 4,400-employee Toyota truck plant opened close to Evansville in 1998. Tourism also has brought new employment to Evansville, particularly with the opening and renovation of large convention centers in the early 1990s and the Aztar riverboat casino in 1996, one of the city's largest employers.

Since the turn of the century, the city has paid particular attention to fostering growth in technology sectors. In 2006, Innovation Pointe, a not-for-profit organization that incubates small technological businesses, opened its doors. The University of Southern Indiana has partnered with Innovation Pointe by providing young companies with educational and training programs, student interns, and faculty mentors, and by holding some MBA classes in the facility.

\section{Working together}

Local economic development organizations and, later on, regional organizations have played an important role in targeting strategic sectors, attracting investment, and coordinating

31 “'McDonald Era' Lifted Evansville from Economic Slump," Evansville Courier, 150 Years of History series, January 8, 1995.

32 Ibid.

33 "Quality of Life: The Common Denominator in Southwest Indiana," Indiana Business, June 1985.

34 “Evansville: Cranes in the Air over Indiana's Third-largest City," Indiana Business Magazine, June 1, 2005. 
with local actors. The Evansville Regional Economic Development Corporation, ${ }^{35}$ for instance, has focused its activities on attracting new businesses, while retention and expansion activities have continued to be handled by the local Chamber. ${ }^{36}$

In recent years, the city has needed to reorganize several of its economic development institutions to avoid duplicating activities. In 2007, several organizations came together to form the Growth Alliance for Greater Evansville (GAGE), a public-private partnership focused on economic development. GAGE has formed a separate Downtown Development Division in addition to maintaining its broader focus on assisting businesses located in Evansville and Vanderburgh Counties. The city's commitment to attracting and retaining young professionals is evident in the networking opportunities provided through Young Evansville Professionals, chartered in 2001.

\section{Fort Wayne}

\section{Summary}

Fort Wayne, the second largest city in Indiana, "grew to become a city because of [its] location on key transportation routes - first water, then rail-and ... reached the pinnacle of economic success because [it was] one of the important manufacturing cities of the industrial Midwest." 37 Although Fort Wayne's economy developed later than the economies of the largest Midwestern cities, it ended up facing similar struggles as the rest of the so-called Rust Belt. ${ }^{38}$ However, from the crisis a strong sense of collaboration among various stakeholders emerged that allowed the city to recover and attract new businesses. The city has received the AllAmerican City award from the National League of Cities three times, most recently in 2009.

In certain respects, Fort Wayne has shown greater stability than other cities in the peer group. In the mid-2000s, nearly 20 percent of Fort Wayne's employed residents were still working in manufacturing (Figure 7). Although its median family income declined from 115 percent to 89 percent of U.S. median family income between 1960 and 2005-07, Fort Wayne has consistently had one of the highest income levels among the cities in the peer group. Fort Wayne's educational attainment has improved significantly over time, and has remained relatively high, particularly in terms of the high school completion rate, which reached 87

\footnotetext{
35 The corporation was previously known as Vision 2000, then as Vision-E.

36 "Economic Development: A Tale of LEDOs and REDOs," Indiana Business, May 1992.

${ }^{37}$ John Stafford, Director of the Community Research Institute at Indiana University-Perdue University Fort Wayne. "What Successful Cities Have to Say to Fort Wayne," speech given to the Quest Club of Fort Wayne in March 2006.

${ }_{38}$ As described by Teaford (1993), "During the decades following World War II urban Midwesterners faced the ugly symptoms of aging. By the 1950s, 1960s, and 1970s [large Midwestern cities] had turned gray, and at the beginning of the 1980s their feebleness was winning nationwide attention. They were the capitals of the rust belt, a decaying industrial swath that was no longer the nation's pride but instead had become a national problem."
} 
percent in 2005-07. From 1960 to the mid-2000s, Fort Wayne's population increased by more than 50 percent, mostly as a result of a strategy of growth through land annexation. ${ }^{39}$ The racial compositon of the city has not changed much over time, as whites still account for over threefourths of the population. The Hispanic share, while rising, remains low compared with the share in many other comparison cities.

\section{From crisis to recovery}

The economic recession of the early 1980s, a devastating flood in 1982, and the shutdown of International Harvester, the largest employer in the city, ruined Fort Wayne's economy. By 1983, the unemployment rate had increased to 14.5 percent, much higher than the national average. However, Fort Wayne managed to recover from the crisis sooner and more decisively than other Midwestern cities.

By the end of 1986, Fort Wayne had succeded in attracting large investments. General Motors started building a new \$500-million plant nearby; Burlington Air Express, the secondlargest air freight company in the United States, established its national hub in Fort Wayne; and large companies such as GE and ITT expanded their workforces in the city. ${ }^{40}$ Acknowledging that the city was concentrating much of its economic activity in the automotive industry, Fort Wayne financed a study in 1990 on ways to diversify its economy. Under the auspices of the Fort Wayne-Allen County Economic Development Alliance, founded in 1999, the city has adopted a long-term economic development strategy focused on seven sectors: advanced manufacturing (including vehicle production); agroprocessing (food and nonfood products); aerospace and non-aerospace airport-related development; communications and defense contracting; financial services; life and materials sciences; and logistics.

\section{"Wholehearted" economic development}

One of the main drivers of the city's success has been the collaboration between political parties, the private and public sectors, labor and community leaders, and citizens in general. Leadership from the Chamber of Commerce reportedly was important in attracting new businesses and strengthening partnerships with different stakeholders. ${ }^{41}$ Fort Wayne's efforts to attract businesses and "buy jobs" through low-interest financing, tax abatements, grants, and job training programs were not unique, but "Fort Wayne [did] it so wholeheartedly, and with such close cooperation between city officials and business, that the results [were] spectacular." 42

\footnotetext{
${ }^{39}$ From 1960 to 2000, Fort Wayne more than doubled its land area.

40 "A Rust Belt City Takes on a Shine," Fortune, November 10, 1986.

${ }^{41}$ Fortune noted that Ian M. Rolland, one of the most prominent Indiana business leaders, "led an effort to turn the moribund chamber of commerce into an aggressive, well-financed pursuer of new business." Ibid

${ }^{42}$ Ibid.
} 
MassINC portrays Fort Wayne as a success story in its study of Massachusetts gateway cities. ${ }^{43}$ The report points to two initiatives in particular. First is the introduction of "corporate style performance and accountability standards for all city operations" through a private sector program known as Six Sigma, a data-driven process for achieving quality that emphasizes speed, accuracy, and continuous evaluation of performance. ${ }^{44}$ Second is Fort Wayne's workforce development program that is "bridging the digital divide and fostering a culture of learning. The city is blanketing the entire municipality with a high-speed broadband network-a prerequisite for 'connecting' in the knowledge-based economy."

In light of continued employment declines in many of the Midwest's traditional manufacturing industries in the 2000s, Fort Wayne and other communities in northeast Indiana increasingly are emphasizing workforce development for technology-related job opportunities. The Northeast Indiana Innovation Center (NIIC), founded in the late 1990s and devoted to fostering high-tech entrepreneurship, relocated to a facility adjacent to Indiana UniversityPurdue University Fort Wayne (IPFW) in 2005 and opened a new "Emerging Growth Center" in 2008. As part of a recent $\$ 20$ million workforce development grant for northeast Indiana, the Indianapolis-based Lilly Foundation funded the creation of a wireless technology center at IPFW to prepare workers for defense-related jobs. ${ }^{45}$ The concentration of the NIIC facilities, the IPFW and IVY Tech campuses, and the Certified Technology Park designation ${ }^{46}$ form the basic elements around which an Allen County education-technology cluster is expected to emerge. Likewise, efforts such as the Young Leaders of Northeast Indiana provide a place for young professionals to network, to participate actively in the community, and to develop leadership skills.

Fort Wayne's 2009 All-American City award was based in part on the establishment of the Refugee Resource Center to provide services to the city's burgeoning immigrant and refugee population. Funded in part by a federal government grant, the Center helps new residents learn English and other skills, and gain access to health care and employment.

\footnotetext{
${ }^{43}$ The Massachusetts Institute for A New Commonwealth (2007).

${ }^{44}$ According to MassINC, in a short time, the city reduced water main replacement costs by 18 percent, cut pothole response time by 86 percent, and slashed the waiting time for building permits from 51 days to 12 days.

${ }^{45}$ http://homepages.indiana.edu/web/page/normal/10702.html and private communication with John Stafford, July 2009.

${ }^{46}$ Designation as a Certified Tech Park allows for the local recapture of certain state and local tax revenues which can then be invested in the development of the park.
} 


\section{Grand Rapids}

\section{Summary}

Grand Rapids is one of the most vibrant cities in the Midwest, the second largest city in Michigan, and the economic center of western Michigan. Once known as the "Furniture Capital of the World," Grand Rapids has diversified its economy both within and outside the manufacturing sector. These restructuring measures have been essential in sustaining economic growth and in providing flexibility during economic crises. The city's remarkable private sector philanthropy and public-private partnerships have played major roles in financing its redevelopment. To some extent, such institutions appear to have compensated for the lack of other potential financiers: in 2005-07, Grand Rapids had the lowest share of residents working in financial services of all the resurgent cities (Figure 8 and Tables 2 and 3). ${ }^{47}$

Grand Rapids has experienced considerable increases in population and educational attainment since 1960. The number of city residents rose considerably with the expansion of the city's land area between 1960 and 1980, and then increased another 6 percent from 1980 to 200507. Since 1960, Grand Rapids has consistently ranked among the top one-third of the peer cities in share of residents with a bachelor's degree. Currently, almost 27 percent of the adult residents of Grand Rapids have completed college. Notwithstanding the flow of new residents and the creation of new jobs, Grand Rapids has not managed to match the national trends in family income growth. Median family income in Grand Rapids has dropped from 107 percent of the U.S. average in 1960 to 75 percent in 2005-07.

The National Civic League recognized the city's qualities by selecting it as a finalist for the All-American City awards in 2003. The city's development plans were praised as rooted in community consensus. Thanks in large measure to private sector leadership and commitment, Grand Rapids has been able to combine the atmosphere of a small city with the advantages of a large metropolis.

\section{Private sector key in Grand Rapids' comeback}

In the late 1970s, Grand Rapids was in bad shape, as furniture manufacturing relocated to less expensive parts of the country, causing the city's unemployment rate to spike to nearly 17 percent. Fortunately, the city was able to reinvigorate its economy by adapting and diversifying.

\footnotetext{
${ }^{47}$ The next lowest share is found in New Haven, where Yale University has been a major funder of development projects.
} 
The furniture industry modernized itself by shifting from residential to commercial markets. Companies such as Meijer ${ }^{48}$ and Amway ${ }^{49}$ were retail industry pioneers in adapting to the new economy. As its automotive industry shrank, the city was able to attract companies such as GE Aviation Systems, an aerospace products company. The Grand Rapids economy continues to rely on small business ${ }^{50}$ and on firms that have grown but remain rooted in the city. As a result, the city was "one of the only manufacturing centers to grow during the 1990s." 51 The extent of diversification is visible in that the city's 10 largest employers represent nine industries, ${ }^{52}$ including health care, retail, insurance, office furniture, and automotive parts manufacturing.

Since the mid-1990s, Grand Rapids has worked to become a major player in the health care industry. The first significant step was the founding of the Van Andel Institute. ${ }^{53}$ In 1999, Grand Rapids' major health care providers joined forces with Michigan State University and Grand Valley State University to form the Medical Education and Research Center (GRMERC), a consortium integrating clinical research, medical education, and health professions education. A number of additional medical facilities and research institutions joined the Van Andel Institute and GRMERC to form the "Medical Mile."

\section{Development of physical and human capital}

Downtown redevelopment started with the creation of the Downtown Development Authority in 1979, and has been an important contributor to attracting younger adults and new businesses. Professionals increasingly see downtown as a desirable place to live. ${ }^{54}$ In just the past eight years, a new convention center, a sports arena, a medical institute, and a business college campus have been constructed in Grand Rapids. The success of downtown revitalization was made possible by public-private partnerships and donations from the private sector. ${ }^{55}$ Private investments have been viewed as providing risk-sharing and know-how to public projects. ${ }^{56}$ Even in the midst of the current economic recession, downtown Grand Rapids

\footnotetext{
48 In 1963, Meijer opened a food and general merchandise store in Grand Rapids, marking the birth of the supercenter, a concept that would grow into a retail phenomenon.

${ }^{49}$ Founded in 1958, Amway is a multilevel marketing business and direct seller of health and beauty products that now operates worldwide.

${ }^{50}$ Eighty percent of businesses in Grand Rapids employ fewer than 30 people. See Barone (1998).

51 Ibid.

${ }^{52}$ Ibid.

53 Jay Van Andel, one of the founders of Amway Corporation, founded the Van Andel Institute (VAI) in 1996. The Institute focuses its research on the genetic and molecular origins of cancer and other diseases.

54 "At Home Downtown; Young Professionals, Empty Nesters Flock to Condos", Grand Rapids Press, August 12, 2007.

55 "Minorities Demand Their Share of City's Prosperity; Grand Rapids Struggles with Diversity," Detroit News, June 13, 2001.

56 "A Tale of Two Cities; Two Similar Michigan Towns Have Taken Differing Paths," Grand Rapids Press, December 14, 2003.
} 
has continued to thrive thanks to "dedicated local developers" who have promoted "unprecedented investments in health care facilities." 57

Grand Rapids has benefited from working on long-term development plans and from coordination efforts across sectors. In 1992, the city launched "Voices \& Visions," a planning process that involves a wide range of actors from the Grand Rapids City Commission to the Grand Rapids Public Schools to the private sector. Links between the medical community and universities, in particular, have been widely recognized as essential contributors to revitalizing the downtown area. Retaining large employers has required coordinated efforts on the part of the city (through tax abatements), the Chamber of Commerce (through The Right Place planning programs) and training programs (provided by the Applied Technology Center). ${ }^{58}$ On several occasions, the city and the Chamber of Commerce have partnered with the Neighborhood Business Alliance (NBA) to work on economic development strategies. ${ }^{59}$ NBA is made up of representatives from all 20 neighborhood associations, meeting monthly to coordinate city-wide services, share best practices, and advocate on issues affecting neighborhood businesses and districts.

\section{Greensboro}

\section{Summary}

The economy of Greensboro, North Carolina's third largest city, used to center on the textile and furniture industries. As its manufacturing sector declined, the city shifted to new activities related to services and high-tech research and production. Although the textile and tobacco industries continue to be an important part of Greensboro's economic base, the city is "capitalizing on the growth in its new target sectors: advanced manufacturing, aviation, financial services and data centers, life sciences, and transportation and logistics." 60 Also, for most of the past three decades, the cities of Greensboro, Winston-Salem, and High Point-the so-called Piedmont Triad-have worked together on transportation, technology, and other economic development initiatives. These regional efforts have had positive impacts on Greensboro's economy.

\footnotetext{
57 “Downtown Stands Tall; Construction at Historic High Despite Recession," Grand Rapid Press, February 22, 2009.

58 The Right Place is a regional nonprofit economic development organization founded in 1985 and supported through investments from the private and public sectors. The Applied Technology Center is located on the Grand Rapids Community College downtown campus, and provides technical training and conference services. See "Business Retention Deemed Crucial to Downtown Hopes," Grand Rapids Business Journal, May 18, 1992.

59 “Ann Kassouni: Inside Track," Grand Rapids Business Journal, May 12, 1997.

60 “100 Best Places to Live and Launch," Fortune Small Business magazine, April 2008.
} 
Greensboro's population doubled between 1960 and 2005-07.61 Poverty rates remained low and fairly stable from 1980 to 2000; as a result Greensboro ended this two-decade period with the lowest population poverty rate among the peer cities. Although the poverty rate increased after 2000, it remained low relative to the rates in other peer cities. In terms of median family income, Greensboro has experienced significant progress relative to other peer cities. For the past half century, Greensboro has consistently had one of the highest rates of educational attainment among peer cities (Figure 9), and its shares of high school and college graduates are now above the national averages (Appendix Table 4)

Greensboro has promoted its attractive business climate and taken advantage of its central location in the South Atlantic region. In 2007, the city had the lowest cost of doing business according to the Forbes Magazine list of "Top 200 Places for Business and Careers," and in 2008 it was chosen among Fortune magazine's "100 Best Places to Live and Launch."

\section{Steps toward a more diversified economy}

As traditional manufacturing weakened, the city suffered but was able to diversify its economy towards high-tech manufacturing, financial services and insurance, aircraft maintenance, software design, and product distribution. ${ }^{62}$ The opening in 1982 of the Piedmont Triad International Airport terminal just west of Greensboro set off a building boom in the city. In 1986, American Express chose Greensboro over 25 competing cities as the location for a large service center; this was the biggest single employment expansion in the city since 1958. In 1987, the Nussbaum Center for Entrepreneurship opened its doors in an old mill building to support new or emerging nonretail businesses.

In the mid-1990s, the Greensboro business community developed a strategy to attract emerging high-tech companies, building on the experience of bringing in a new microchip manufacturing plant. ${ }^{63}$ By 2002 a "semiconductor cluster" of about 25 companies was thriving near Piedmont Triad International Airport. ${ }^{64}$ FedEx expects to complete construction of its MidAtlantic air cargo hub later this year, adding some 1,500 jobs at the airport.

Greensboro's educational network

The Greensboro News $\mathcal{E}$ Record recently noted that "universities are the primary players in a key group that includes the [Guilford Technical Community College (GTCC),] public

\footnotetext{
${ }^{61}$ Land area increased 115 percent from 1960 to 2000.

62 "Meet the Future Today," News E Record, January 26, 1997.

63 “Area Chamber Thinking High-tech," News E Record, September 8, 1996.

64 “The Pursuit of Knowledge; 2022: A Vision of Technology and Education," News E Record, June 8, 2002.
} 
schools and business that will form tighter bonds as Greensboro rebuilds, supplanting the old world dominated by businesses leaders who once met privately." 65

Parts of this educational network were already well established as of the 1990s. In 1996, the Wall Street Journal praised Greensboro Community College's job training curriculum, which was redesigned with the help of area businesses and prepares students to perform high-tech jobs in auto mechanics, textiles, and other industries.66 In addition, Guilford Technical Community College offers a Quick Jobs program that provides trainees with the basic skills required to find employment.

Also in the mid-1990s, business leaders joined forces with universities to foster hightech production, building on North Carolina A\&T State University's "cutting-edge research for federal agencies such as NASA" and on the University of North Carolina at Greensboro's (UNCG) "growing strength in the basic life sciences of biology and chemistry critical to such industries as pharmaceuticals." 67 North Carolina State University, UNCG, and the other schools in the region built the Triad Technology Center, becoming a "clearinghouse for research projects, fostering collaboration among the schools and companies seeking help in designing new products, testing them, or training workers." 68 In 2007, UNCG and North Carolina A\&T State University announced the creation of the joint research campus Gateway University Research Park and the Joint School of Nanoscience and Nanoengineering.

\section{Continuing adaptation}

A 2000 report by the private consulting firm McKinsey \& Company ${ }^{69}$ concluded that while Greensboro had enjoyed significant economic success over the past several decades and was well positioned among similar-sized cities in the Southeast, "the local economic base has shifted and growth will most likely slow over the coming years." Following the report's recommendations, a group of local charitable foundations created the not-for-profit organization Action Greensboro to coordinate the development-related activities of the city's numerous business and civic groups. ${ }^{70}$ Action Greensboro became a major player in development, investing in numerous projects-including parks, job recruitment programs, and downtown revitalization-and gauging the progress of the city.

\footnotetext{
65 "Rebuilding from Within; Knowledge, Innovation Form Base of Greensboro's New Economy," Greensboro News $\mathcal{E}$ Record, April 13, 2008.

66 "GTCC Aids Economy, Wall Street Journal Says," News \& Record, November 27, 1996.

67 "The Pursuit of Knowledge; 2022: a Vision of Technology and Education," News \& Record, June 8, 2002.

${ }^{68}$ Ibid.

${ }^{69}$ McKinsey discussion report (2000).

${ }^{70}$ In 2005 the Greensboro Partnership was formed to serve as an economic development umbrella, merging the board of directors of the Greensboro Chamber of Commerce and the Greensboro Economic Development Alliance.
} 
As anticipated in the McKinsey report, maintaining Greensboro's economic progress has proved harder in the 2000s. ${ }^{71}$ Referring to Greensboro as "relatively resilient" and "hardly a Rust Belt sob story," a local business publication noted that much of the city's recent job growth had been due to new retail and call center establishments that offered relatively low pay. ${ }^{72}$ To attract better jobs, Greensboro is looking at aerospace technology as a new engine for its economy. Honda Aircraft Company began building its new headquarters and R\&D and production facilities in Greensboro in 2007.

The city also has worked on downtown renewal. Since the renovation in 1998 of a 114year-old building - "the first thing that had been renovated downtown in 25 or 30 years" 73 - the rehabilitation of downtown has attracted business and residents. As of 2008, more than 1,200 people lived downtown, compared with only 500 four years earlier. ${ }^{74}$ Action Greensboro and Downtown Greensboro Inc. ${ }^{75}$ continue to be active in the economic development of the urban core.

\section{Jersey City}

\section{Summary}

Located on the west bank of the Hudson River across from Manhattan, Jersey City went from being a heavily industrial city in 1960 to a major financial center in the 2000s. In addition to Jersey City's proximity to New York City, transportation system improvements and business tax incentives encouraged a myriad of firms to locate in the city. The waterfront was revitalized, numerous high-rise buildings were constructed, and the population increased. As large financial corporations moved some of their activities to Jersey City, the city became one of the largest banking centers in the nation and received the moniker "Wall Street West." As of 200507, only 6 percent of the city's residents worked in manufacturing, the lowest share among the peer cities. The recent sharp slowdown in the nation's financial services sector and the prospect of regulatory reform add some uncertainty to the outlook for Jersey City's economic future, but

\footnotetext{
71 A 2003 report commissioned by Action Greensboro found that the city lagged similar Southeastern cities in education, health, and social services employment. See "Benchmarks put city in midpack of regional peers; Greensboro is developing an approach to better focus job recruitment," Greensboro News $\mathcal{E}$ Record, September 30, 2003. Four years later, yet another study concluded that a massive loss of manufacturing jobs since 2000 had been largely responsible for Greensboro falling behind some of its peers in average wage rates and growth in its tax base. See "Numbers improve, but Greensboro still lags peer cities," Business Journal, May 14, 2007.

72 "How Are We Doing?," Business Journal, August 27, 2004.

73 "Greensboro, Always Great for Business," US Airways Magazine, March 2008.

74 “Downtown Downturn?" News \& Record, December 31, 2008.

75 This is the official nonprofit organization focusing entirely on downtown and more specifically on the Business Improvement District (BID).
} 
the city is hoping to continue to take advantage of its relatively lower cost structure (as compared with New York City) in attracting businesses when the economy turns around.

Jersey City's economic transformation over the last five decades has been impressive. The city experienced the greatest improvement in educational attainment among the peer group cities, going from ranking second lowest in educational attainment in 1960 to ranking second highest in share of residents with a bachelor's degree and tenth highest with a high school diploma in the 2000s. Similarly, as of 2005-07, Jersey City had among the highest median family incomes of the comparison cities. While the majority of comparison cities and the United States as a whole experienced increased incidence of poverty, Jersey City's population poverty rate decreased in the last 30 years (Figure 10).

Jersey City is one of the most racially and ethnically diverse cities in the nation. As of 2005-07, whites accounted for only about one-third of Jersey City's population; AfricanAmericans constituted close to 30 percent; and many of the remaining residents were Asian. Slightly less than 30 percent of the total population of Jersey City was of Hispanic origin. Middle Easterners are prominent in Jersey City: along with the Detroit area and Paterson (NJ), Jersey City is among the top U.S. locations in the share of population that is of Arab ancestry. ${ }^{76}$

A study of 100 American cities by the Boston-based Initiative for a Competitive Inner City found that Jersey City had experienced one of the highest growth rates in inner-city small business jobs from 1995 to $2002 .{ }^{77}$ In comparison with the other "Big Six" urban centers in the state of New Jersey (Camden, Trenton, Paterson, Newark, and Elizabeth), The New York Times cited Jersey City as "the only one to experience a true renaissance."78

\section{From manufacturing city to "Wall Street West"}

During the pre-World War II era, Jersey City was a thriving manufacturing center with an efficient transportation system and an active waterfront. However, in the 1950s the economy started to stumble, as the manufacturing sector declined and railroad tracks were abandoned. Private-sector employment plummeted more than 20 percent from 1950 to 1975, ${ }^{79}$ and continued to drop until the early-1980s. Job and population declines were accompanied by corruption scandals and soaring crime rates.

\footnotetext{
76 This information is drawn from a variety of sources that differ somewhat in their definitions of the Arab population. According to the 2000 Census, Arabs were one of 33 ancestry groups with a U.S. population of over 1 million. See U.S. Census Bureau, “The Arab Population: 2000," Census 2000 Brief, issued December 2003.

77 Initiative for a Competitive Inner City (ICIC) (2005).

78 "A City Whose Time Has Come Again; After Years of Deprivation, Jersey City, an Old Industrial Powerhouse, Is Remaking Itself," New York Times, April 30, 2000.

${ }^{79}$ http://www.jcedc.org/Pages/25-52economic.pdf.
} 
The first areas to be revitalized were the ones "most ravaged by poverty and decay during the decades after World War II." 80 The mid-1980s construction on abandoned waterfront property of the Newport Development, a $\$ 2.5$-billion mixed-use community, is widely credited with kicking off Jersey City redevelopment. Except for recessionary periods in the early 1990s and late 2000s, high-rise buildings continued to spread, and financial and other professional services jobs continued to increase.

Investors were attracted to Jersey City because of its proximity to New York City and its relative affordability compared with the skyrocketing real estate costs in Manhattan. However, the city arguably would not have become "the crown jewel of development" 81 or attracted large financial services companies (including Merrill Lynch, Goldman Sachs, and Morgan Stanley) had it not also worked on providing good infrastructure, reducing crime and corruption, and offering business tax incentives.

Since the early twentieth century Jersey City has been connected to Manhattan through the PATH train system. Ferries and several bus services also have provided easy access to New York City. In the early 2000s, the transportation system was improved further with the construction of a $\$ 2.2$ billion light rail system aimed at relieving the increasing congestion along the Hudson River waterfront.

From the mid-1990s to 2006, robberies and murders dropped by over 35 percent in Jersey City. ${ }^{82}$ Although the city had become known for corruption, after former Mayor Gerald McCann was indicted in 1991, "the systematic graft that had characterized doing business in Jersey City decreased dramatically." 83 Although Jersey City's transformation began with McCann, his successor, Mayor Bret Schundler, is praised for being "largely responsible for the metamorphosis of the urban center into today's dynamic metropolis." 84

In 1987, about one-third of Jersey City was designated by the state of New Jersey as an Urban Enterprise Zone (UEZ), ${ }^{85}$ to be administered by the Jersey City Economic Development Corporation (JCED), a nonprofit organization that functions as a liaison between developers and the city. In addition to the sales tax incentives offered through the UEZ Program, the city took advantage of state Business Employment Incentive Program (BEIP) grants. Because the size of these grants was determined by the amount of the employer's income tax withholdings

80 "Stepping Out of Manhattan's Shadow," New York Times, November 21, 2004.

81 "Hot Spots for Development," New Jersey Business, March 2008.

82 "Jersey City Grows, But Not Everywhere," Associated Press Newswires, March 4, 2006.

83"A Tale of Two Cities," NJBIZ, August 26, 2002.

84“Jersey City: America's Golden Door," New Jersey Business, January 1, 1999.

${ }^{85}$ State tax revenues generated by UEZ businesses are dedicated to economic development projects within the zone. Businesses participating in the UEZ Program are allowed to charge one-half the standard sales tax rate on certain purchases. 
for new hires, the program was especially attractive for businesses locating high-paying jobs in New Jersey. ${ }^{86}$

\section{Economic development away from the waterfront}

In the first wave of "corporate migration" 87 to Jersey City, prosperity did not spread beyond the waterfront into the inland neighborhoods where most city residents live. ${ }^{88}$ But over the past decade, Jersey City has begun to see development of "the new middle-class housing, name-brand retail stores, trendy restaurants, and galleries needed to lure new residents and provide jobs for existing ones." ${ }^{99}$ The city issued over 2,000 residential building permits in 2004, up from only about 300 a decade earlier. ${ }^{90}$ Neighborhoods are working with the city in implementing their own economic development projects. Residents of one of Jersey City's poorest neighborhoods, the Martin Luther King Drive, not only participated actively in writing their development plan, but also controlled its implementation, through a neighborhood development corporation (NDC). The plan received national and statewide awards and recognition for its innovative use of community outreach and implementation. ${ }^{91}$

A remaining challenge is improving the public school system. Like schools in many other densely populated urban areas, Jersey City schools have "a history of being strained by overcrowding, underfunding, high dropout rates and a multitude of other problems faced by districts that serve large numbers of disadvantaged children." ${ }^{92}$

\section{New Haven}

\section{Summary}

New Haven, Connecticut's third largest city and home to Yale University, has struggled during the past 50 years, as have most old manufacturing cities. However, the city has shown signs of economic transformation since the early 1990s, when Yale began to take an active role in local development. Close to 40 percent of employed New Haven residents work in the education, health care, and social assistance sectors (Figure 11), and the biomedical sector has emerged as a growing driver of the city's economy.

\footnotetext{
${ }^{86}$ See http://www.state.nj.us/njbusiness/financing/incentive/beip_brrag.shtml.

${ }^{87 " H}$ How Wall Street West Was Won - Jersey City Emerges as One of the Nation's Hottest Real Estate Markets," Star-

Ledger Newark, September 17, 2000.

88 Ibid.

${ }^{89}$ Ibid.

90 “Jersey City Grows, But Not Everywhere," Associated Press Newswires, March 4, 2006.

${ }^{91}$ http://www.smartgrowthgateway.org/case_mlk.shtml.

92 "Stepping Out of Manhattan's Shadow," New York Times, November 21, 2004.
} 
One of New Haven's major strengths is its highly educated population. The share of college graduates in the adult population was 31 percent in 2005-07, above the national average and 10 percentage points higher than the average of comparison cities. In the 2000s, population and relative median family income have finally begun to reverse the declining trends experienced since the 1960 s.

New Haven has attempted to balance its efforts at economic development with policies to provide affordable housing for residents of modest means. The Housing Authority of the City of New Haven is committed to subsidizing 30 percent of all rental units in the city. ${ }^{93}$ Not surprisingly, therefore, the poverty rate in New Haven remains high-24 percent in 2005-07. And despite the sharp reduction in overall crime from 1975 to 2000, New Haven's violent crime rate is the highest among the resurgent cities.

New Haven's racial and ethnic composition has changed dramatically in the past half century. Whites accounted for 85 percent of the city's population in 1960, but make up less than one-half today. In 2005-07, New Haven was 37 percent black and 24 percent Hispanic.

Yale University's changing role

During the early 1980s, the industrial base of New Haven continued to erode, as major manufacturers closed factories or reduced employment. These developments were similar to those of other old industrial cities around the country, but they contrasted with the experience of other Connecticut urban areas where employment was increasing. ${ }^{94}$ In addition, although Yale had always played a major role in New Haven, the university tended to isolate itself from the city's economic troubles. Real estate developer and gubernatorial candidate Joel Schiavone commented, "Yale did what Yale does best: retreat inside its walls and lock its doors."95

City economic development officials, corporations, and Yale University joined efforts for the first time in the mid-1980s to try to enhance New Haven's service-sector employment. One result was "New Haven 1990," a marketing proposal that grew out of conversations among development, business, and neighborhood representatives, and with experts from other cities that had undertaken similar initiatives. ${ }^{96}$

\footnotetext{
${ }^{93}$ www.hud.gov/offices/pih/programs/ph/mtw/newhaven.cfm.

${ }^{94}$ As noted in the New York Times article "New Haven Planning Science Park to Stem Job Losses," July 20, 1980, “ In Stamford, employment continued to grow rapidly in corporate headquarters. Bridgeport's metalworking companies were operating at full capacity, and new capital was flowing into primary metals plants in Waterbury. Insurance and finance companies were hiring steadily in Hartford, precipitating construction."

95 “Focusing on Private Redevelopment, Not Public Urban Renewal," Washington Post, October 29, 1989

96 These cities included Baltimore, Boston, and Indianapolis.
} 
In 1991, Yale reached a formal agreement with the city that "some have viewed as historic." 97 The University agreed to pay the city $\$ 1.2$ million a year (an amount equivalent to over 5 percent of the municipal budget) in recognition of fire protection services, and to put its golf course on the property tax rolls (yielding about $\$ 350,000$ a year in tax revenue). Under the agreement, Yale also agreed to spend \$50,000 annually for five years to fund "The Center for the City," an organization aimed at tapping business, government, and other resources to attack the city's social problems. Yale's initiatives also included funding the following: \$12.25 million to redevelop four deteriorating blocks in the city's retail center; investment in a face-lift for the Broadway shopping strip; \$5 million to create a venture capital fund aimed at luring biotechnology companies to the Science Park incubator; $\$ 2,000$ a year offered for 10 years to any Yale employee who buys a house in the city; and the resources to renovate four vacant storefronts on Park Street to house a Yale police substation and several student programs. ${ }^{98}$ In short, a major historical account of the city noted, "Few major initiatives on any front-public education, neighborhood development, arts and culture, downtown commerce-would fail to attract Yale's comment or concern in the 1990s." 99

By the mid-1990s, New Haven's economy seemed to be on a firmer footing. Biomedical industry and other projects developed in the city, accompanied by an "explosion of interest in the city's art and music scene and the infusion of ambitious new immigrants, which ... boosted the city's cosmopolitan appeal."100

In partnership with Yale University and the business community, the city of New Haven launched an Economic Development Corporation in February 2008. A primary mission of this organization is to operate as a one-stop center to attract new businesses and to retain existing businesses.

\section{Continuing challenges in spreading opportunity}

A continuing theme in New Haven is the need to spread the benefits of economic resurgence to more neighborhoods and members of the community. Despite Yale's continued involvement, its success and interest in alleviating New Haven's most serious social problems have been called into question. Historian Douglas Rae has pointed out that Yale "[has] produce[d] no miracles in public education, and most of its faculty [have] express[ed] little if any enthusiasm for solving urban problems." 101

\footnotetext{
97 “Elm City Bows Under Urban Pressures," Business Journal-Hartford, January 28, 1991.

98 These initiatives were promoted by Richard C. Levin, a Yale economist who lived in New Haven for 23 years and became the university's president in 1993.

${ }^{99}$ Rae (2003) p. 431.

100" New Haven Has an Attitude, a New One," New York Times October 23, 1994.

${ }^{101}$ Rae, op. cit.
} 
One set of recent initiatives concerns life sciences education. Local universities and businesses are working with the city's public schools to develop curricula and materials, and to provide teacher training related to biotechnology. The state of Connecticut recently matched $\$ 1.5$ million in funding provided by private biotechnology and pharmaceutical companies for the "Biobus," a state-of-the-art mobile laboratory that takes biotechnology education on the road." ${ }^{102}$

Other efforts relate to supporting small and minority-owned businesses. The city's Small Business Initiative (SBI), established in 1999, provides loans, façade grants, technical assistance, and shelter market construction opportunities. ${ }^{103}$ The Small Business Enterprise Construction Opportunity Initiative, approved in 2001, states the city's preference to do business with small business contractors. In addition, school construction projects are required to employ small contractors for at least 10 percent of the construction value of all new school construction. Similarly, the City of New Haven's Commission on Equal Opportunity administers a local ordinance intended to increase minority, female, and apprentice work at federal, state and cityassisted job sites.

\section{Peoria}

\section{Summary}

One of the oldest communities in Illinois, Peoria is located along the Illinois River in the largely agricultural area between Chicago and St. Louis. Peoria has long been seen as the prototypical American city and thus has been used as a test market for products, services, and public opinion polling. Throughout much of the 20th century, the city developed as a "classic one-company town" with Caterpillar as its economic engine. Even though Caterpillar remains the area's single largest employer and 16 percent of city residents continue to work in the manufacturing sector, Peoria has shifted gears towards becoming a more technology-based economy.

Peoria was the only city in the peer group to experience rising median family income relative to the U.S. median during the period 1960 to 1980 (Figure 12). After 1980, Peoria's median family income eroded for awhile, but then eventually stabilized in the 2000s. As of 2005-07, Peoria had the second highest median family income among the peer cities, as well as the second lowest poverty rate. Peoria also showed one of the largest improvements in educational attainment among the comparison cities from 1960 to the mid-2000s.

\footnotetext{
102 http://www.cityofnewhaven.com/economicdevelopment/pdfs/officialStatement07.pdf.

${ }^{103}$ http://www.cityofnewhaven.com/smallbusiness/LoanProgram.asp.
} 


\section{The transformation of a one-company town: Phase I}

Created through the merger of two farm tractor companies in the early 20th century, Caterpillar expanded to become the world's largest manufacturer of construction and mining equipment, diesel and natural gas engines, and industrial gas turbines. Acknowledging that further diversification was needed to sustain Peoria's economy, a group of civic leaders created the Economic Development Council for the Peoria Area (EDC) in 1981. The EDC attracted new companies to the area, helped retain existing companies, and worked to ensure that the entire region was involved in economic development strategies. ${ }^{104}$ After going through rough times during the recessions of the early 1980s, community leaders, Peoria's mayor, and the private sector (including Caterpillar) joined forces to strengthen the EDC. Mayor Jim Maloof, elected in 1985, was characterized as "a very effective force [who] came at a time Peoria needed to rebuild its community psyche." 105

Growth in the retail and service sectors reduced Peoria's dependence on Caterpillar to some extent, but the firm continued to be the main driver of economic activity in the 1990s. ${ }^{106}$ Local commentators pointed to a number of obstacles to executing development projects and attracting businesses to Peoria. According to a newspaper account from the early 1990s, the city still relied on "an 'archaic' long-term economic development plan from the 1970s." 107 Some developers complained about City Hall's bureaucracy and stringent building standards. A former member of the Downtown Redevelopment Commission mentioned that "part of the problem with the city's previous plans has been an inability to turn them into reality." 108 One of the leaders of riverfront development blamed "a lack of continuing strong, intelligent and decisive leadership in both the public and private sectors." ${ }^{109}$

\section{Accelerated progress in Peoria}

Fortunately, the turn of the century brought forth local and regional initiatives that accelerated Peoria's economic transformation. In 2001, the associate dean of the University of Illinois College of Medicine led an effort on the part of local medical centers, universities, and

104 "Development Group Changes with Times[:] EDC Has Led Efforts to Attract, Retain Jobs During Past 15 Years," Peoria Journal Star, July 7, 1996.

105 Ibid.

106 “Make No Mistake About It: This is a Caterpillar Town," Peoria Journal Star, September 28, 2002.

107 "A Hotly Competitive Future; If Peoria Wobbles, Smaller Communities Will Pick Up the Economic Pieces," Peoria Journal Star, July 24, 1991.

108 "Should Peoria Dust Off Those Old Plans? - As the City Debates What Should Be Done with the Marriott Hotel Space, Some Local Leaders Encourage a Look Toward the Past," Peoria Journal Star, March 29, 2009.

${ }^{109}$ Ibid. 
the National Center for Agricultural Utilization Research ${ }^{110}$ to develop a bioscience strategy that would build on the various institutions' expertise. ${ }^{111}$ The following year, Caterpillar and other local businesses and civic leaders formed a membership organization called Peoria Next to promote technology-centered development for the city. Through activities such as networking meetings and business incubation, Peoria Next has built up a "knowledge community network" to foster and sustain an intellectual creative class. ${ }^{112}$ One early mark of success, growing out of research conducted at Caterpillar, was the founding of battery developer Firefly Energy Inc., co-winner of the 2007 Wall Street Journal Technology Innovation Award.

In 2003, the Peoria City Council passed an ordinance creating the 773-acre Peoria Medical and Technology District. A commission of representatives from the neighborhoods, businesses, and anchor institutions (Bradley University, Methodist Medical Center, OSF Saint Francis Medical Center, the University of Illinois College of Medicine at Peoria, and the National Center for Agricultural Utilization Research) developed a comprehensive master plan for the Med-Tech District, naming it "Renaissance Park." As a result of the many new medical infrastructure and research facilities being built in the district, Peoria is gaining recognition as a "major medical powerhouse."113 Aside from health care facilities, other large downtown projects in the 2000s have included a new museum complex, ${ }^{114}$ renovation and expansion of the Peoria Civic Center, and an upgrade to the zoo. ${ }^{115}$

Two major projects are improving Peoria's transportation infrastructure, which had become a major source of concern for manufacturers and distributors. The state's $\$ 460$ million overhaul of Interstate 74 provided Peoria better highway system access, and the construction of a new terminal at the Peoria International Airport is expected to be completed in 2010. In an effort to coordinate resources and develop regional strategies, various economic development organizations formed the Heartland Partnership, ${ }^{116}$ which provides a forum for identifying

110 The National Center for Agricultural Utilization Research is the largest of the four U.S. Department of Agriculture regional research labs.

111“Will It Play? As the Loss of Manufacturing Jobs Continues to Corrode the Local Economy, Peoria Is Turning to High-Tech R\&D Startups to Polish its Rust Belt Image," Crain's Chicago Business, December 8, 2003.

112 “Make No Mistake About It: This Is a Caterpillar Town," Peoria Journal Star, September 28, 2002.

${ }_{113}$ "Powerful Medicine - Local Health-Care Community Continues to Take Economy to New Heights," Peoria Journal Star, October 14, 2006.

114 The $\$ 100$ million Museum Square is a joint venture between Lakeview Museum and its partners, and Caterpillar. 115 “On Fertile Ground - New Faces See Peoria Turning Corner,” Peoria Journal Star, January 25, 2004.

116 The partners are Heartland Capital Network, Peoria Next, EDC, Peoria Area Chamber of Commerce, and the Illinois Regional Port District. 
regional issues and recommending actions to be considered by the Economic Development Council for Central Illinois and the Peoria Area Chamber of Commerce. ${ }^{117}$

Peoria relies on long-term planning to sustain its success. The Peoria Civic Federation, primarily comprised of the leaders of the region's largest employers, sponsored the Greater Peoria Vision 2020, which was released in 2005 after a two-year planning process. Several community councils oversee the implementation of various regional master plan areas such as quality of life, economic revitalization, youth and education, and leadership. In 2009, the city of Peoria sought community input on the updated Comprehensive Plan, ${ }^{118}$ which develops an overall vision for Peoria's growth and development over the next 10 to 20 years.

\section{Providence}

\section{Summary}

Historically, Rhode Island's capital, Providence, was an important manufacturing and textile center, and was known as the capital of the jewelry making industry in the United States. After World War II, the city fell into a downward spiral, losing population and jobs. As mills closed and retailers moved to the suburbs, organized crime and corruption became entrenched in the city. The poor condition of Providence's finances prevented the city from taking part in the sorts of revitalization programs that many cities around the country undertook during the 1970s. Fortunately, starting in the early 1980s, a series of major rehabilitation projects transformed Providence, enabling its successful promotion as the "Renaissance City." The downtown area was renovated, attracting residents, artists, and visitors.

The population of Providence had started to shrink in the 1940s. The city experienced particularly heavy population losses from 1960 to 1980 as some 50,000 more residents left the city than migrated in. Providence's rehabilitation projects and a large influx of Hispanics finally reversed the declining population trend. The city, known for its Irish and Italian heritage, was 36 percent Hispanic as of 2005-07 (Figure 13).

The Renaissance City has made considerable improvements in educational attainment, both in absolute terms and relative to comparison cities. The share of the adult population with at least a high school education has more than doubled in the last 50 years, while the share that finished college increased from below 7 percent in 1960 to 29 percent in 2005-07. When ranked by share of college graduates, Providence improved from 12th among the comparison cities in 1960 to sixth in 2005-07. Despite these successes, the city still faces significant challenges, chiefly concerning poverty and diversity issues.

117 http://www.heartlandpartnership.org/.

118 Peoria began the process of rewriting its Comprehensive Plan in March 2007, the first complete rewrite since 1991. 


\section{The rebirth of Providence}

Sharp employment declines in the textile industry and the relocation of retailers in the 1960s produced further deterioration in Providence's economy, which had been struggling since the 1940s. As factories closed and population fled the city, construction came almost to a halt. One study notes "the only major building program undertaken by the city in the 1950s and the 1960s was the construction of seven low-income housing projects ... and housing facilities for the elderly."119

In 1974, Vincent Cianci was elected as mayor. Although controversial, Cianci brought energy and a strong presence to the city and led Providence to carry out ambitious projects. During Cianci's first decade in office, tax breaks, federal investment, and collaboration with the business sector resulted in the construction of new hotels, the restoration of Union Station, and the renovation of movie theaters.

In 1975, the Providence Foundation, a nonprofit organization comprising the chief executive officers and top managers of some of the region's leading businesses, was formed to "create, plan and facilitate feasible downtown development projects." 120 Thanks to the Foundation, important downtown projects (the Civic Center, the Majestic Theater, and two hospitals) were executed in the 1970s. After Cianci left office, ${ }^{121}$ the private sector-led by the Providence Foundation, the Greater Providence Chamber of Commerce, and corporate leaders - was instrumental in pursuing development initiatives. ${ }^{122}$

Two projects started in the early 1990s were essential in reconnecting downtown to the rest of the city and in developing the waterfront, which is at the core of Providence's attractions. With the support of federal funding, railroad tracks running through the downtown area were relocated underground. In addition, the two rivers that cross the city came back to life thanks to the removal of the "widest bridge of the world" that had covered them for 50 years.

Cianci was reelected as mayor in the mid-1990s, and he worked to establish tax incentives to attract artists to live downtown and a loan program to help in launching restaurants. ${ }^{123}$ The creation of the arts and entertainment district in 1996 was the lynchpin in the cultural revival of the city. ${ }^{124}$ Providence's success became "the talk of America's urban planners and cultural observers, its virtues touted ... on the front page of USA Today, and in an essay on

\footnotetext{
119 Orr and West (2002).

${ }^{120}$ Leazes and Motte (2004).

${ }^{121}$ In 1984, Cianci resigned after facing assault charges.

122 Marrion and West, op. cit., p. 404.

${ }^{123}$ Marrion and West, op. cit., p. 406.

124 "Success of R.I. Arts District Encourages Plans in Md.; Incentives for Artists Also Boost Economy," Baltimore Sun, May 19, 2001.
} 
architecture in the New York Times."125 More recent projects in the downtown area have included the construction of a new convention center and the Providence Place shopping mall. The relocation of route 195, scheduled to be completed by 2012, will add more space to downtown and improve the city's transportation system. ${ }^{126}$

\section{Alliances with foundations and nonprofits}

Providence has benefited from collaborative and flexible relationships with foundations and nonprofits. Using a revolving-loan fund dedicated to economic revival, mixed-income housing, and an expanded arts district, the Rhode Island Foundation contributed \$9 million in 2001 for the creation of the Downcity Partnership Inc., aimed at reviving Providence's downtown. ${ }^{127}$ The Providence Foundation and the City of Providence were partners in the initiative. In 2004, the Downcity Partnership program was transferred to the Providence Revolving Fund, a community-based, nonprofit lending corporation established in 1980. The Revolving Fund's resources are targeted to specific historic neighborhoods and primarily serve low-to-moderate income families.

Community development corporations (CDCs) and other nonprofit organizations have spearheaded housing, education, and training programs that serve as complements to commercial redevelopment. Thanks to CDCs, "the city's supply of affordable and decent housing seems to be growing." 128 The New York headquartered Local Initiatives Support Corporation (LISC) selected Providence as one of six demonstration sites ${ }^{129}$ for neighborhood revitalization programs with the participation of local CDCs, the city, and the community. The Providence Plan, a not-for-profit joint venture of the City of Providence, the State of Rhode Island, the academic community, and the private sector, focuses on children's well-being, workforce development, and community building. Its successful programs include Ready to Learn Providence, YouthBuild Providence, and the Local Learning Partnership. In 1997, the Pew Partnership for Civic Change selected Providence as one of 10 cities to participate in the Pew Civic Entrepreneur Initiative, a nationwide project to train a diverse group of citizens to play a greater role in decision-making in their communities. ${ }^{130}$

In summary, Providence has been able to build on its numerous assets, including its riverfront, historic buildings, and prestigious educational institutions-Brown University, the Rhode Island School of Design, and Johnson and Wales University's famous culinary institute.

\footnotetext{
125 “What Rhode Island Needs Now," Providence Journal, August 24, 1999.

${ }^{126}$ The relocation will open access to more than 60 acres of land for riverfront development.

127 “Diamond Next to the Rough," Providence Journal-Bulletin, August 12, 2001

128 "Conversation with Barbara Karlin, Advocate for Neighborhoods," Providence Journal-Bulletin, April 18, 2000.

129 The other five sites are Indianapolis, Milwaukee, the Twin Cities, the Bay Area, and Washington, DC.

130 The Pew Partnership invited applications from more than 70 cities with populations between 150,000 and 450,000.
} 
The city has become a tourist destination and a trendy place to live. ${ }^{131}$ However, challenges remain. Most jobs created by the retail, accommodation, and arts and entertainment industries are in low-wage occupations; Providence's distressed neighborhoods have not benefited fully from the city's renaissance; and the fraction of the population living in poverty remains quite high. The city also is challenged by the need to provide adequate services to the rapidly increasing minority population. According to the American Community Survey, nearly half of Providence residents speak a language other than English at home. Of these foreign-language speakers, one-third consider their English language skills to be poor.

\section{Winston-Salem}

\section{Summary}

Winston-Salem, long recognized for its tobacco industry, is now known internationally for high tech and for being a pioneer in improving connectivity throughout the city. After Winston-Salem suffered a wave of job losses in the 1980s, universities and public-private partnerships contributed to the development of new industries. Regional alliances have been a central part of the city's development, as Winston-Salem works closely with Greensboro and High Point to draw businesses and support start-ups.

In 2004, Winston-Salem was selected by Partners for Livable Communities ${ }^{132}$ as one of the 30 "Most Livable Communities," based on its "creativity and ability to prepare for the new economy."133 Winston-Salem was also named one of the world's "Most Intelligent Communities" in 2008, in a list drawn up by the Intelligent Community Forum. ${ }^{134}$ In 2006, the city was included among "America's 50 Hottest Cities" for business relocation or expansion, 135 and in 2009 Forbes Magazine ranked the Winston-Salem metropolitan area as the 18th best place in the United States for business and careers.

Winston-Salem's land area has more than tripled and its population almost doubled since 1960. Median family income as a share of the national average fell less than the shares of the other comparison cities, and Winston-Salem's educational attainment has remained among the highest when compared with similar cities (Figure 14).

131 “Smaller Is Better in New Urban Revival," USA TODAY, August 16, 1999.

132 Founded in 1977, Partners for Livable Communities is a nonprofit leadership organization that promotes quality of life, economic development, and social equity.

133 “Recent Award Recognizes City's Achievements," Winston-Salem Journal, May 29, 2004.

${ }^{134}$ For a city to be on the list, it has to excel in one of the following factors: broadband connectivity, knowledge workforce, digital inclusion, innovation, and marketing and advocacy.

135 Expansion Management magazine asked over 80 prominent site location consultants to list their top city choices for relocating and expanding companies, taking into consideration such factors as the business climate, work force quality, operating costs, incentive programs, and ease of working with local political and economic development officials. 


\section{From tobacco to high-tech}

The tobacco industry has gone through a deep transformation over the past two decades, as has Winston-Salem's economy. Declining cigarette consumption and market competition ${ }^{136}$ have adversely affected the R. J. Reynolds Tobacco Company (RJR), producer of the famous Camel cigarettes and formerly Winston-Salem's largest employer. In the late 1980s, Winston-Salem suffered a series of employment losses as some of its major employers closed, went bankrupt, or relocated. ${ }^{137}$ These job losses motivated the creation in 1987 of Winston-Salem Business Inc. (WSBI), an economic development nonprofit organization that has been recruiting new businesses to Winston-Salem and Forsyth County. Since its formation, WSBI has assisted over 110 companies that together brought more than 10,000 jobs to the target area.

In 1991, the Winston-Salem Chamber of Commerce developed the Blueprint for Technology, which included initiatives for K-12 public education. ${ }^{138}$ The Blueprint shifted the city's business focus from traditional manufacturing to technology-based activities. In 1995, the Piedmont Triad Research Park (PTRP), an urban-based, mixed-use technology research park, was inaugurated in downtown Winston-Salem. Among the park's earliest occupants were the Wake Forest University Health Sciences Department of Physiology and Pharmacology and a team of researchers from Winston-Salem State University.

In the mid-1990s, Wake Forest University began to work on a plan to connect its medical school and undergraduate campuses with a high-speed network. ${ }^{139}$ Together, the university, the Winston-Salem Chamber of Commerce, local government, and other institutions pursued projects to improve the city's connectivity. The process resulted in the creation in 1997 of WinstonNet, ${ }^{140}$ a nonprofit community technology initiative whose goal is "bridging the digital divide." Thanks to various public and private partnerships including Wireless Winston, Idealliance, and the Piedmont Triad Entrepreneurial Network, nearly 90 percent of households in Winston-Salem subscribed to broadband as of 2008. ${ }^{141}$

By the late 1990s, Winston-Salem was better prepared to face job losses when R.J. Reynolds Tobacco announced further layoffs and U.S. Airways closed its local maintenance

136 "Changing Times; A Dynamic Decade in the Triad," News E Record, July 17, 1995.

${ }^{137}$ Reynolds Tobacco's parent company, RJR Nabisco, moved its headquarters from Winston-Salem to Atlanta; AT\&T shut down its local operations; and McLean Trucking Company filed for bankruptcy.

138 The Chamber of Commerce contracts with the local school system to provide business partners that connect the work world with the education world. The Chamber has also established a 42-member Education Business Council to engage the business community in increasing the high school graduation rate in the Winston-Salem schools.

139 http://www.intelligentcommunity.org.

140 http://www.winstonnet.org/about/history.html.

${ }^{141} \mathrm{http}$ //www.intelligentcommunity.org. 
center. $^{142}$ Rising employment in health care and banking had offset many of the ongoing losses of tobacco-related jobs. ${ }^{143}$ The university-affiliated hospital surpassed RJR as the city's largest employer and, as the home of two large regional banks, Winston-Salem became the 11th-largest banking center in the country, just behind Boston.

Major business openings and expansions in the 2000s have included a Dell plant, ${ }^{144}$ a U.S. Airways call center, and the Pepsi Customer Service Center. ${ }^{145}$ Local media reports attributed these successes in part to city and state tax incentives and workforce training offered by Forsyth Technical Community College. ${ }^{146}$ To help support smaller business development, the Winston Works task force, formed by the Chamber of Commerce, launched a campaign to encourage companies to dedicate at least one percent of their discretionary spending to local suppliers. ${ }^{147}$

\section{Reviving Winston-Salem's downtown area}

The city has intensified its focus on downtown revitalization in recent years. In 2002, the Winston-Salem Alliance, a private economic-development group, announced plans to invest $\$ 40$ million in downtown development projects, and Wake Forest University revealed plans to expand its Piedmont Triad Research Park. ${ }^{148}$ The Downtown Winston-Salem Partnership, a member and advocacy organization, is the lead organization implementing the Downtown Plan developed in 2007. Part of the revitalization plan includes the Restaurant Row Program, ${ }^{149}$ introduced by the city with federal and state support to help recruit and finance new eateries. The plan also calls for promoting Winston-Salem as the "City of the Arts"150 and for attracting businesses in the design industry.

142 "Forsyth Looks Beyond RJR Cuts; a Healthy Economy Should Help the County to Take the Layoffs in Stride Say Business People," Greensboro News E Record, December 15, 1998.

${ }^{143}$ Between 1988 and 1998, R.J. Reynolds' share of the city taxes levy dropped from 18 percent to 6 percent, and the size of its local workforce fell by half. See The Economist (1999).

${ }^{144}$ Lobbying by more than 100 Triad officials persuaded the General Assembly to provide more than $\$ 200,000$ in incentives for each job created at the Dell plant. "We've Got Dell: Alliance Site Best Suited to Plant's Timetable, Company Says; Local Officials Celebrate End of a 'Very Aggressive' Pursuit; Hiring Is Expected to Begin in April; Assembly Plant Could Have 1,500 Workers in 5 Years," Winston-Salem Journal, December 23, 2004.

145 The Chamber helped form a Regional Call Center Group where representatives of many of the Triad's call centers meet to discuss issues and concerns and to work together on finding employees and solve other common problems.

146 “Triad Keeps US Airways Call Center Jobs, to Gain 300 More," Triangle Business Journal, Wednesday, January 26, 2005.

147 “Increase Local Purchases, Businesses Urged; 'Don't Pass the Buck' Drive Meant to Aid Triad Economy," WinstonSalem Journal, February 14, 2004.

148 "A Shot in the Arm; Downtown Renewal to Get \$39.5 Million Boost from Private Development Group," WinstonSalem Journal, November 22, 2002.

149 http://www.dwsp.org/development_projects/restaurant_row.php.

150 “Going Forward with Arts Center Sends Right Signal for the Future," Winston-Salem Journal, February 15, 2009. 


\section{Worcester}

\section{Summary}

As the third largest city in New England ${ }^{151}$ and geographically the closest resurgent city to Springfield, Worcester historically has been a major industrial center and a transportation hub, but has also struggled to acquire its own identity independent of Boston. Worcester missed the economic boom that some other cities in Massachusetts experienced in 1980s. Fortunately, the city was able to reposition itself as an important center for the biotechnology industry by the 1990s. With its 11 colleges and universities and major transportation improvements, the "City of the Seven Hills" has been able to attract new businesses and to make progress on reversing its earlier population declines.

Worcester's accomplishments have gained nationwide recognition. The city won the National Civic League All-American city award in 2000 after a long hiatus. In 2008, Worcester ranked 38th among Fortune Small Businesses" "100 Best Places to Live and Launch, "152 and in 2009 the Worcester metropolitan statistical area was selected as one of Forbes' most livable cities.

Worcester has done better than the average comparison city in terms of improving educational attainment. The share of population with a college degree or more jumped from only 7 percent in 1960, similar to the comparison group average, to 28 percent in 2005-07, seven percentage points higher than average. In addition, Worcester went from having the fifth highest crime rate in 1975 to tied (with New Haven) for the fifth lowest in 2007 (Figure 15 and Appendix Table 6).

\section{From manufacturing to life sciences}

Worcester had many planned development projects in the 1980s that were supposed to represent the largest investments in the city since World War II. However, with the exception of a few important projects, including the Centrum and the Massachusetts Biotechnology Research Park, most expectations were unfulfilled. ${ }^{153}$ A lack of leadership among local officials and difficulties in obtaining financing have been widely cited as two of the factors responsible for the missed opportunities of the 1980s.

151 Worcester had historically been the second largest city in New England, but the 2000 Census showed that Providence's population exceeded that of Worcester.

152 The ranking is based on indicators that include tax rates, job growth, number of parks and arts venues, health infrastructure, average temperatures, percentage of startups, population growth, crime rates, and housing costs, as well as interviews with entrepreneurs, local officials, and business experts.

${ }^{153}$ A Business Worcester article commented that "more than a half-dozen major projects were proposed for Downtown Worcester in the mid-1980s. Not one has been built yet. Some will never be built." "Downtown Worcester: Missed Opportunities," December 25, 1989. 
The creation of the Massachusetts Biotechnology Research Park, home of the Massachusetts Biotechnology Research Institute (MBRI), was the beginning of the biotechnology era in Worcester. The center has been characterized as "perhaps the most successful biotech real estate development in the nation." ${ }^{154}$ A Boston Globe article noted that the MBRI "model of a public-private partnership and grass-roots support to create companies and jobs is being adopted as far away as Scotland and as nearby as Maryland." 155 The Chamber of Commerce and the University of Massachusetts Medical Center ${ }^{156}$ played key roles in forming the MBRI back in 1984. The MBRI, the strong educational base of the city, ${ }^{157}$ and low living costs relative to those in the Boston area attracted biotech firms to the Worcester area.

Despite the biotechnology industry boom, the city had to readapt its development approach because biotech companies often employ only small numbers of workers and take a long time to achieve profitability. In 1998, the MBRI changed its name to Massachusetts Biomedical Initiatives, as it launched efforts to attract medical devices companies that could become an important source of jobs.

\section{Missteps as well as successes}

In the mid-1990s, Worcester launched a marketing campaign to change its "old mill city" image. At the same time, thanks to the partnership between various governmental entities, the city started the renovation of Union Station, which had been shuttered for three decades. Eventually, frequent commuter rail service was established between Worcester and Boston. Another transformative transportation project, begun in 1995, was the building of a limitedaccess connector road that gave the city direct access to the Massachusetts Turnpike in 2007.158

Some of the city's other investment initiatives begun in the 1990s have been less successful. The 1996 expansion of the airport which "had been an off-and-on operation ever since it opened in 1946"159 has failed to live up to its promise. The construction of Worcester Common Outlets mall in the downtown area was a misstep as well. The outlet mall opened in 1994, replacing another mall that had been in disuse for a decade. However, most retailers left within just a few years of its opening.

154 “Worcester's Mass. Biotech Park Starts Building," MASS HIGH TECH, November 30, 1992.

155 "High Tech to Biotech in Roxbury; Former Digital Plant to House Laboratories; Emerging Business," Boston Globe, August 7, 1994.

156 The medical school was funded in 1962 and became one of the top schools in the country.

157 Higher education institutions include UMass Medical School, Worcester Polytechnic Institute, Clark University, College of the Holy Cross, and the Tufts University Veterinary School, among others.

${ }^{158}$ For more detailed discussion of the significance of these transportation projects, see Worcester Regional Research Bureau, Inc (2008).

159 Southwick (1998). 
Worcester has continued to engage in significant economic development programs in the 2000s. The Massachusetts College of Pharmacy and Health Sciences located its Worcester campus downtown in 2005. The city is working on yet another project in the Common Outlets location-this time, a mixed-use development with retail, office, entertainment, and housing space. The nonprofit organization Choose Worcester, founded in 2007, aims to attract new businesses and help businesses that are already in the city to grow.

\section{Wide-ranging roles for colleges and universities}

Finally, although universities have long been an important asset to Worcester, they have become more closely integrated with the city's economic development during the last decade. The UniverCity Partnership was formed in 2005 to adopt strategies allowing higher education institutions to participate in economic growth by improving local purchasing, employment, real estate development, business incubation, and workforce development. ${ }^{160}$ Among its current efforts, the city is looking to attract more technology firms through the Worcester Polytechnic Institute (WPI) Venture Forum.

Universities also have become engaged in community projects. For instance, WPI has worked with the Worcester Business Development Corporation on turning useless brownfields into attractive, multi-purpose landscapes. The University Park Partnership (UPP), the result of long-standing collaboration between Clark University and its surrounding community, focuses on neighborhood revitalization. ${ }^{161}$

\section{Lessons from the Resurgent Cities}

As these accounts illustrate, city resurgence can take place regardless of the region of the country or composition of the population. Some cities in the Northeast and Midwest have made noteworthy recoveries from declines in manufacturing, while other cities in the same and adjacent states have not. The successes have included places such as Fort Wayne and Evansville with low minority shares, but also places such as Jersey City, New Haven, and Providence where-as in Springfield-non-Hispanic whites make up less than one-half of the total population. ${ }^{162}$ Fewer resurgent city residents are employed in manufacturing than in the past, but manufacturing continues to account for between 6 percent (Jersey City) and 20 percent (Fort Wayne) of city resident employment. In many of the resurgent cities-especially those along the

160 “Town-Gown Partners Are Ready to Move," Worcester Telegram E Gazette, April 10, 2005.

${ }^{161}$ Clark students and faculty work and conduct research for UPP organizations, such as the Main South CDC. In addition, many faculty and staff-including Clark's current president-have become neighborhood residents.

162 In 2000, Jersey City ranked among the ten highest cities and Fort Wayne among the 10 lowest cities nationally in terms of minority population share (defined according to individuals who classified themselves as Hispanic, a race other than white, or both). See Berube (2003). Another study in the same volume notes that Greensboro and Providence were among the 18 "'hypergrowth new Latino destinations." See Suro and Singer (2003). 
East Coast-both the health care sector and the education sector are important sources of jobs for city residents.

These patterns suggest that Springfield faces no inherently insurmountable barriers to resurgence. Nonetheless, to be relatively successful among its peer group, Springfield needs a major focus on improving employment opportunities for city residents so as to raise their incomes and reduce the incidence of poverty. To accomplish these objectives, Springfield must remove barriers that prevent city residents from filling job openings and must attract more jobs to the city and to parts of the surrounding area that are accessible to city residents.

While the stories from cities with higher incomes and lower poverty rates than Springfield's vary in some respects, they share common elements that provide useful lessons to nonresurgent cities. Most notably, they illustrate that resurgence requires decades of sustained, collaborative efforts on the part of governments, business groups, and nonprofit institutions. It also requires the ability to imagine radical changes to the city and its economy-as well as continued refinements - to ensure that important objectives are being met even as economic conditions change. A successful transition to a knowledge-based economy requires considerable focus on human capital-both building up the skills of residents and attracting and retaining well-educated newcomers. Finally, some of the cities with sizeable minority populations have decided in recent years to increase their focus on initiatives related to public schools, affordable housing, and small businesses. Others appear likely to take steps along these same lines in an effort to spread the benefits of their economic progress.

\section{Leadership and collaboration}

The stories of resurgence involve leadership on the part of key institutions or individuals, as well as collaboration among the various constituencies with an interest in economic development. In these success stories, the instigators of city revitalization recognized that it was in their own interest to prevent further deterioration in the local economy. They started by taking responsibility for bringing about improvement. Collaboration became necessary because economic transformation is complex, and because outsiders - such as state and national governments, foundations, and businesses that are potential sources of new jobsoften require proof of joint efforts in order to contribute to the city's development.

In the cases of Evansville and Providence, the turnarounds could be traced to municipal economic development initiatives in the early to mid-1960s. In both cases, however, energetic city mayors implemented their visions with the support of outside resources. In Evansville the Chamber of Commerce worked aggressively to attract large employers, and in Providence a nonprofit foundation worked together with business executives to gain consensus on 
downtown development projects. For both cities, the ongoing commitments of business and nonprofit groups provided critical continuity when new mayors came into office.

Resurgent cities have actively promoted themselves. Although institutional arrangements have varied across cities and over time, the more successful cities now typically have a private, nonprofit organization heading economic development efforts. Such organizations collaborate closely with local Chambers of Commerce and other nongovernmental entities, but they have broader mandates. Economic development organizations have institutionalized relationships with city government, usually in the form of funding and representation on the board of directors. The Fort Wayne-Allen County Economic Development Alliance, which provides assistance to companies seeking to locate or expand operations in Fort Wayne or Allen County, includes a city and a county employee working inhouse.

Institutions of higher education have often played key roles in city resurgence. As noted, New Haven's redevelopment came about only after Yale University joined a city marketing effort in the 1980s. Yale's subsequent involvement with New Haven has taken various other forms, including making substantial payments in lieu of property taxes, renovating universityowned downtown commercial properties, providing venture funding for biotechnology, offering incentives to induce employees to purchase homes in the city, and financing efforts to attack the city's social and educational problems. Worcester, on the other hand, is an example of a city with many colleges and universities, but no single dominant institution. There, a special partnership was formed in the mid-2000s to provide the city's colleges and universities roles and responsibilities in local economic development. In addition to the kinds of involvement that Yale has had in New Haven, selected Worcester institutions have found unique ways to contribute to the community. These have included locating new campuses in the downtown area, working on brownfield remediation, and providing their expertise to community organizations.

Many of the resurgent cities have also tapped into grant monies on the local and national levels. Grand Rapids and Providence have benefited greatly from nearby private philanthropies. Providence also has reached out to out-of-region nonprofits to help with affordable housing and diversity initiatives. In addition to the examples noted for the individual cities, other sources indicate that a number of national foundations focus on the types of problems that the comparison group cities have in common. For instance, a recent study points to "the Kauffman Foundation's support of entrepreneurs and new businesses, the Annie E. Casey Foundation's focus on how economic and workforce development affects the well-being of children and families, the Surdna Foundation's new work on 'weak-market' cities, 
and the Charles Stewart Mott Foundation's interest in sectoral workforce and economic development strategies." 163

The resurgent cities offer examples on how to coordinate with regional and neighborhood players. Unlike the situation in New England, counties in the Midwest and South are important governmental entities, and regional efforts are the norm there. Nonetheless, regional economic development organizations have sometimes carved out specific bodies to focus on city concerns. For example, the Growth Alliance for Greater Evansville formed a separate Downtown Development Division. Similarly, Greensboro had long benefited from collaboration with the other cities in the Piedmont Triad, but in 2001 formed a nonprofit organization to coordinate the economic development efforts of the city's business and civic groups. In Grand Rapids, the Neighborhood Business Alliance works with the Chamber of Commerce on economic development strategies. A Jersey City development corporation operating in one of the city's poorest areas has received national recognition for involving the community in implementing economic planning.

\section{Recreating city infrastructure and economies}

Like Springfield, all of the cities under review had locational advantages that made them prosper in the industrial era. Many were well located for both water and rail transportation, which proved important in getting delivery of raw materials and in supplying finished goods to market. Over the course of the last several decades, the resurgent cities have focused on modernizing their transportation and communications infrastructures by expanding regional airports, improving roads, and building high-speed broadband networks. Such infrastructure improvements have been important draws for both manufacturing and nonmanufacturing firms. Providence offers perhaps the most dramatic example of infrastructure makeovers to reconnect the downtown area with the rest of the city and to redevelop the waterfront area.

The stories of resurgence involve more than modernizing infrastructure and industries. Some cities not only built on their traditional strengths, but also succeeded in creating business clusters virtually from scratch. For example, Grand Rapids set out in the 1990s to become a major center for health care in an initiative that has resulted in the creation of medical facilities and research institutions to form the "Medical Mile." Likewise, Peoria decided to focus on health care and medical technology and is now gaining recognition as a "major medical powerhouse." Winston-Salem, once known internationally only for tobacco, chose to emphasize Internet connectivity and has gained renown for creativity and intelligence. Jersey City built up a finance cluster starting from a 1960 base that was not much larger than Springfield's. In

163 See McGahey and Vey (2008). pp. 22-23. 
hindsight, this growth strategy for Jersey City may seem obvious, given its proximity to New York City. However, another nearby city in the comparison group, Paterson, did not seize its similar locational advantage.

The resurgent cities have also illustrated the need to adapt to changing circumstances. In some cases, a given development strategy proved successful in some respects, but not others. For example, working with the Chamber of Commerce and the University of Massachusetts, Worcester established the Massachusetts Biotechnology Research Institute to attract biotech companies. The city later broadened its focus to include medical devices companies so as to increase the job-creation potential of its life sciences cluster. In other cases, development projects had to be scrapped or radically overhauled. Worcester abandoned a failed shopping mall in favor of a mixed-use project that includes office and residential space.

Another striking feature of resurgent cities' stories is the need for continuing innovations in overall development strategy. In the 1980s, Fort Wayne adapted to the shutdown of its largest employer by attracting investments on the part of other large companies. More recently, however, the city's focus has been on becoming a stronger player in high-tech entrepreneurship. Greensboro succeeded in attracting service jobs, but is now actively recruiting higher paying employers. Peoria realized in the 1990s that building up its retail and service sectors was insufficient to bring about the desired rate of economic growth. The city turned to new strategies centered on medical research, technology, and entrepreneurship.

\section{Developing human capital}

During the 1980s and 1990s, "buying jobs" was a key part of economic development activities in the resurgent cities. For example, Fort Wayne aggressively used low-interest financing and tax abatements to attract new business activity. To the present day, Jersey City benefits from state tax incentives, and Greensboro competes in part based on its low cost of doing business relative to other cities in the nation.

With the continued transition to a knowledge-based economy, development strategies increasingly have emphasized improvements to human capital. As the resurgent cities demonstrate, institutions of higher education can play a broader role beyond educating students in degree and certificate programs. Greensboro offers the most comprehensive role model among the comparison cities. There, community colleges provide courses related to fundamental job skills, and universities partner with businesses in developing innovative products and skills related to areas such as pharmaceuticals and nanotechnology. Another useful model is New Haven, where local universities, private industry, and state government have collaborated to disseminate biotech-related education in the public schools by providing teacher training, assistance in curriculum design, and a mobile laboratory facility. 
Another aspect of developing human capital is attracting talent. As noted, employersponsored home buying programs have been used in New Haven and Worcester, and Springfield recently launched such an initiative. Other examples include efforts to appeal to young professionals and entrepreneurs, such as the networking organizations that exist in Peoria and Worcester, and the vibrant arts district in Providence.

\section{Extending prosperity to disadvantaged and minority neighborhoods}

Despite their overall successes, the resurgent cities continue to struggle with extending prosperity to a broader share of their populations. Except for Fort Wayne, all had poverty rates exceeding 17 percent as of 2005-07. In fact, poverty remains more prevalent in Providence and New Haven than in a half-dozen of the cities in the nonresurgent list (Akron, Allentown, Bridgeport, Rockford, South Bend, and Waterbury).

Some of the resurgent cities have implemented distinct efforts to improve opportunities for their poor and minority residents, and to narrow the differences between the haves and the have-nots. Although they are separate initiatives, these programs often adopt approaches similar to those used to generate prosperity more generally. Most importantly, they involve collaborations. As noted, The Providence Plan to promote children's well-being, workforce development, and community building is a joint venture of the City of Providence, the State of Rhode Island, the academic community, and local businesses. In Jersey City, the success of economic development plans in poor neighborhoods that were not benefiting from the riverfront area boom required community involvement in shaping local economic plans and controlling their implementation.

\section{Next Steps for Springfield}

No research study is capable of laying out the agenda for Springfield. This one has attempted to lay out reasonable aspirations for the city, and to add to the available information concerning the economic development approaches tried by Springfield's peer cities.

On the one hand, the message is a positive one. Nothing about Springfield's past or present industry mix, demographic composition, or geography prevents the city from becoming as successful as the 10 resurgent cities that started in similar circumstances a half century ago.

On the other hand, this report aims to challenge Springfield's various constituencies. The hope is that they will compare their actions with those taken by their counterparts in other cities and, in doing so, will come up with some fresh ideas about how to deal with lingering challenges. Rather than ending with recommendations, therefore, the study offers Springfield residents, businesses, city government, and other organizations the following discussion questions in connection with the case studies from resurgent peer cities: 
- How might the lessons from the resurgent cities be adapted to suit Springfield's situation?

- What specific local groups might collaborate or form to promote and implement the revitalization of Springfield?

- What similar economic development efforts have been tried in Springfield?

o For those that have had some success, how could they be improved or expanded?

o For those that have had limited success or have fizzled, what prevented the achievement of their goals?

- Have the efforts made on behalf of the revitalization of Springfield aimed high enough, and have they had the support they needed?

- Which economic development efforts from the resurgent cities have not been tried in Springfield?

o Which are worth further consideration?

o What is the most promising action plan?

- What next steps should individuals or groups who are inspired by the successes of the resurgent cities take to re-energize Springfield's economy and community? 


\section{References}

Barone, Michael. 1998. "A City Where Business and Philanthropy Flourish." American Enterprise 9(5).

Berube, Alan. 2003. "Racial and Ethnic Change in the Nation's Largest Cities." In Redefining Urban \& Suburban America: Evidence from Census 2000, Volume 1, ed. Bruce J. Katz and Robert E. Lang. Washington DC: Brookings Institution Press.

Browne, Lynn, and DeAnna Green with Marques Benton, Prabal Chakrabarti, Yolanda Kodrzycki, Ana Patricia Muñoz, David Plasse, and Richard Walker. 2009. "Towards a More Prosperous Springfield, Massachusetts: Project Introduction and Motivation." Federal Reserve Bank of Boston Community Affairs Discussion Paper No. 01. Boston: Federal Reserve Bank of Boston. Available at http://www.bos.frb.org/commdev/pcadp/2009/pcadp0901.pdf

De la Cruz, Patricia, and Angela Brittingham. 2003. “The Arab Population: 2000." Census 2000 Brief. Washington, DC: U.S. Census Bureau.

Forrant, Robert. 2009. Metal Fatigue: American Bosch and the Demise of Metalworking in the Connecticut River Valley. New York: Baywood Publishing Company.

Fox, Radhika, and Miriam Axel-Lute. 2008. "To Be Strong Again: Renewing the Promise in Smaller Industrial Cities." PolicyLink. Available at https://www.policyarchive.org/bitstream/handle/10207/13689/ToBeStrongAgain.pdf?sequence= $\underline{2}$.

Furdell, Kimberly, and Harold Wolman. 2006. "Toward Understanding Urban Pathology: Creating a Typology of 'Weak Market' Cities." George Washington Institute of Public Policy Working Paper No. 021. Washington, DC: The George Washington University.

Available at http://www.gwu.edu/ gwipp/papers/wp021.pdf.

Initiative for a Competitive Inner City (ICIC). 2005. "State of the Inner City Economies: Small Businesses in the Inner City." Washington, DC: The Office of Advocacy of the U.S. Small Business Administration. Available at http://www.sba.gov/advo/research/rs260tot.pdf.

Kneebone, Elizabeth. 2009. “Job Sprawl Revisited: The Changing Geography of Metropolitan Employment." Metropolitan Policy Program at Brookings. Washington, DC: The Brookings Institution. Available at http://www.brookings.edu/ /media/Files/rc/reports/2009/0406 job sprawl kneebone/20090406 jobsprawl kneebone.pdf.

Leazes, Francis J., and Mark T. Motte. 2004. Providence, the Renaissance City. Boston: Northeastern University Press.

McGahey, Richard M. 2008. "Regional Economic Development in Theory and Practice." In Retooling for Growth: Building a 21'st Century Economy in America's Older Industrial Areas, ed. 
Richard M. McGahey and Jennifer S. Vey, 3-31. Washington, DC: Brookings Institution Press. Available at

http://www.brookings.edu/ /media/Files/Press/Books/2008/retoolingforgrowth/retoolingforgro wth chapter.pdf.

McKinsey \& Company discussion report. 2000. "Building Consensus for Greensboro's Future." Available at

http://www.actiongreensboro.org/reports/McKinsey1.pdf.

Mieszkowski, Peter, and Edwin S. Mills. 1993. "The Causes of Metropolitan Suburbanization." Journal of Economic Perspectives 7(3): 135-147.

Muro, Mark, John Schneider, David Warren, Eric McLean-Shinaman, Rebecca Sohmer, Benjamin Forman, with Dana Ansel and Greg Leiserson. 2007. "Reconnecting Massachusetts Gateway Cities: Lessons Learned and an Agenda for Renewal." Boston: Massachusetts Institute for a New Commonwealth. Available at http://www.massinc.org/fileadmin/researchreports/gateway cities/gateway cities full.pdf.

Orr, Marion, and Darrell M. West. 2002. "Citizens' Views on Urban Revitalization: The Case of Providence, Rhode Island." Urban Affairs Review 37(3): 397-419.

Rae, Douglas. 2003. City: Urbanism and Its End. New Haven, CT: Yale University Press.

Southwick, Albert B. 1998. 150 Years of Worcester: 1948-1998. Worcester, MA: Chandler House Press.

Suro, Roberto, and Audrey Singer. 2003. "Changing Patterns of Latino Growth in Metropolitan America." In Redefining Urban \& Suburban America: Evidence from Census 2000, ed. Bruce J. Katz and Robert E. Lang, 181-210. Washington DC: Brookings Institution Press.

Teaford, Jon C. 1993. Cities of the Heartland. The Rise and Fall of the Industrial Midwest. Bloomington: Indiana University Press.

Urban Land Institute. 2006. "Springfield Massachusetts, Strategies for a Sustainable City." Washington, DC: Urban Land Institute. Available at http://www.springfieldcityhall.com/COS/fileadmin/reports/SpringfieldMA06v6_lores.pdf.

Wolman, Harold, Edward W. Hill, and Kimberly Furdell. 2000. "Evaluating the Success of Urban Success Stories: Is Reputation a Guide to Best Practice?" Housing Policy Debate 15(4): 965997.

Worcester Regional Research Bureau. 2008. “What's Up with Downtown Worcester? Prospects for Revitalization." Report 08-08. Worcester, MA: The Worcester Regional Research Bureau. Available at http://www.wrrb.org/documents/WRRB-08-08.pdf. 


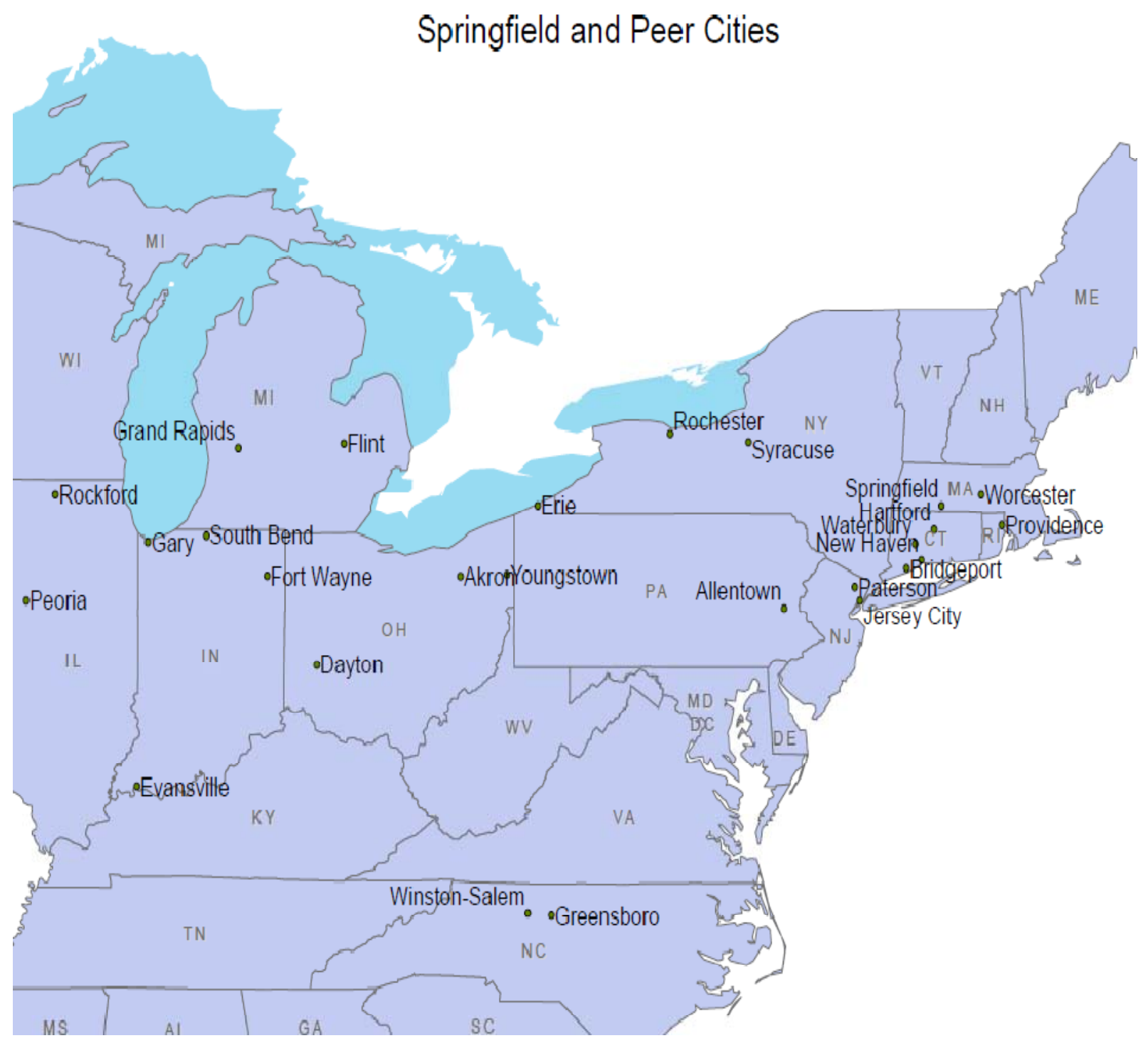


Figure 2

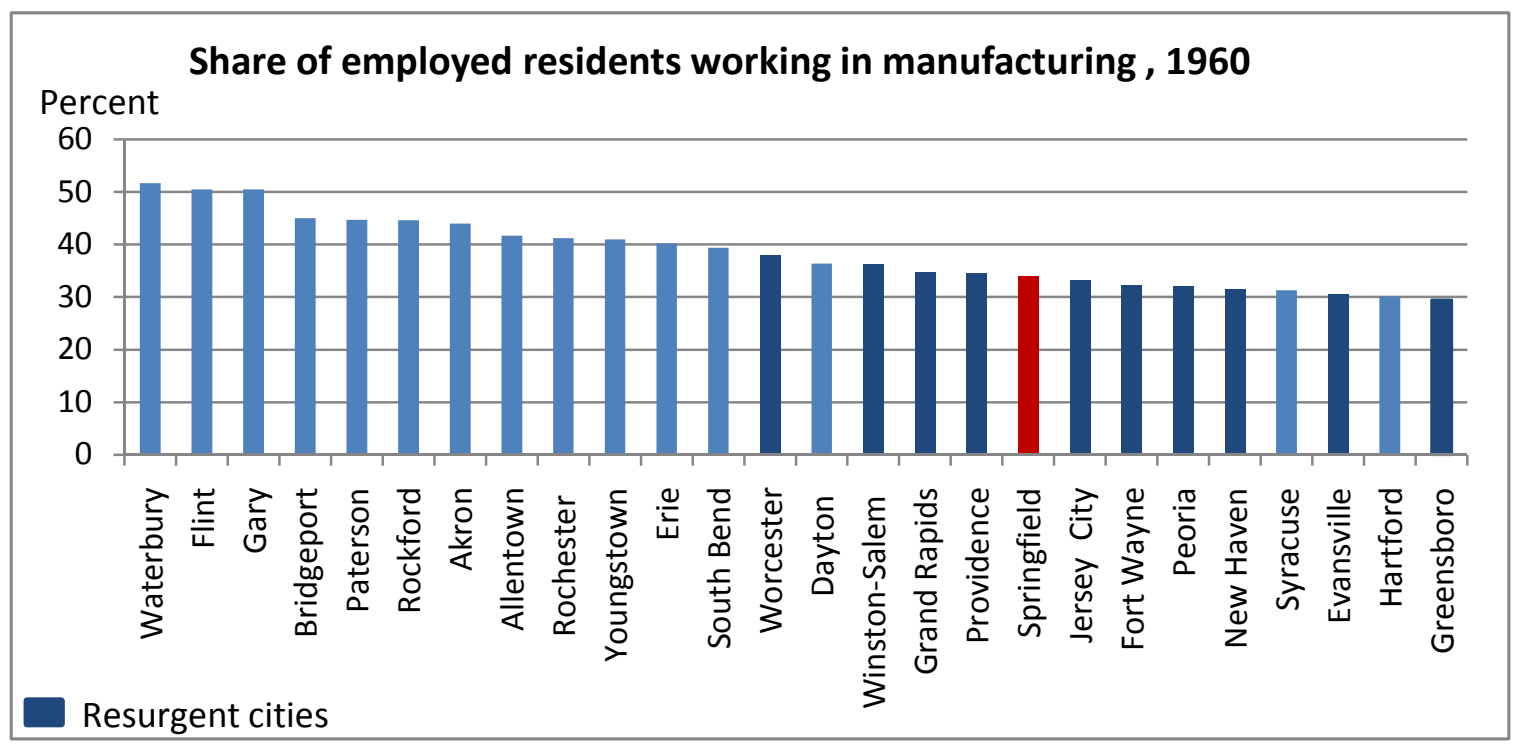

Source: U.S. Bureau of the Census. County and City Data Book (1960).

Figure 3

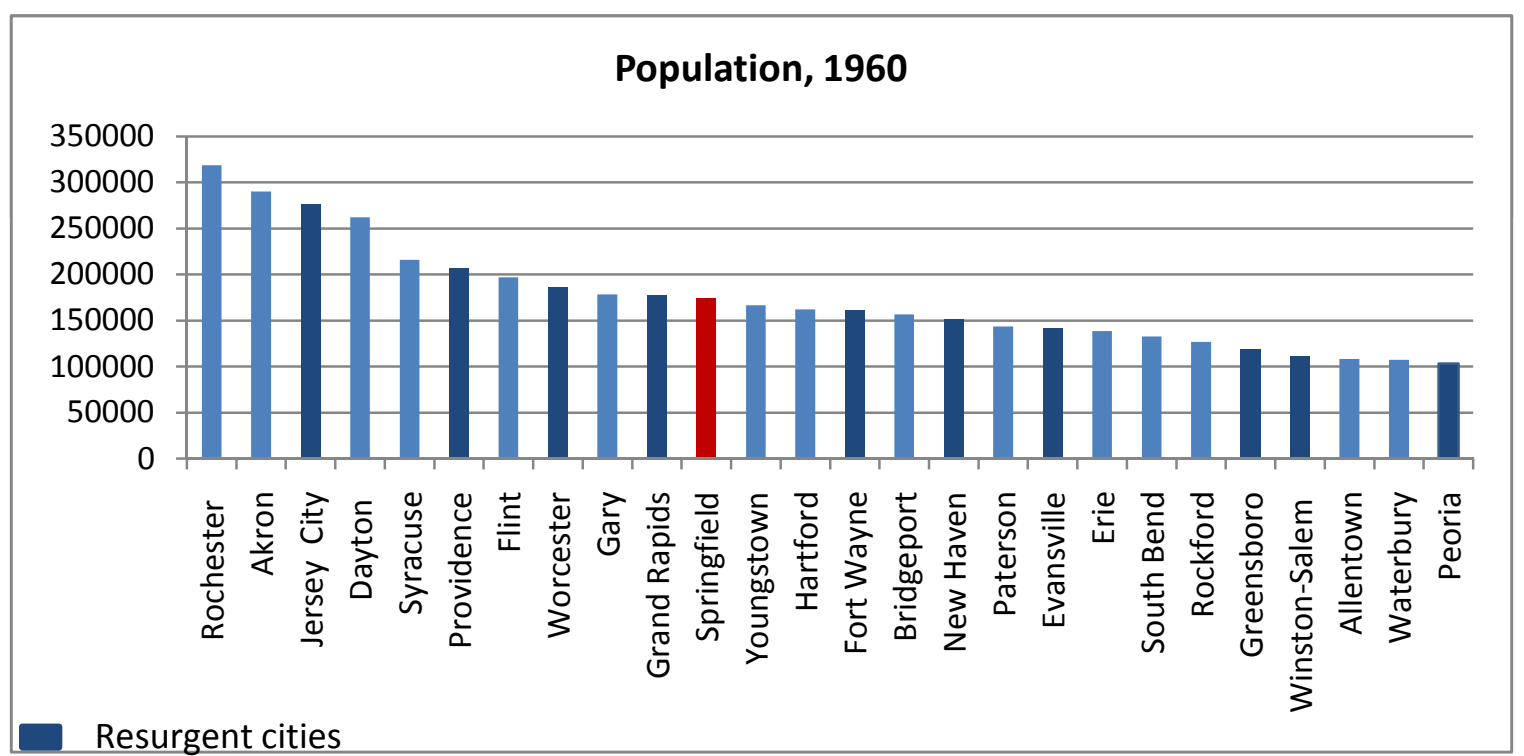

Source: U.S. Bureau of the Census. County and City Data Book (1960). 
Figure 4
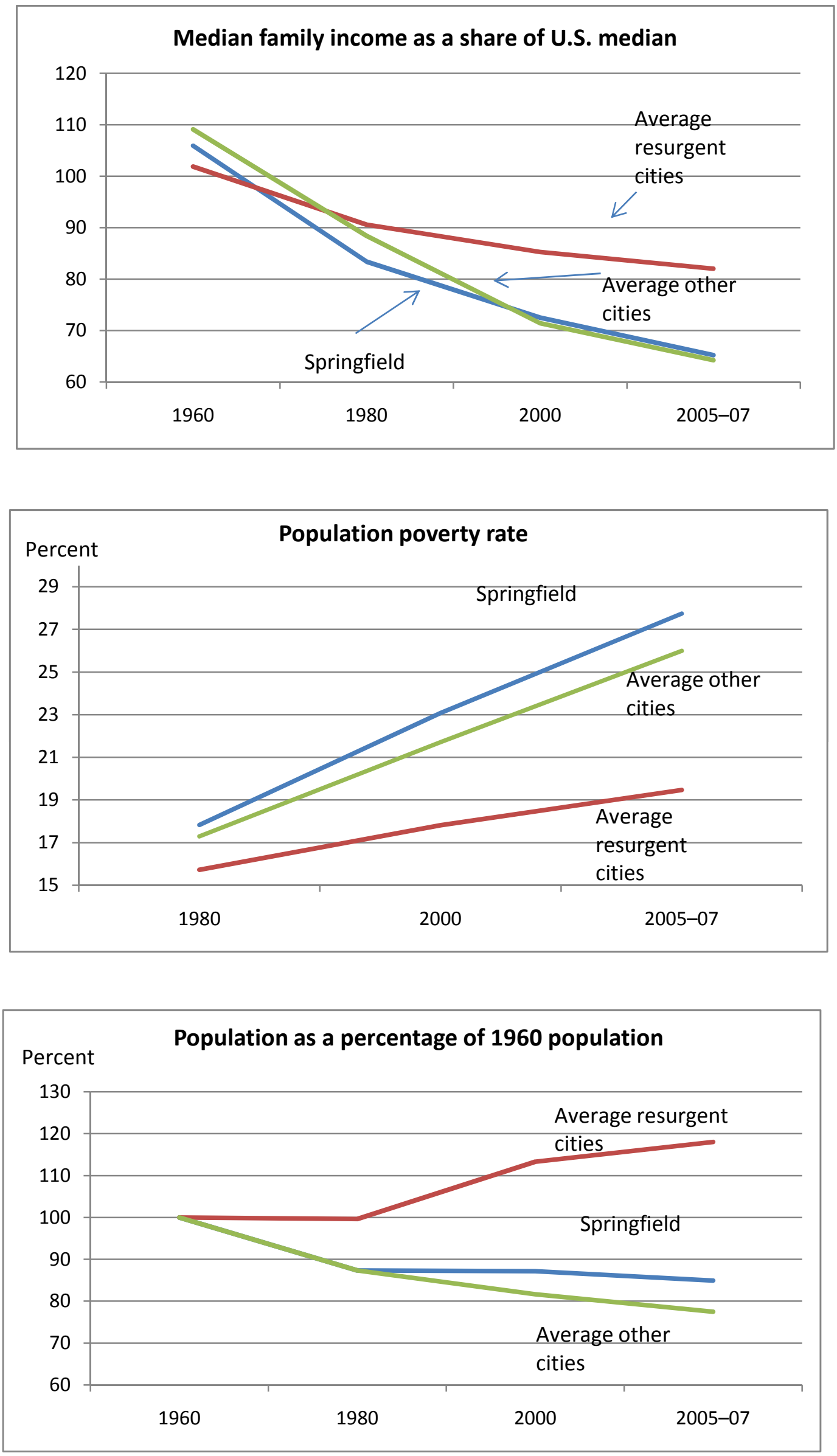

Source: U.S. Bureau of the Census. County and City Data Book (1960), Decennial Census (1980 and 2000), American Community Survey (2005-2007). 
Figure 5

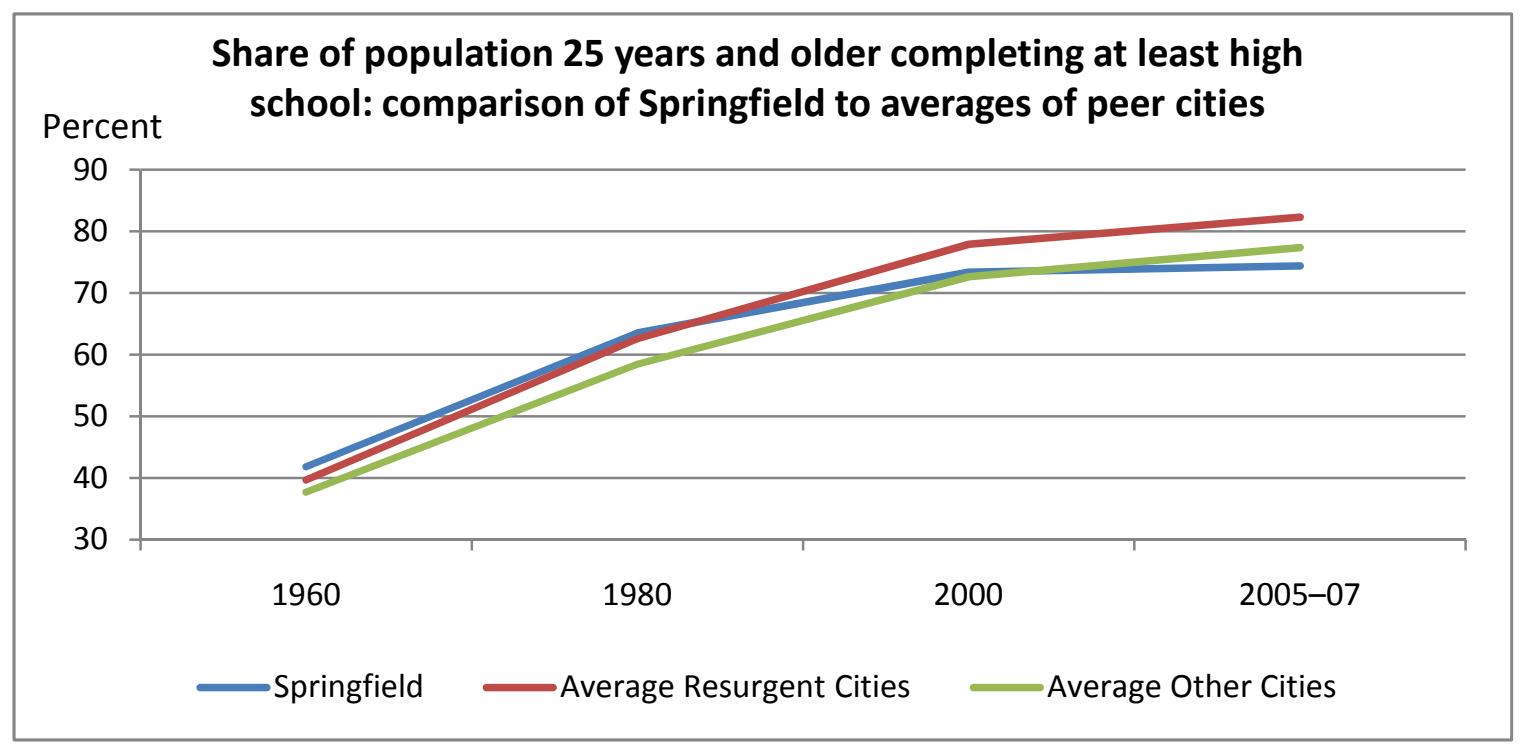

Source: U.S. Bureau of the Census. County and City Data Book (1960), Decennial Census (1980 and 2000), American Community Survey (2005-2007).

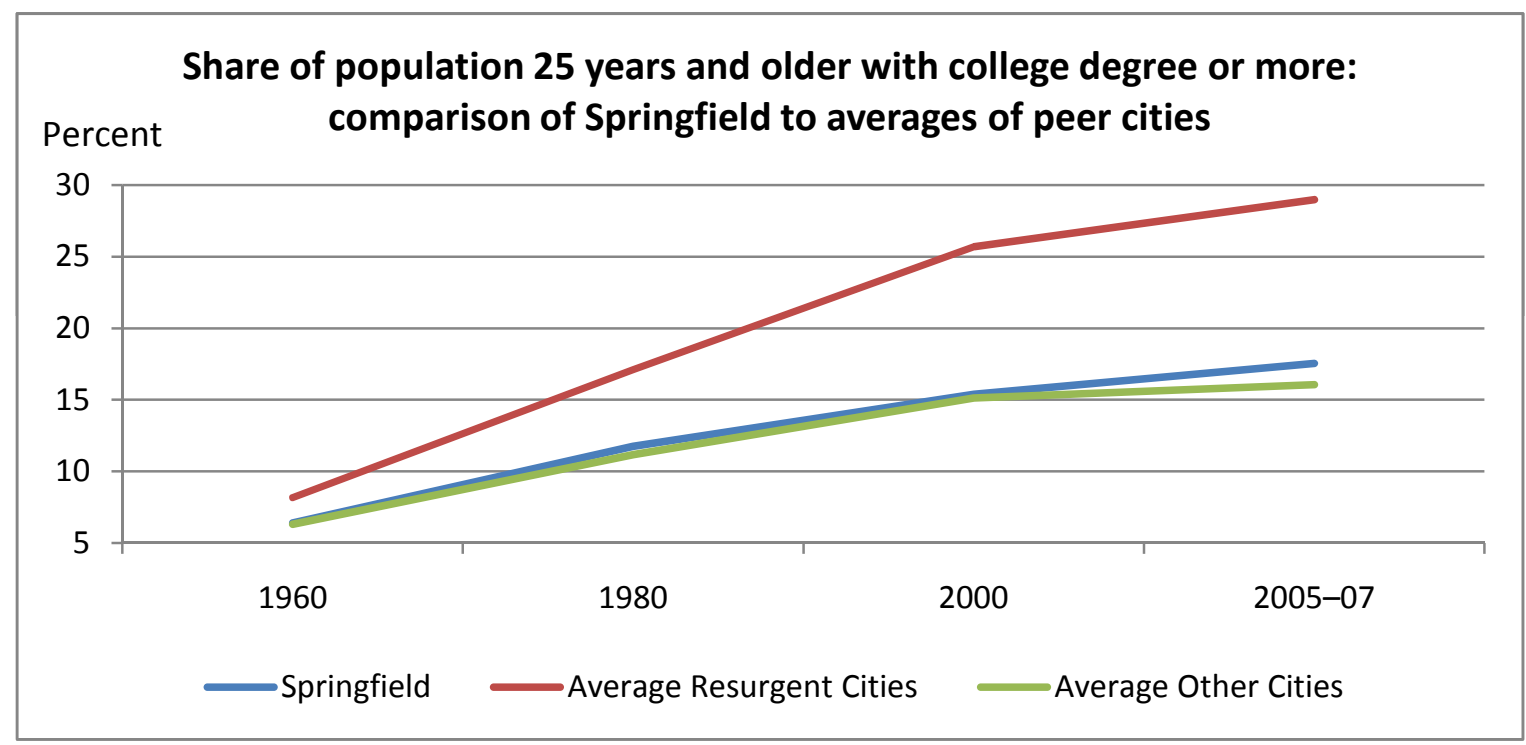

Source: U.S. Bureau of the Census. County and City Data Book (1960), Decennial Census (1980 and 2000), American Community Survey (2005-2007). 
Figure 6

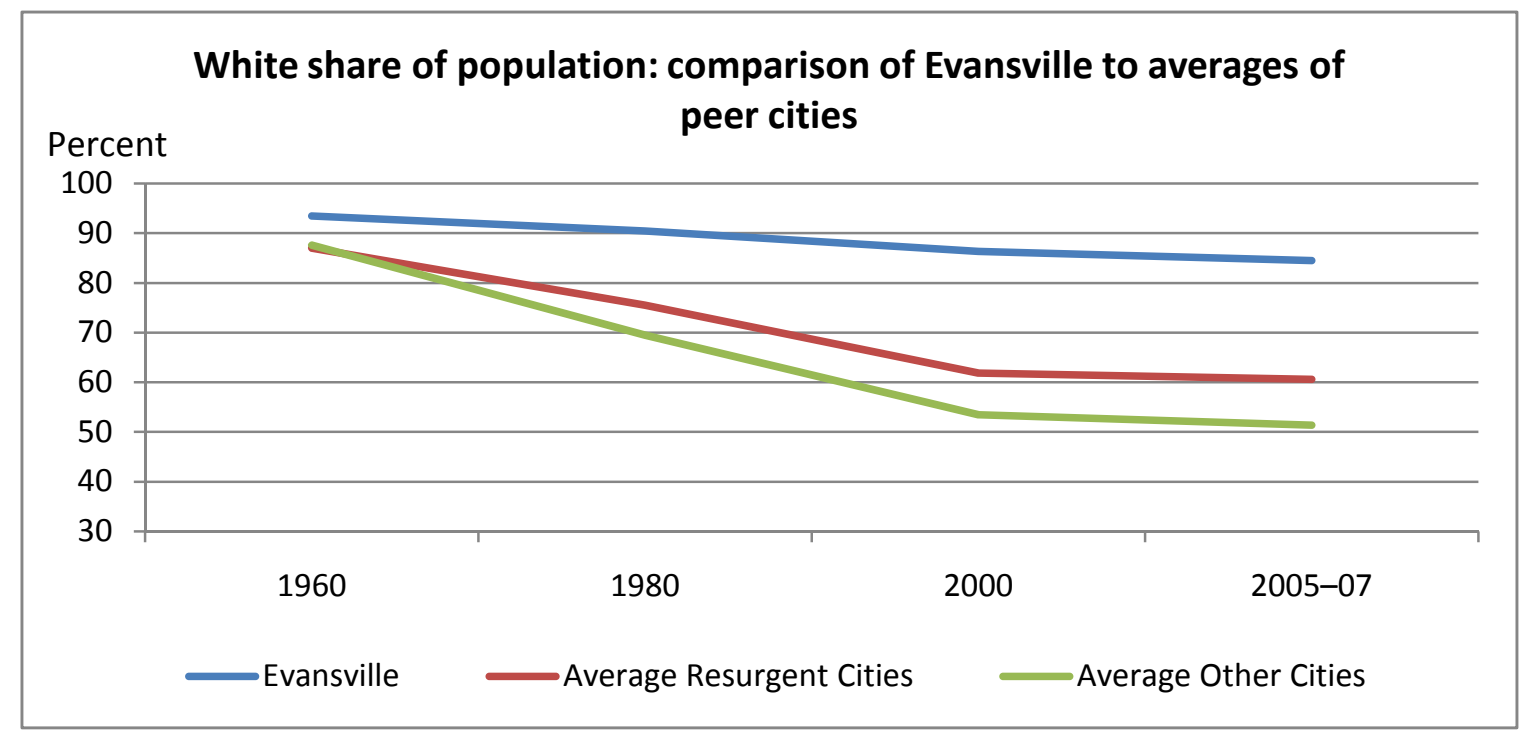

Source: U.S. Bureau of the Census. County and City Data Book (1960), Decennial Census (1980 and 2000), American Community Survey (2005-2007). 
Figure 7

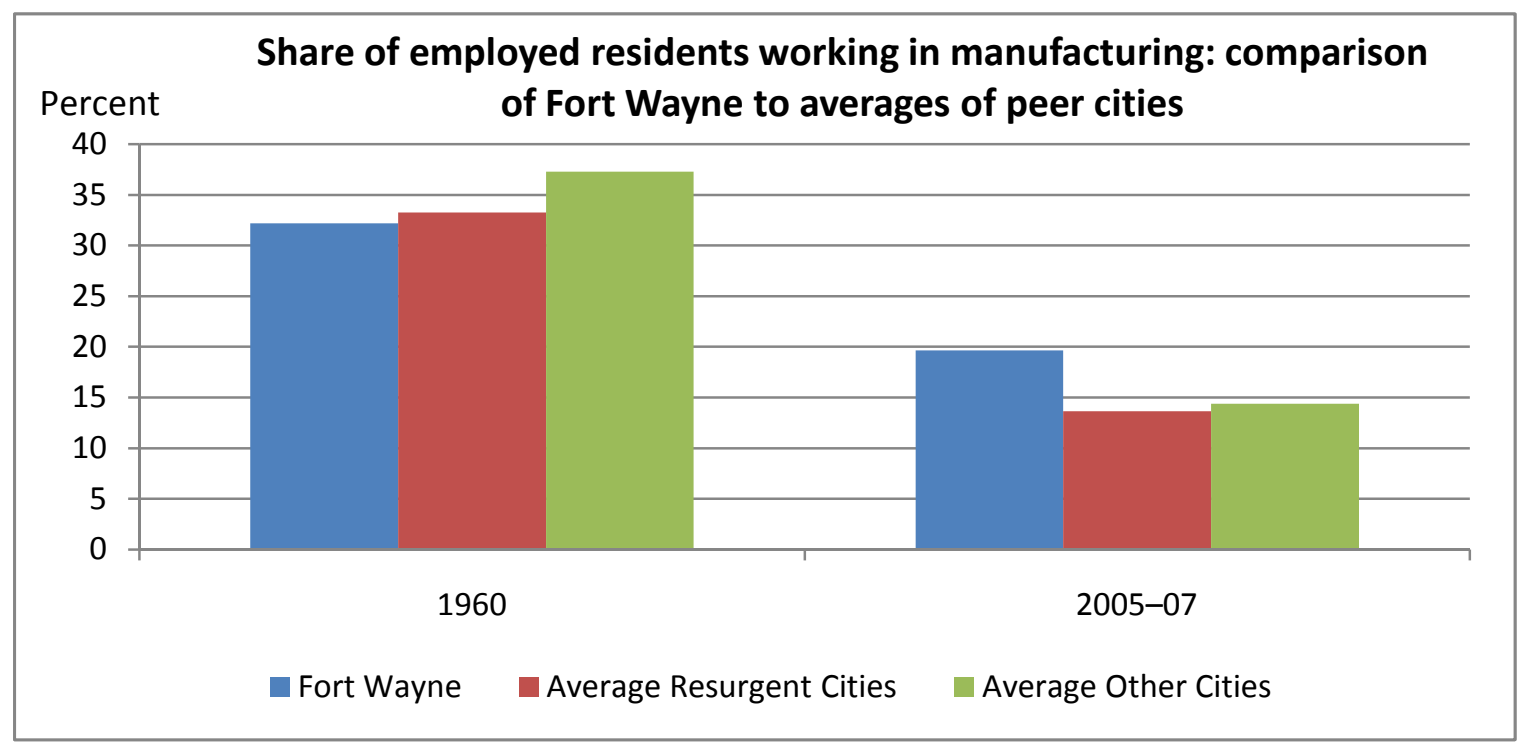

Source: U.S. Bureau of the Census. County and City Data Book (1960), American Community Survey (2005-2007).

Figure 8

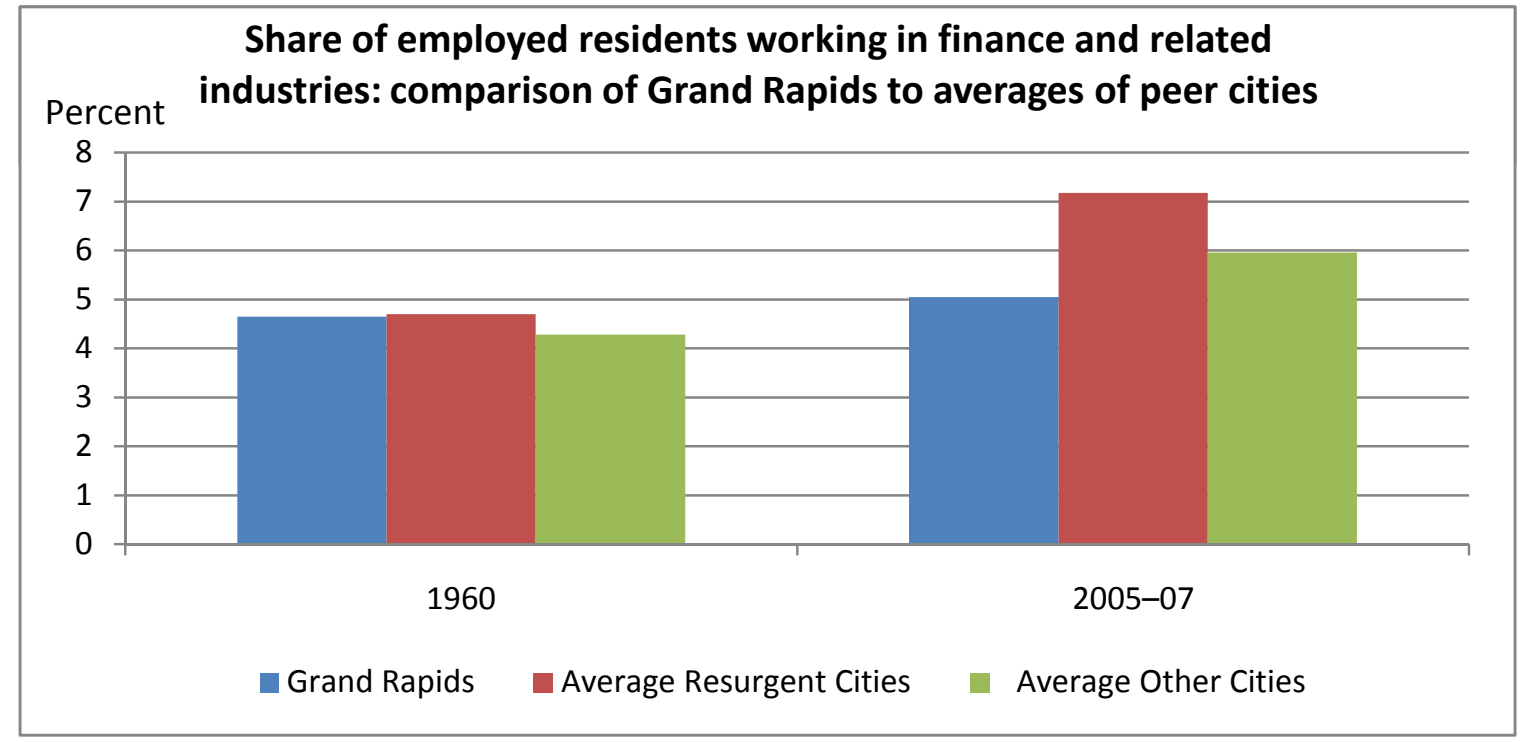

Source: U.S. Bureau of the Census. County and City Data Book (1960), American Community Survey (2005-2007). 
Figure 9

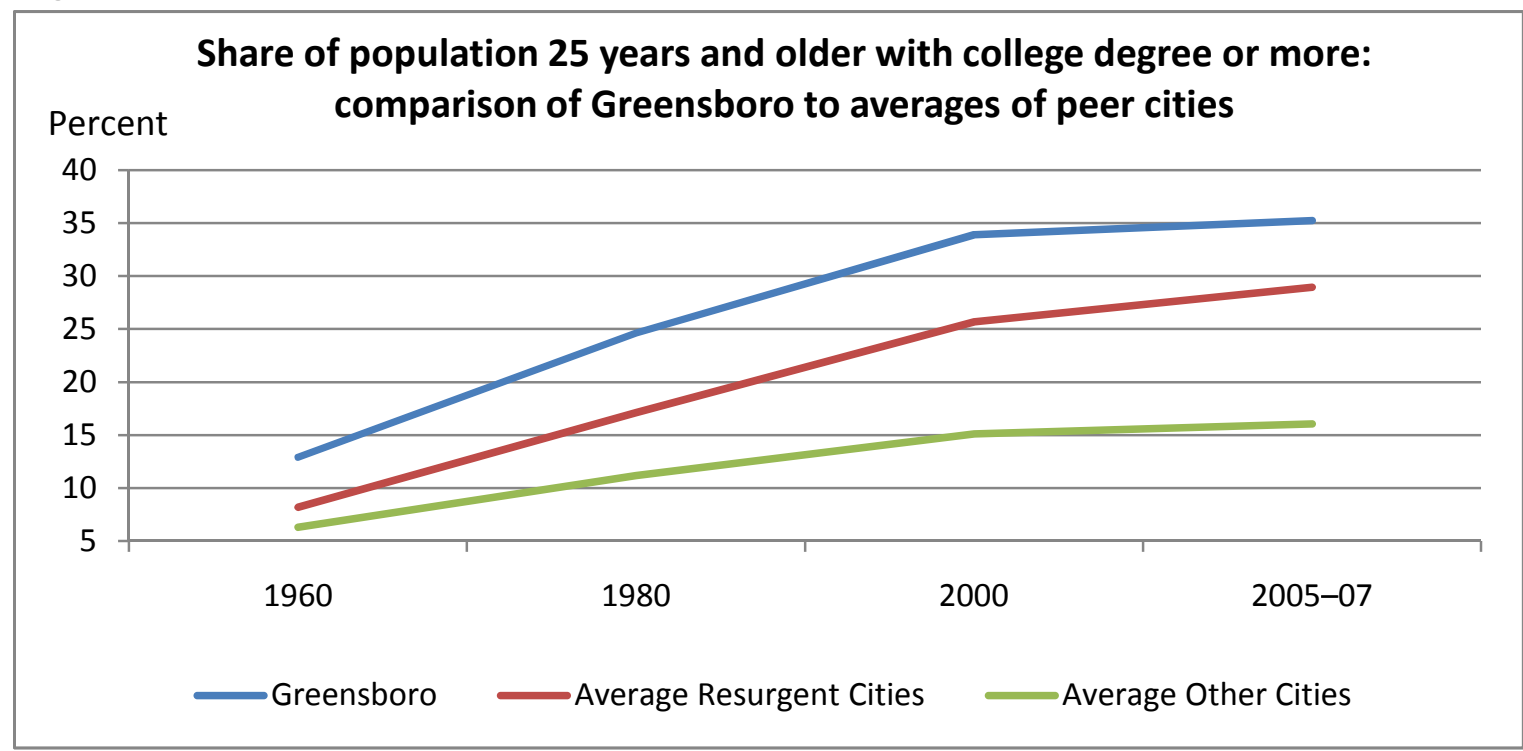

Source: U.S. Bureau of the Census. County and City Data Book (1960), Decennial Census (1980 and 2000), American Community Survey (2005-07).

Figure 10

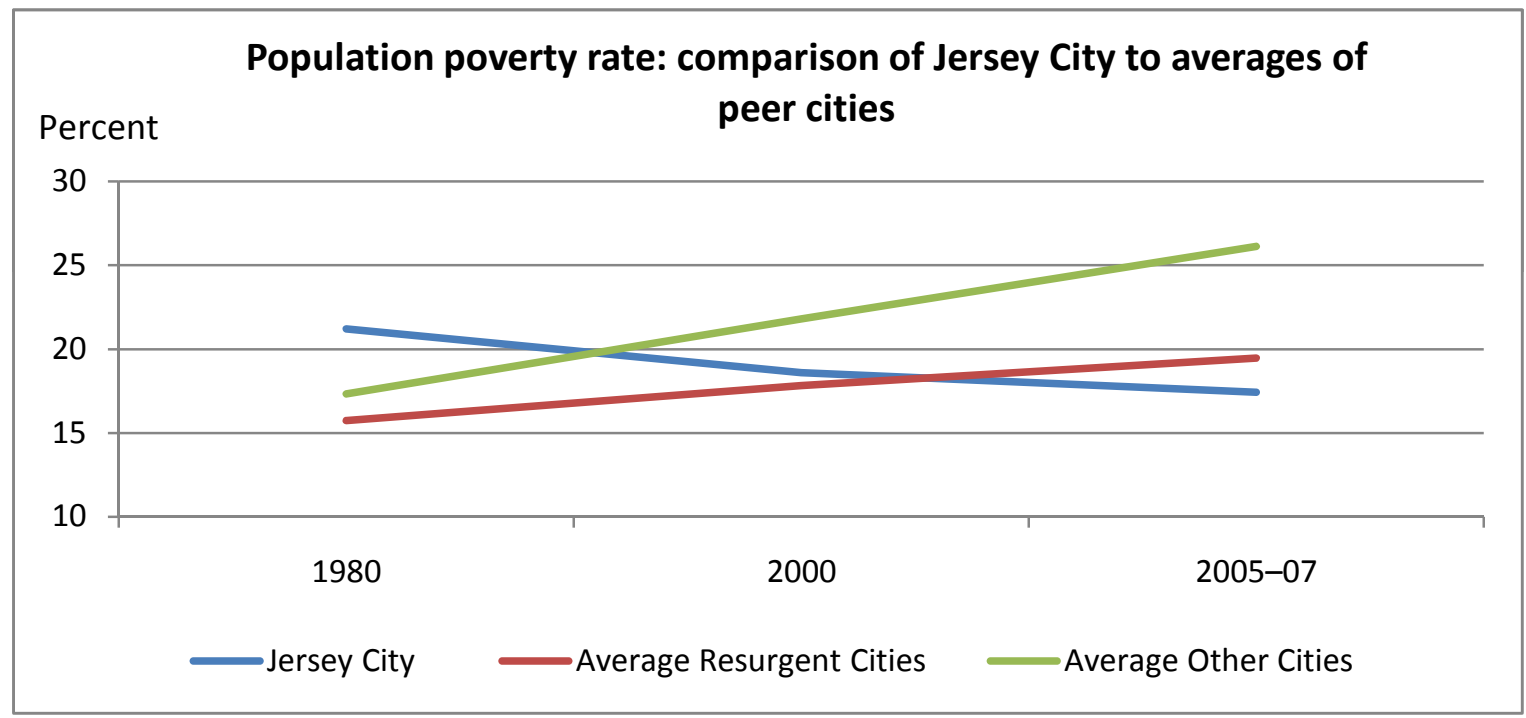

Source: U.S. Bureau of the Census. County and City Data Book (1960), Decennial Census (1980 and 2000), American Community Survey (2005-2007). 
Figure 11

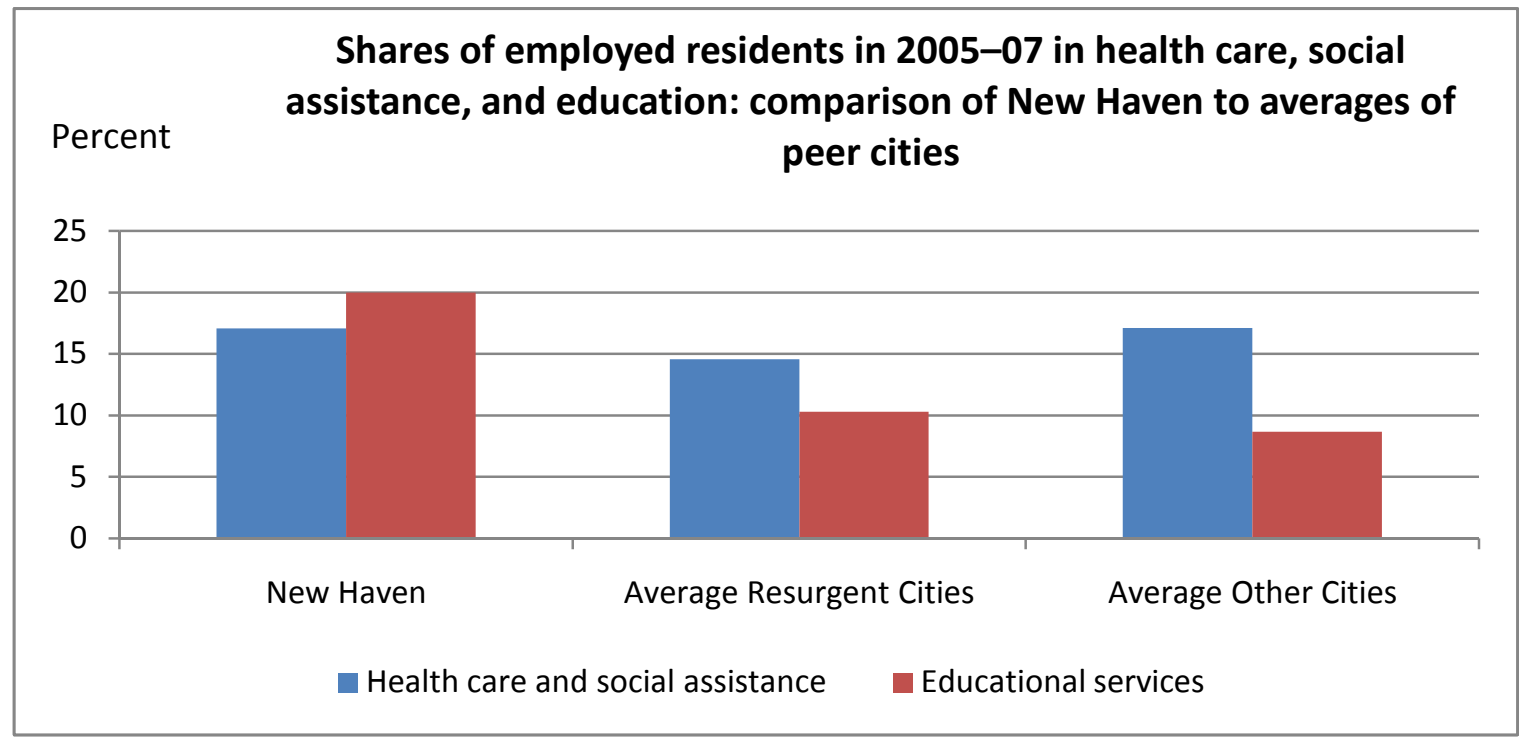

Source: U.S. Bureau of the Census. American Community Survey (2005-2007).

Figure 12

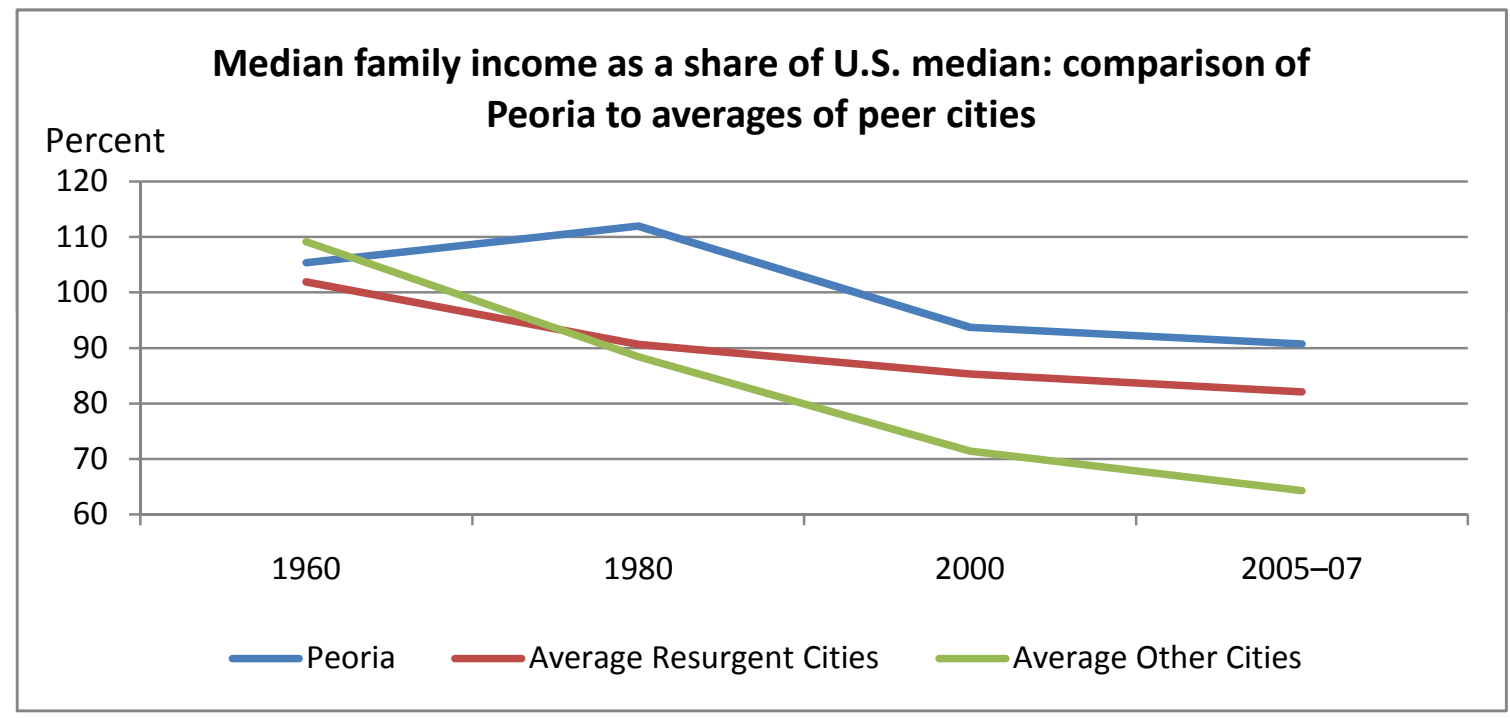

Source: U.S. Bureau of the Census. County and City Data Book (1960), Decennial Census (1980 and 2000), American Community Survey (2005-2007). 
Figure 13

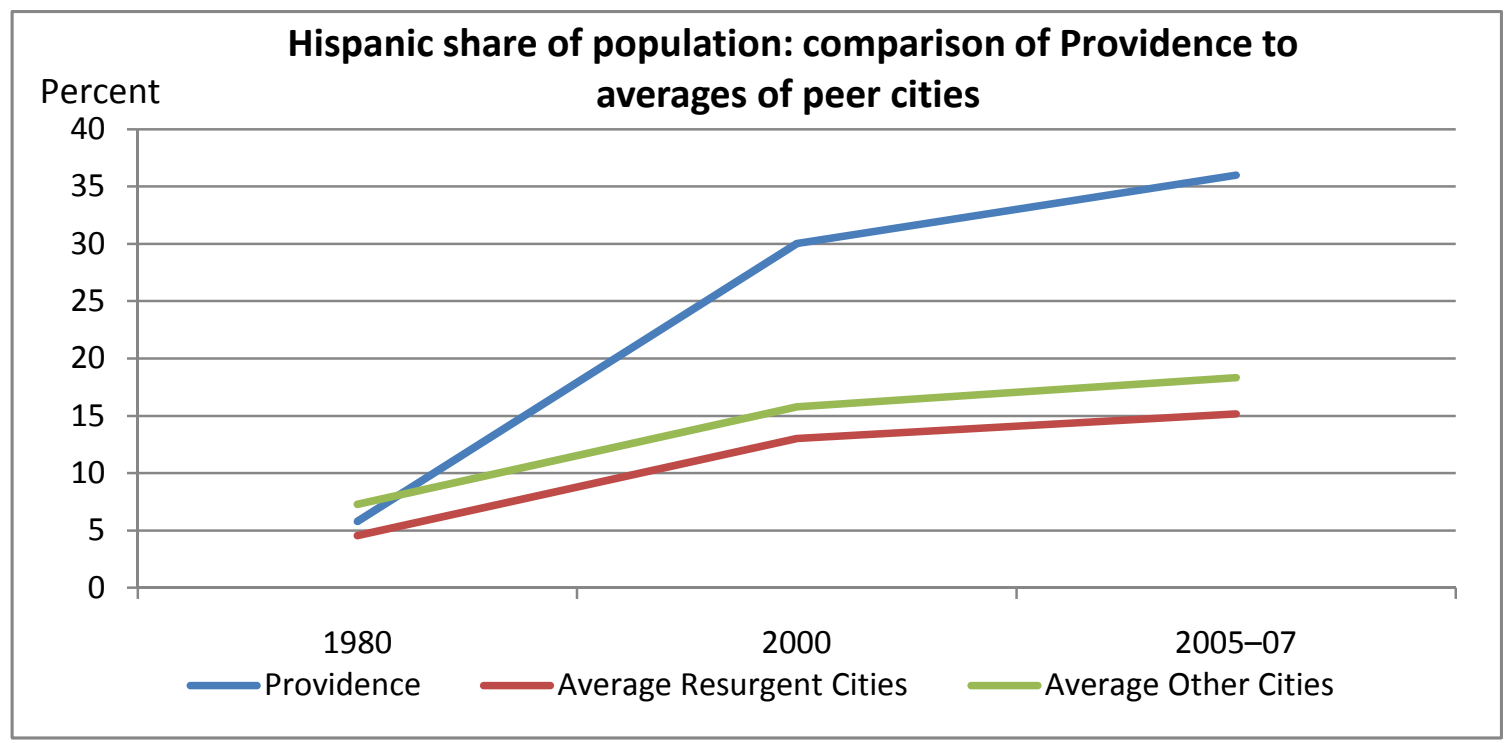

Source: U.S. Bureau of the Census. County and City Data Book (1960), Decennial Census (1980 and 2000), American Community Survey (2005-2007).

Figure 14

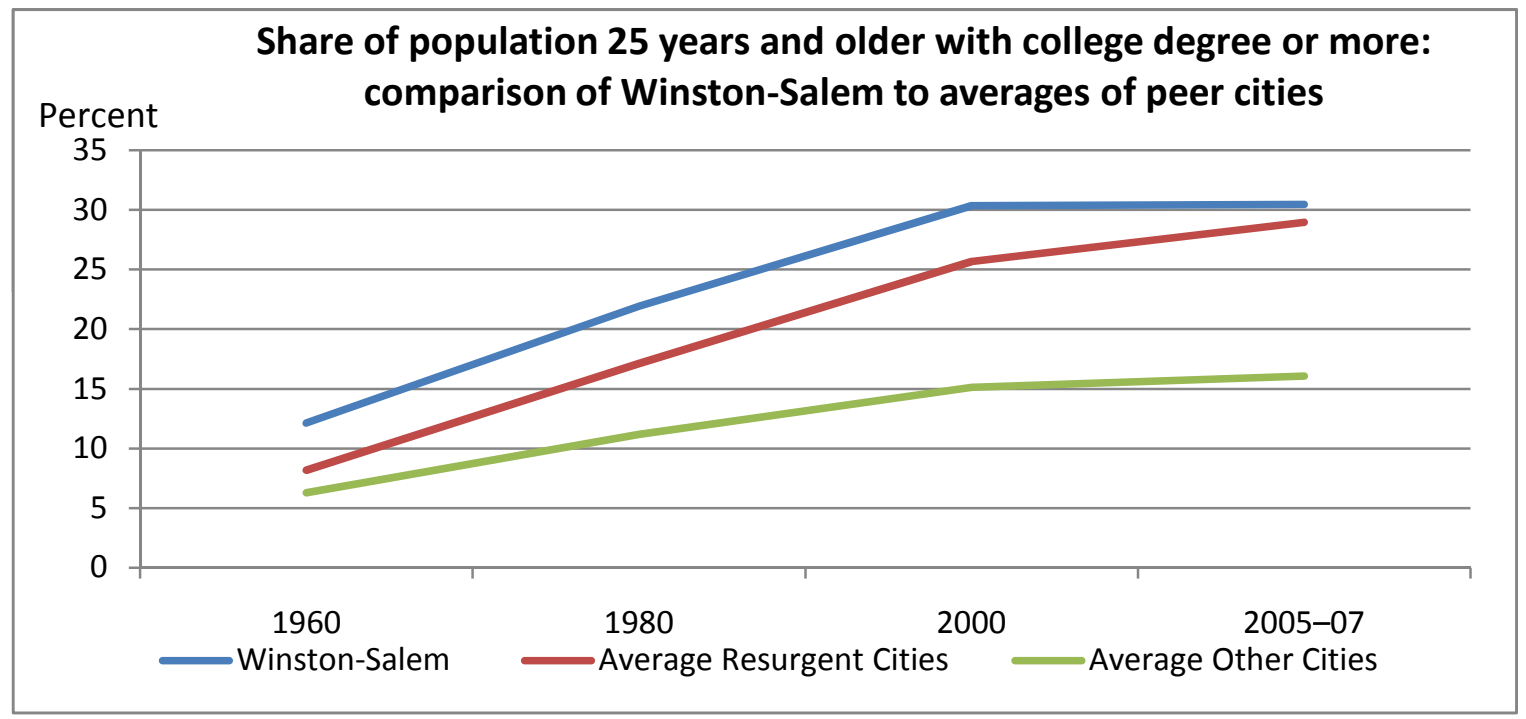

Source: U.S. Bureau of the Census. County and City Data Book (1960), Decennial Census (1980 and 2000), American Community Survey (2005-2007). 
Figure 15

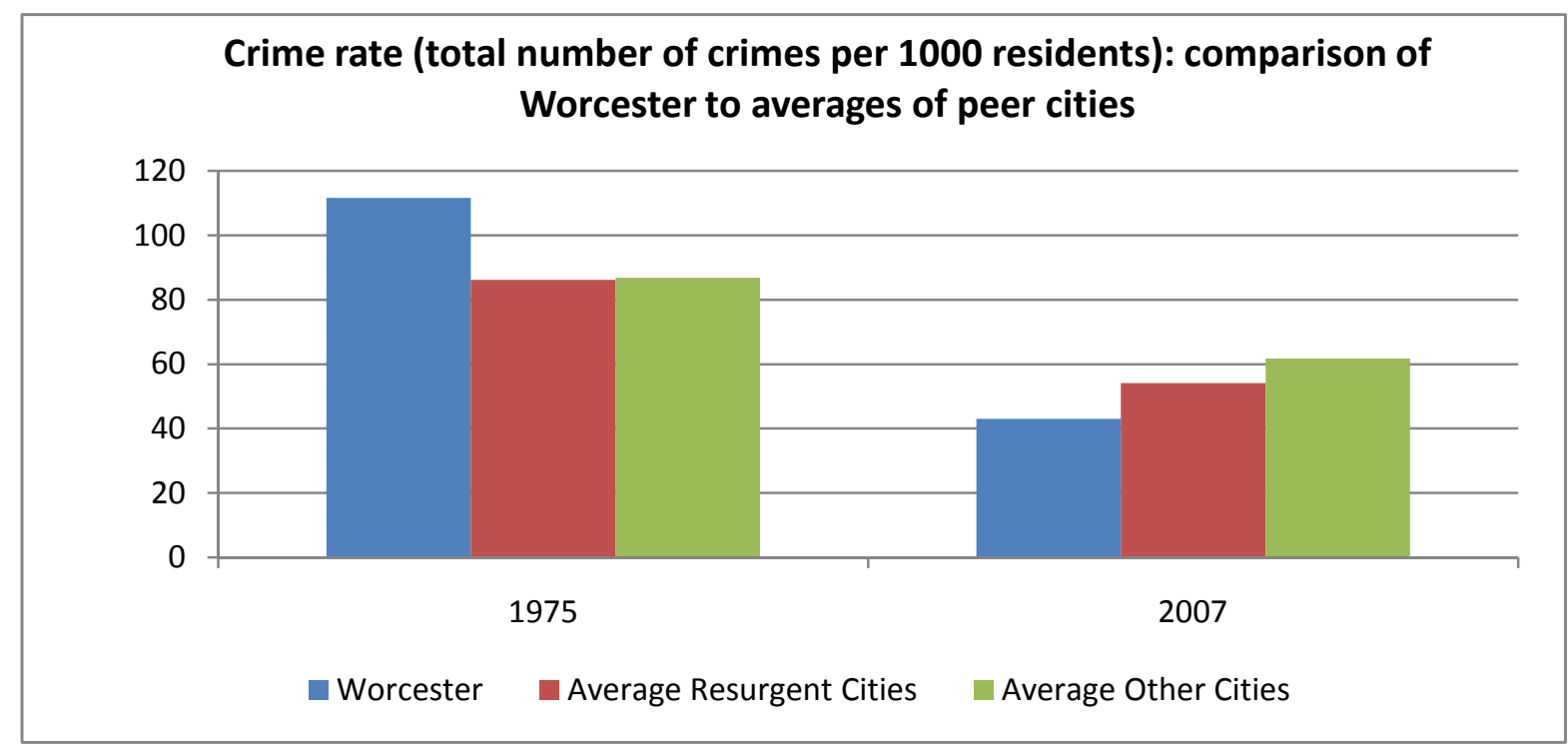

Source: U.S. Bureau of the Census. County cand City Data Book (1975); U.S. Department of Justice, Federal Bureau of Investigation. Crime in the United States, 2007. 
Table 1 Key Economic Indicators for Springfield and Peer-Group Cities, 1960 to 2005-07

\begin{tabular}{|c|c|c|c|c|c|c|c|c|c|c|c|c|}
\hline & & \multicolumn{4}{|c|}{ Median family income } & \multicolumn{3}{|c|}{ Population Poverty Rate } & \multicolumn{3}{|c|}{ Population } & \multirow{2}{*}{$\begin{array}{c}\text { More than } \\
10 \% \\
\text { expansion in } \\
\text { land area, } \\
1960 \text { to } 2000\end{array}$} \\
\hline & & $\begin{array}{l}1960 \\
\text { Percent }\end{array}$ & $\begin{array}{l}\text { 005-07 } \\
\text { median }\end{array}$ & $\begin{array}{r}1960 \\
\text { Rank ( }\end{array}$ & $\begin{array}{l}2005-07 \\
\text { highest) }\end{array}$ & 1980 & $\begin{array}{l}\text { 2005-07 } \\
\text { ent }\end{array}$ & $\begin{array}{c}\text { Percentage } \\
\text { point change } \\
1980 \text { to } \\
2005-07\end{array}$ & 1960 & 2005-07 & $\begin{array}{c}2005-07 \text { as a } \\
\text { percentage of } \\
1960\end{array}$ & \\
\hline \multirow{10}{*}{ 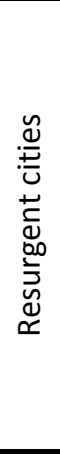 } & Evansville & 93.6 & 76.9 & 25 & 8 & 12.2 & 17.8 & 5.6 & 141,543 & 113,627 & 80.3 & yes \\
\hline & Fort Wayne & 114.7 & 89.4 & 4 & 3 & 11.0 & 13.9 & 2.9 & 161,776 & 249,830 & 154.4 & yes \\
\hline & Grand Rapids & 107.2 & 75.2 & 10 & 11 & 13.5 & 21.9 & 8.4 & 177,313 & 193,671 & 109.2 & yes \\
\hline & Greensboro & 103.3 & 87.8 & 19 & 4 & 12.8 & 18.7 & 5.9 & 119,574 & 237,423 & 198.6 & yes \\
\hline & Jersey City & 105.1 & 80.1 & 17 & 6 & 21.2 & 17.4 & -3.8 & 276,101 & 234,914 & 85.1 & yes \\
\hline & New Haven & 103.6 & 71.9 & 18 & 13 & 23.2 & 24.0 & 0.8 & 152,048 & 123,507 & 81.2 & no \\
\hline & Peoria & 105.3 & 90.7 & 16 & 2 & 12.3 & 16.9 & 4.7 & 103,162 & 111,351 & 107.9 & yes \\
\hline & Providence & 89.6 & 70.2 & 26 & 14 & 20.4 & 27.2 & 6.9 & 207,498 & 170,220 & 82.0 & no \\
\hline & Winston-Salem & 93.9 & 85.6 & 24 & 5 & 16.4 & 18.6 & 2.2 & 111,135 & 213,889 & 192.5 & yes \\
\hline & Worcester & 102.5 & 92.4 & 20 & 1 & 14.4 & 18.3 & 3.9 & 186,587 & 165,965 & 88.9 & no \\
\hline \multirow{16}{*}{ 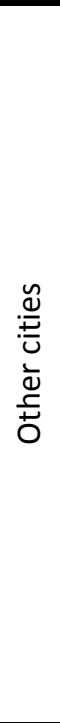 } & Springfield & 105.9 & 65.2 & 13 & 18 & 17.8 & 27.7 & 9.9 & 174,463 & 148,136 & 84.9 & no \\
\hline & Akron & 114.2 & 69.0 & 5 & 16 & 15.0 & 21.4 & 6.4 & 290,351 & 200,172 & 68.9 & yes \\
\hline & Allentown & 106.9 & 67.1 & 11 & 17 & 11.7 & 22.3 & 10.6 & 108,347 & 108,900 & 100.5 & no \\
\hline & Bridgeport & 105.7 & 76.8 & 15 & 9 & 20.4 & 19.2 & -1.2 & 156,748 & 130,748 & 83.4 & no \\
\hline & Dayton & 110.7 & 58.9 & 8 & 21 & 20.8 & 29.6 & 8.8 & 262,332 & 146,762 & 55.9 & yes \\
\hline & Erie & 101.3 & 69.5 & 22 & 15 & 13.4 & 24.3 & 10.8 & 138,440 & 100,393 & 72.5 & yes \\
\hline & Flint & 112.0 & 55.5 & 7 & 23 & 16.9 & 33.2 & 16.3 & 196,940 & 108,304 & 55.0 & yes \\
\hline & Gary & 106.1 & 56.7 & 12 & 22 & 20.4 & 33.2 & 12.8 & 178,320 & 86,723 & 48.6 & yes \\
\hline & Hartford & 105.8 & 51.0 & 14 & 26 & 25.2 & 31.5 & 6.3 & 162,178 & 118,655 & 73.2 & no \\
\hline & Paterson & 97.9 & 63.3 & 23 & 19 & 25.2 & 24.5 & -0.7 & 143,663 & 142,443 & 99.2 & no \\
\hline & Rochester & 112.4 & 54.8 & 6 & 24 & 17.5 & 30.0 & 12.5 & 318,611 & 199,697 & 62.7 & no \\
\hline & Rockford & 121.3 & 78.7 & 1 & 7 & 10.3 & 20.2 & 9.9 & 126,706 & 147,794 & 116.6 & yes \\
\hline & South Bend & 118.1 & 73.5 & 2 & 12 & 12.1 & 21.6 & 9.5 & 132,445 & 98,516 & 74.4 & yes \\
\hline & Syracuse & 110.4 & 59.0 & 9 & 20 & 18.4 & 30.7 & 12.3 & 216,038 & 139,896 & 64.8 & no \\
\hline & Waterbury & 115.5 & 76.0 & 3 & 10 & 14.1 & 18.8 & 4.7 & 107,130 & 108,554 & 101.3 & no \\
\hline & Youngstown & 101.6 & 52.9 & 21 & 25 & 18.2 & 29.6 & 11.4 & 166,689 & 68,592 & 41.1 & no \\
\hline \multirow{3}{*}{ 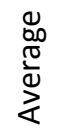 } & All cities & 106.3 & 71.1 & & & 16.7 & 23.6 & 6.8 & 173,698 & 148,795 & 91.7 & \\
\hline & Resurgent cities & 101.9 & 82.0 & & & 15.7 & 19.5 & 3.7 & 163,674 & 181,440 & 118.0 & \\
\hline & Other cities & 109.1 & 64.3 & & & 17.3 & 26.1 & 8.8 & 179,963 & 128,393 & 75.2 & \\
\hline
\end{tabular}

Source: U.S. Bureau of the Census. County and City Data Book (1960), American Community Survey (2005-2007). 
Table 2 Employment by SIC Industry, 1960 (percentages of total city resident employment)

\begin{tabular}{|c|c|c|c|c|c|c|}
\hline & & Manufacturing & $\begin{array}{c}\text { Retail and } \\
\text { wholesale trade }\end{array}$ & $\begin{array}{c}\text { Educational } \\
\text { services }\end{array}$ & $\begin{array}{l}\text { Finance, } \\
\text { insurance, } \\
\text { and real } \\
\text { estate }\end{array}$ & All Other* \\
\hline \multirow{11}{*}{ 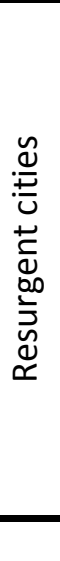 } & Evansville & 30.6 & 22.1 & 4.6 & 3.9 & 38.8 \\
\hline & Fort Wayne & 32.2 & 21.1 & 4.2 & 5.5 & 37.0 \\
\hline & Grand Rapids & 34.8 & 21.3 & 4.7 & 4.6 & 34.6 \\
\hline & Greensboro & 29.5 & 20.2 & 7.0 & 5.9 & 37.3 \\
\hline & Jersey City & 33.2 & 15.4 & 3.3 & 6.9 & 41.2 \\
\hline & New Haven & 31.5 & 16.3 & 9.3 & 3.7 & 39.2 \\
\hline & Peoria & 32.0 & 21.3 & 4.1 & 4.6 & 38.0 \\
\hline & Providence & 34.5 & 16.8 & 6.1 & 3.7 & 39.0 \\
\hline & Winston-Salem & 36.2 & 15.5 & 6.6 & 3.5 & 38.3 \\
\hline & Worcester & 37.9 & 18.6 & 5.7 & 4.7 & 33.0 \\
\hline & Springfield & 33.9 & 19.8 & 4.2 & 6.2 & 35.9 \\
\hline \multirow{3}{*}{$\begin{array}{l}0 \\
00 \\
\frac{0}{0} \\
\frac{0}{4} \\
\frac{1}{4}\end{array}$} & All cities & 38.4 & 17.9 & 4.8 & 4.3 & 34.7 \\
\hline & Resurgent cities** & 33.2 & 18.9 & 5.6 & 4.7 & 37.6 \\
\hline & Other cities** & 41.6 & 17.3 & 4.2 & 4.0 & 32.8 \\
\hline
\end{tabular}

* Agriculture and mining; Construction; Transportation and utilities; Other services; and Public administration.

** None of the averages for the resurgent cities is statistically significantly different from the averages for the other cities.

Source: U.S. Bureau of the Census. County and City Data Book (1960). 
Table 3 Employment by NAICS Industry, 2005-07 (percentages of total city resident employment)

\begin{tabular}{|c|c|c|c|c|c|c|c|c|c|c|}
\hline & & $\begin{array}{c}\text { Health } \\
\text { care and } \\
\text { social } \\
\text { assistance }\end{array}$ & $\begin{array}{c}\text { Manufac- } \\
\text { turing }\end{array}$ & $\begin{array}{l}\text { Retail } \\
\text { trade }\end{array}$ & $\begin{array}{c}\text { Educational } \\
\text { services }\end{array}$ & $\begin{array}{c}\text { Leisure } \\
\text { and } \\
\text { hospitality }\end{array}$ & $\begin{array}{c}\text { Professional } \\
\text { and business } \\
\text { services }\end{array}$ & $\begin{array}{l}\text { Financial } \\
\text { activities }\end{array}$ & $\begin{array}{c}\text { Other } \\
\text { services }\end{array}$ & All Other* \\
\hline \multirow{11}{*}{ 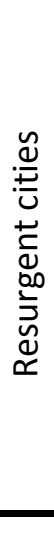 } & Evansville & 11.9 & 16.3 & 14.3 & 5.7 & 11.4 & 8.9 & 6.0 & 6.1 & 19.4 \\
\hline & Fort Wayne & 14.5 & 19.6 & 11.1 & 7.2 & 9.7 & 8.1 & 6.2 & 4.3 & 19.2 \\
\hline & Grand Rapids & 14.4 & 18.1 & 11.6 & 8.7 & 9.9 & 9.6 & 5.0 & 5.2 & 17.5 \\
\hline & Greensboro & 12.1 & 12.5 & 12.4 & 11.2 & 10.1 & 9.0 & 8.2 & 3.3 & 21.2 \\
\hline & Jersey City & 12.7 & 6.4 & 8.7 & 7.2 & 7.6 & 13.5 & 14.3 & 4.7 & 25.0 \\
\hline & New Haven & 17.1 & 9.9 & 10.2 & 20.0 & 8.3 & 8.6 & 5.1 & 5.7 & 15.2 \\
\hline & Peoria & 16.3 & 15.8 & 10.8 & 8.9 & 10.5 & 9.7 & 6.3 & 5.4 & 16.3 \\
\hline & Providence & 14.8 & 15.0 & 10.8 & 12.6 & 12.5 & 8.5 & 6.5 & 4.3 & 14.9 \\
\hline & Winston-Salem & 15.7 & 11.8 & 10.9 & 9.7 & 9.9 & 9.5 & 7.9 & 4.8 & 19.7 \\
\hline & Worcester & 16.0 & 11.2 & 12.8 & 11.6 & 9.3 & 9.1 & 6.3 & 5.1 & 18.7 \\
\hline & Springfield & 19.1 & 12.5 & 10.2 & 8.8 & 9.0 & 7.4 & 6.9 & 5.0 & 21.0 \\
\hline \multirow{3}{*}{ 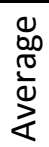 } & All cities & 16.1 & 14.4 & 11.9 & 9.3 & 9.9 & 8.6 & 6.0 & 5.0 & 18.9 \\
\hline & Resurgent cities & $14.5^{* *}$ & 13.7 & 11.4 & 10.3 & 9.9 & $9.5 * *$ & $7.2 * *$ & 4.9 & 18.7 \\
\hline & Other cities & $17.1 * *$ & 14.8 & 12.2 & 8.7 & 9.9 & $8.1 * *$ & $5.2 * *$ & 5.0 & 19.0 \\
\hline
\end{tabular}

*Natural resources; Construction; Wholesale trade; Transportation, warehousing, and utilities; Information; and Government.

** Average for resurgent cities is statistically significantly different from the average for the other cities in Healthcare and social assistance; Professional and business services; and Financial activities.

Source: U.S. Bureau of the Census. American Community Survey (2005-2007). 
Table 4 Race (percent of population***)

\begin{tabular}{|c|c|c|c|c|c|c|c|}
\hline & \multicolumn{2}{|c|}{ White } & \multicolumn{2}{|c|}{ Black } & \multicolumn{2}{|c|}{ All Other* } \\
\hline & & 1960 & 2005-07 & 1960 & 2005-07 & 1960 & 2005-07 \\
\hline \multirow{11}{*}{ 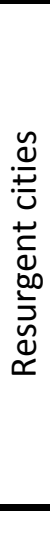 } & Evansville & 93.4 & 86.1 & 6.6 & 11.7 & 0.0 & 2.2 \\
\hline & Fort Wayne & 92.6 & 78.4 & 7.2 & 15.5 & 0.2 & 6.1 \\
\hline & Grand Rapids & 91.7 & 68.5 & 8.0 & 21.1 & 0.3 & 10.4 \\
\hline & Greensboro & 74.0 & 52.6 & 25.8 & 39.7 & 0.2 & 7.6 \\
\hline & Jersey City & 86.5 & 35.5 & 13.3 & 28.7 & 0.2 & 35.9 \\
\hline & New Haven & 85.1 & 45.7 & 14.5 & 36.8 & 0.4 & 17.6 \\
\hline & Peoria & 90.5 & 67.8 & 9.3 & 26.7 & 0.2 & 5.4 \\
\hline & Providence & 94.2 & 50.3 & 5.4 & 15.6 & 0.4 & 34.1 \\
\hline & Winston-Salem & 62.9 & 55.0 & 37.1 & 34.7 & 0.0 & 10.3 \\
\hline & Worcester & 98.8 & 79.7 & 1.1 & 9.0 & 0.1 & 11.3 \\
\hline & Springfield & 92.3 & 52.4 & 7.5 & 22.4 & 0.2 & 25.1 \\
\hline \multirow{3}{*}{$\begin{array}{l}0 \\
0 \\
0 \\
\frac{\pi}{2} \\
\frac{1}{2}\end{array}$} & All cities & 87.4 & 56.4 & 12.5 & 30.6 & 0.2 & 13.0 \\
\hline & Resurgent cities** & 87.0 & 62.0 & 12.8 & 24.0 & 0.2 & 14.1 \\
\hline & Other cities** & 87.6 & 52.9 & 12.3 & 34.7 & 0.2 & 12.4 \\
\hline
\end{tabular}

*Asian; American Indian and Alaska Native; Native Hawaiian and Other Pacific Islander; or some other race.

** None of the averages for the resurgent cities is statistically significantly different from the averages for the other cities.

Note: In 2005-07, entries show the number of white-alone and black-alone populations as a percent of total single-race population, with all other and mixed races as the residual.

Source: U.S. Bureau of the Census. American Community Survey (2005-2007).

Table 5 Hispanic population (percent of total residents)

\begin{tabular}{|c|c|c|c|}
\hline & & 1980 & 2005-07 \\
\hline \multirow{11}{*}{ 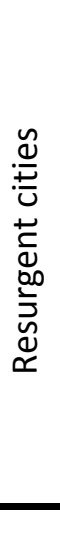 } & Evansville & 0.5 & 1.5 \\
\hline & Fort Wayne & 2.2 & 6.8 \\
\hline & Grand Rapids & 3.2 & 16.4 \\
\hline & Greensboro & 0.8 & 6.5 \\
\hline & Jersey City & 18.6 & 27.7 \\
\hline & New Haven & 8.0 & 24.0 \\
\hline & Peoria & 1.4 & 2.9 \\
\hline & Providence & 5.8 & 36.0 \\
\hline & Winston-Salem & 0.8 & 12.2 \\
\hline & Worcester & 4.3 & 17.7 \\
\hline & Springfield & 9.1 & 33.6 \\
\hline \multirow{3}{*}{$\begin{array}{l}0 \\
00 \\
\frac{0}{0} \\
\frac{0}{2}\end{array}$} & All cities & 6.2 & 17.1 \\
\hline & Resurgent cities' & 4.5 & 15.2 \\
\hline & Other cities** & 7.3 & 18.3 \\
\hline
\end{tabular}

** Neither for the resurgent cities is statistically significantly different from the averages for the other cities.

Source: U.S. Bureau of the Census. Decennial Census (1980), American Community Survey (2005-2007). 
Table 6

Crime rate (number of crimes per 1000 population)

\begin{tabular}{|c|c|c|c|c|}
\hline & & 1975 & \multicolumn{2}{|c|}{2007} \\
\hline \multirow{12}{*}{ 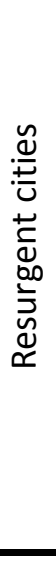 } & & Total & Total & Violent * \\
\hline & Evansville & 63.9 & 50.7 & 4.5 \\
\hline & Fort Wayne & 76.7 & 43.7 & 3.1 \\
\hline & Grand Rapids & 76.1 & 62.5 & 9.7 \\
\hline & Greensboro & 67.4 & 71.8 & 9.7 \\
\hline & Jersey City & 70.0 & 38.3 & 10.1 \\
\hline & New Haven & 128.6 & 42.6 & 10.4 \\
\hline & Peoria & 103.7 & 46.1 & 0.0 \\
\hline & Providence & 83.6 & 53.2 & 5.6 \\
\hline & Winston-Salem & 80.0 & 62.8 & 7.6 \\
\hline & Worcester & 111.5 & 43.0 & 8.7 \\
\hline & Springfield & 83.5 & 66.3 & 13.7 \\
\hline \multirow{3}{*}{ 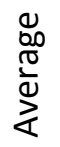 } & All cities & 86.5 & 57.7 & 9.0 \\
\hline & Resurgent cities** & 86.2 & 51.5 & 6.9 \\
\hline & Other cities** & 86.8 & 61.7 & 10.3 \\
\hline
\end{tabular}

*Violent crime includes murder, rape, aggravated assault, and robbery.

**Averages for the resurgent cities are statistically significantly different from the averages for the other cities in 2007 at the $90 \%$ level of confidence.

Source: U.S. Bureau of the Census. County and City Data Book (1975 and 2000); U.S. Department of Justice, Federal Bureau of Investigation. Crime in the United States, 2007. 


\section{Appendix Table 1}

Population and Resident Manufacturing Employment Shares for Springfield and Peer-Group Cities, 1960 to 1980 (in order of manufacturing share in 1960)

\begin{tabular}{|c|c|c|c|c|c|c|c|c|}
\hline \multirow[b]{2}{*}{ City } & \multirow[b]{2}{*}{ State } & \multirow[b]{2}{*}{ Region } & \multicolumn{3}{|c|}{ Population } & \multicolumn{3}{|c|}{ Manufacturing Industry Share } \\
\hline & & & 1960 & 1970 & 1980 & 1960 & 1970 & 1980 \\
\hline Waterbury & $\mathrm{CT}$ & Northeast & 107,130 & 108,033 & 103,266 & 51.7 & 39.9 & 40.5 \\
\hline Gary & IN & Midwest & 178,320 & 175,249 & 151,953 & 50.5 & 46.8 & 42.9 \\
\hline Flint & $\mathrm{Ml}$ & Midwest & 196,940 & 193,380 & 159,611 & 50.5 & 43.8 & 42.2 \\
\hline Bridgeport & $\mathrm{CT}$ & Northeast & 156,748 & 156,546 & 142,546 & 45.0 & 38.0 & 39.9 \\
\hline Paterson & NJ & Northeast & 143,663 & 144,830 & 137,970 & 44.7 & 36.0 & 43.6 \\
\hline Rockford & IL & Midwest & 126,706 & 147,205 & 139,712 & 44.6 & 40.6 & 38.1 \\
\hline Akron & $\mathrm{OH}$ & Midwest & 290,351 & 275,425 & 237,177 & 44.0 & 38.4 & 29.5 \\
\hline Allentown & PA & Northeast & 108,347 & 109,521 & 103,758 & 41.7 & 37.2 & 35.7 \\
\hline Rochester & NY & Northeast & 318,611 & 295,011 & 241,741 & 41.2 & 38.5 & 34.5 \\
\hline Youngstown & $\mathrm{OH}$ & Midwest & 166,689 & 139,702 & 115,436 & 41.0 & 36.4 & 30.6 \\
\hline Erie & PA & Northeast & 138,440 & 129,220 & 119,123 & 40.2 & 38.1 & 34.0 \\
\hline South Bend & IN & Midwest & 132,445 & 125,802 & 109,727 & 39.4 & 30.0 & 26.4 \\
\hline Worcester & MA & Northeast & 186,587 & 176,603 & 161,799 & 37.9 & 28.9 & 27.2 \\
\hline Dayton & $\mathrm{OH}$ & Midwest & 262,332 & 243,459 & 203,371 & 36.4 & 32.7 & 22.6 \\
\hline Winston-Salem & NC & South & 111,135 & 132,901 & 131,885 & 36.2 & 31.5 & 27.2 \\
\hline Grand Rapids & $\mathrm{MI}$ & Midwest & 177,313 & 197,534 & 181,843 & 34.8 & 28.5 & 27.6 \\
\hline Providence & $\mathrm{RI}$ & Northeast & 207,498 & 179,223 & 156,804 & 34.5 & 29.2 & 31.7 \\
\hline Springfield & MA & Northeast & 174,463 & 163,886 & 152,319 & 33.9 & 27.7 & 28.1 \\
\hline Jersey City & NJ & Northeast & 276,101 & 260,350 & 223,532 & 33.2 & 29.4 & 25.4 \\
\hline Fort Wayne & IN & Midwest & 161,776 & 177,738 & 172,196 & 32.2 & 30.2 & 26.0 \\
\hline Peoria & IL & Midwest & 103,162 & 126,964 & 124,160 & 32.0 & 28.2 & 26.3 \\
\hline New Haven & $\mathrm{CT}$ & Northeast & 152,048 & 137,715 & 126,109 & 31.5 & 21.5 & 23.1 \\
\hline Syracuse & NY & Northeast & 216,038 & 197,270 & 170,105 & 31.3 & 22.5 & 20.6 \\
\hline Evansville & IN & Midwest & 141,543 & 138,690 & 130,496 & 30.6 & 30.1 & 26.1 \\
\hline Hartford & $\mathrm{CT}$ & Northeast & 162,178 & 158,017 & 136,392 & 30.1 & 21.1 & 24.1 \\
\hline Greensboro & $\mathrm{NC}$ & South & 119,574 & 144,245 & 155,642 & 29.5 & 26.6 & 25.4 \\
\hline
\end{tabular}

Note: In this table, the shaded rows provide data for resurgent cities, and the unshaded rows provide data for Springfield and the other remaining cities.

Source: U.S. Bureau of the Census. County and City Data Book (1960 and 1970), Decennial Census (1980). 
Appendix Table 2

Population, 1960 to 2005-07

\begin{tabular}{|l|cccc|}
\hline City & $\mathbf{1 9 6 0}$ & $\mathbf{1 9 8 0}$ & $\mathbf{2 0 0 0}$ & $\mathbf{2 0 0 5 - 0 7}$ \\
Akron & $\mathbf{2 9 0 , 3 5 1}$ & 237,177 & 217,074 & 200,172 \\
Allentown & 108,347 & 103,758 & 106,632 & 108,900 \\
Bridgeport & 156,748 & 142,546 & 139,529 & 130,748 \\
Dayton & 262,332 & 203,371 & 166,179 & 146,762 \\
Erie & 138,440 & 119,123 & 103,717 & 100,393 \\
Evansville & 141,543 & 130,496 & 121,582 & 113,627 \\
Flint & 196,940 & 159,611 & 124,943 & 108,304 \\
Fort Wayne & 161,776 & 172,196 & 205,727 & 249,830 \\
Gary & 178,320 & 151,953 & 102,746 & 86,723 \\
Grand Rapids & 177,313 & 181,843 & 197,800 & 193,671 \\
Greensboro & 119,574 & 155,642 & 223,891 & 237,423 \\
Hartford & 162,178 & 136,392 & 121,578 & 118,655 \\
Jersey City & 276,101 & 223,532 & 240,055 & 234,914 \\
New Haven & 152,048 & 126,109 & 123,626 & 123,507 \\
Paterson & 143,663 & 137,970 & 149,222 & 142,443 \\
Peoria & 103,162 & 124,160 & 112,936 & 111,351 \\
Providence & 207,498 & 156,804 & 173,618 & 170,220 \\
Rochester & 318,611 & 241,741 & 219,773 & 199,697 \\
Rockford & 126,706 & 139,712 & 150,115 & 147,794 \\
South Bend & 132,445 & 109,727 & 107,789 & 98,516 \\
Springfield & $\mathbf{1 7 4 , 4 6 3}$ & $\mathbf{1 5 2 , 3 1 9}$ & $\mathbf{1 5 2 , 0 8 2}$ & $\mathbf{1 4 8 , 1 3 6}$ \\
Syracuse & 216,038 & 170,105 & 147,306 & 139,896 \\
Waterbury & 107,130 & 103,266 & 107,271 & 108,554 \\
Winston-Salem & 111,135 & 131,885 & 185,776 & 213,889 \\
Worcester & 186,587 & 161,799 & 172,648 & 165,965 \\
Youngstown & 166,689 & 115,436 & 82,026 & 68,592 \\
\hline Source:U.S. Bureaus
\end{tabular}

Source: U.S. Bureau of the Census. County and City Data Book (1960), Decennial Census (1980 and 2000), American Community Survey (2005-2007). 


\section{Appendix Table 3}

Median family income and population poverty rate*

\begin{tabular}{|c|c|c|c|c|c|c|c|c|}
\hline \multirow[b]{3}{*}{ City } & \multicolumn{5}{|c|}{ Median family income } & \multirow{2}{*}{\multicolumn{3}{|c|}{$\begin{array}{l}\text { Population poverty rate } \\
\text { (percent) }\end{array}$}} \\
\hline & \multicolumn{4}{|c|}{ Percent of U.S. median } & \multirow{2}{*}{$\frac{\text { Level }(\$ 2007)}{2005-07}$} & & & \\
\hline & 1960 & 1980 & 2000 & 2005-07 & & 1980 & 2000 & 2005-07 \\
\hline Akron & 114.2 & 90.5 & 78.7 & 69.0 & 41,649 & 15.0 & 17.5 & 21.4 \\
\hline Allentown & 106.9 & 97.2 & 74.6 & 67.1 & 40,492 & 11.7 & 18.5 & 22.3 \\
\hline Bridgeport & 105.7 & 83.8 & 79.1 & 76.8 & 46,340 & 20.4 & 18.4 & 19.2 \\
\hline Dayton & 110.7 & 76.8 & 69.9 & 58.9 & 35,544 & 20.8 & 23.0 & 29.6 \\
\hline Erie & 101.3 & 91.0 & 72.8 & 69.5 & 41,962 & 13.4 & 18.8 & 24.3 \\
\hline Evansville & 93.6 & 91.4 & 82.1 & 76.9 & 46,422 & 12.2 & 13.7 & 17.8 \\
\hline Flint & 112.0 & 100.8 & 62.8 & 55.5 & 33,528 & 16.9 & 26.4 & 33.2 \\
\hline Fort Wayne & 114.7 & 98.3 & 90.0 & 89.4 & 53,977 & 11.0 & 12.5 & 13.9 \\
\hline Gary & 106.1 & 97.8 & 64.4 & 56.7 & 34,262 & 20.4 & 25.8 & 33.2 \\
\hline Grand Rapids & 107.2 & 94.8 & 88.4 & 75.2 & 45,404 & 13.5 & 15.7 & 21.9 \\
\hline Greensboro & 103.3 & 98.2 & 100.3 & 87.8 & 53,016 & 12.8 & 12.3 & 18.7 \\
\hline Hartford & 105.8 & 70.5 & 54.1 & 51.0 & 30,805 & 25.2 & 30.6 & 31.5 \\
\hline Jersey City & 105.1 & 80.9 & 83.2 & 80.1 & 48,387 & 21.2 & 18.6 & 17.4 \\
\hline New Haven & 103.6 & 75.3 & 71.8 & 71.9 & 43,404 & 23.2 & 24.4 & 24.0 \\
\hline Paterson & 97.9 & 71.9 & 70.8 & 63.3 & 38,225 & 25.2 & 22.2 & 24.5 \\
\hline Peoria & 105.3 & 111.9 & 93.7 & 90.7 & 54,762 & 12.3 & 18.8 & 16.9 \\
\hline Providence & 89.6 & 75.1 & 64.1 & 70.2 & 42,392 & 20.4 & 29.1 & 27.2 \\
\hline Rochester & 112.4 & 86.2 & 62.5 & 54.8 & 33,095 & 17.5 & 25.9 & 30.0 \\
\hline Rockford & 121.3 & 109.6 & 90.8 & 78.7 & 47,491 & 10.3 & 14.0 & 20.2 \\
\hline South Bend & 118.1 & 94.9 & 78.0 & 73.5 & 44,400 & 12.1 & 16.7 & 21.6 \\
\hline Springfield & 105.9 & 83.4 & 72.5 & 65.2 & 39,371 & 17.8 & 23.1 & 27.7 \\
\hline Syracuse & 110.4 & 83.3 & 66.0 & 59.0 & 35,646 & 18.4 & 27.3 & 30.7 \\
\hline Waterbury & 115.5 & 91.7 & 84.5 & 76.0 & 45,898 & 14.1 & 16.0 & 18.8 \\
\hline Winston-Salem & 93.9 & 89.1 & 93.1 & 85.6 & 51,668 & 16.4 & 15.2 & 18.6 \\
\hline Worcester & 102.5 & 91.0 & 85.9 & 92.4 & 55,778 & 14.4 & 17.9 & 18.3 \\
\hline Youngstown & 101.6 & 85.1 & 61.3 & 52.9 & 31,948 & 18.2 & 24.8 & 29.6 \\
\hline
\end{tabular}

* U.S. median family income was $\$ 60,374$ (in 2007 inflation-adjusted dollars), and the U.S. poverty rate was 13.3 percent in 2005-07.

Source: U.S. Bureau of the Census. County and City Data Book (1960), Decennial Census (1980 and 2000), American Community Survey (2005-2007). 


\section{Appendix Table 4}

Educational Attainment *

(percent of population 25 years and older)

\begin{tabular}{|l|cccc|cccc|}
\hline \multirow{2}{*}{ City } & \multicolumn{3}{|c|}{ High school diploma or higher } & \multicolumn{4}{c|}{ Bachelor's degree or higher } \\
& $\mathbf{1 9 6 0}$ & $\mathbf{1 9 8 0}$ & $\mathbf{2 0 0 0}$ & $\mathbf{2 0 0 5}-\mathbf{0 7}$ & $\mathbf{1 9 6 0}$ & $\mathbf{1 9 8 0}$ & $\mathbf{2 0 0 0}$ & $\mathbf{2 0 0 5 - 0 7}$ \\
\hline Akron & 40.9 & 62.4 & 80.0 & 84.6 & 6.9 & 12.5 & 18.0 & 19.3 \\
Allentown & 36.1 & 59.7 & 72.7 & 76.5 & 6.3 & 10.9 & 15.4 & 16.7 \\
Bridgeport & 32.4 & 50.7 & 65.0 & 72.0 & 4.7 & 8.7 & 12.2 & 13.6 \\
Dayton & 38.2 & 59.3 & 75.1 & 78.0 & 5.8 & 10.4 & 14.4 & 14.7 \\
Erie & 41.6 & 64.8 & 79.9 & 84.5 & 6.4 & 11.3 & 17.4 & 18.2 \\
Evansville & 39.1 & 61.1 & 80.7 & 82.3 & 6.0 & 11.2 & 16.7 & 16.7 \\
Flint & 41.0 & 60.5 & 74.5 & 80.0 & 5.9 & 9.2 & 11.3 & 12.0 \\
Fort Wayne & 47.4 & 68.7 & 83.2 & 86.8 & 7.7 & 13.3 & 19.4 & 24.7 \\
Gary & 36.0 & 55.0 & 72.7 & 81.3 & 5.1 & 7.6 & 10.1 & 11.7 \\
Grand Rapids & 40.6 & 67.1 & 78.0 & 80.9 & 7.4 & 16.4 & 23.8 & 26.9 \\
Greensboro & 48.4 & 68.6 & 84.3 & 85.4 & 12.9 & 24.6 & 33.9 & 35.2 \\
Hartford & 34.5 & 50.8 & 60.8 & 66.5 & 6.1 & 11.9 & 12.4 & 12.8 \\
Jersey City & 28.4 & 51.2 & 72.6 & 81.3 & 4.2 & 11.7 & 27.5 & 34.4 \\
New Haven & 38.2 & 60.9 & 73.6 & 80.1 & 9.3 & 19.8 & 27.1 & 30.9 \\
Paterson & 24.0 & 42.4 & 58.5 & 67.6 & 3.8 & 6.2 & 8.2 & 8.5 \\
Peoria & 40.0 & 69.6 & 82.8 & 87.6 & 7.1 & 19.4 & 28.0 & 32.1 \\
Providence & 32.7 & 53.4 & 65.8 & 72.4 & 6.8 & 15.7 & 24.4 & 29.4 \\
Rochester & 34.5 & 58.0 & 73.0 & 77.3 & 6.4 & 13.9 & 20.1 & 21.6 \\
Rockford & 43.1 & 66.8 & 77.8 & 79.5 & 7.7 & 14.9 & 19.8 & 18.8 \\
South Bend & 45.6 & 65.6 & 77.7 & 80.6 & 9.3 & 14.7 & 20.3 & 22.4 \\
Springfield & 41.8 & 63.5 & 73.4 & $\mathbf{7 4 . 4}$ & 6.4 & $\mathbf{1 1 . 8}$ & $\mathbf{1 5 . 4}$ & $\mathbf{1 7 . 5}$ \\
Syracuse & 43.5 & 63.6 & 76.2 & 78.9 & 10.7 & 17.9 & 23.2 & 24.0 \\
Waterbury & 34.7 & 55.4 & 71.7 & 78.8 & 4.5 & 9.4 & 13.9 & 14.5 \\
Winston-Salem & 42.2 & 62.2 & 80.2 & 83.9 & 12.1 & 21.9 & 30.3 & 30.4 \\
Worcester & 39.9 & 62.6 & 76.7 & 83.5 & 7.2 & 14.8 & 23.3 & 28.2 \\
Youngstown & 34.5 & 56.0 & 73.2 & 77.1 & 4.7 & 7.3 & 9.7 & 10.4 \\
\hline
\end{tabular}

* U.S. percent of population 25 years and older with high school diploma or higher was 84 percent and the percent with bachelor's degree or higher was 27 percent in 2005-07.

Source: U.S. Bureau of the Census. County and City Data Book (1960), Decennial Census (1980 and 2000), American Community Survey (2005-2007). 


\section{Appendix Table 5}

\section{A. Race*}

(percent of total population**)

\begin{tabular}{|c|c|c|c|c|c|c|c|c|c|c|c|c|}
\hline \multirow[b]{2}{*}{ City } & \multicolumn{4}{|c|}{ White } & \multicolumn{4}{|c|}{ Black } & \multicolumn{4}{|c|}{ All other } \\
\hline & 1960 & 1980 & 2000 & 2005-07 & 1960 & 1980 & 2000 & 2005-07 & 1960 & 1980 & 2000 & 2005-07 \\
\hline Akron & 86.9 & 76.8 & 68.6 & 65.8 & 13.0 & 22.2 & 29.1 & 31.3 & 0.1 & 1.0 & 2.3 & 2.9 \\
\hline Allentown & 99.2 & 93.5 & 75.2 & 66.7 & 0.7 & 3.1 & 8.1 & 10.5 & 0.1 & 3.4 & 16.6 & 22.8 \\
\hline Bridgeport & 90.1 & 68.9 & 47.7 & 47.2 & 9.8 & 21.0 & 32.6 & 35.3 & 0.1 & 10.1 & 19.7 & 17.5 \\
\hline Dayton & 78.1 & 62.1 & 54.4 & 53.5 & 21.8 & 36.9 & 43.9 & 44.7 & 0.1 & 1.1 & 1.7 & 1.7 \\
\hline Erie & 95.1 & 89.2 & 82.5 & 80.9 & 4.8 & 9.7 & 14.5 & 15.0 & 0.1 & 1.1 & 3.0 & 4.0 \\
\hline Evansville & 93.4 & 90.4 & 87.4 & 86.1 & 6.6 & 8.8 & 11.1 & 11.7 & 0.0 & 0.8 & 1.5 & 2.2 \\
\hline Flint & 82.3 & 56.2 & 42.7 & 41.6 & 17.5 & 41.4 & 55.0 & 55.6 & 0.2 & 2.4 & 2.3 & 2.8 \\
\hline Fort Wayne & 92.6 & 83.2 & 77.2 & 78.4 & 7.2 & 14.6 & 17.8 & 15.5 & 0.2 & 2.2 & 5.0 & 6.1 \\
\hline Gary & 61.1 & 25.2 & 12.1 & 10.8 & 38.8 & 70.8 & 85.5 & 86.4 & 0.1 & 4.0 & 2.4 & 2.7 \\
\hline Grand Rapids & 91.7 & 80.9 & 69.5 & 68.5 & 8.0 & 15.7 & 21.1 & 21.1 & 0.3 & 3.3 & 9.4 & 10.4 \\
\hline Greensboro & 74.0 & 65.7 & 56.5 & 52.6 & 25.8 & 33.0 & 38.0 & 39.7 & 0.2 & 1.3 & 5.5 & 7.6 \\
\hline Hartford & 84.5 & 50.3 & 29.3 & 30.4 & 15.3 & 33.9 & 40.2 & 39.6 & 0.2 & 15.8 & 30.4 & 30.0 \\
\hline Jersey City & 86.5 & 57.1 & 36.1 & 35.5 & 13.3 & 27.7 & 30.1 & 28.7 & 0.2 & 15.2 & 33.8 & 35.9 \\
\hline New Haven & 85.1 & 62.1 & 45.2 & 45.7 & 14.5 & 31.9 & 38.9 & 36.8 & 0.4 & 6.0 & 15.9 & 17.6 \\
\hline Paterson & 85.1 & 50.9 & 32.8 & 25.7 & 14.7 & 34.1 & 35.1 & 31.5 & 0.2 & 15.0 & 32.1 & 42.8 \\
\hline Peoria & 90.5 & 81.5 & 70.8 & 67.8 & 9.3 & 16.7 & 25.3 & 26.7 & 0.2 & 1.8 & 3.9 & 5.4 \\
\hline Providence & 94.2 & 81.2 & 58.1 & 50.3 & 5.4 & 11.8 & 15.5 & 15.6 & 0.4 & 7.0 & 26.5 & 34.1 \\
\hline Rochester & 92.4 & 69.5 & 50.2 & 49.3 & 7.4 & 25.8 & 40.1 & 42.2 & 0.2 & 4.7 & 9.7 & 8.5 \\
\hline Rockford & 95.7 & 84.3 & 74.7 & 72.3 & 4.2 & 13.2 & 17.8 & 20.1 & 0.1 & 2.5 & 7.5 & 7.6 \\
\hline South Bend & 90.1 & 79.5 & 68.0 & 65.2 & 9.8 & 18.3 & 25.3 & 25.6 & 0.1 & 2.2 & 6.7 & 9.2 \\
\hline Springfield & 92.3 & 76.1 & 58.5 & 52.4 & 7.5 & 16.6 & 21.9 & 22.4 & 0.2 & 7.4 & 19.6 & 25.1 \\
\hline Syracuse & 94.3 & 81.3 & 66.7 & 63.9 & 5.2 & 15.7 & 26.3 & 28.9 & 0.5 & 3.0 & 7.0 & 7.3 \\
\hline Waterbury & 93.3 & 83.5 & 69.7 & 70.1 & 6.6 & 11.6 & 16.9 & 19.0 & 0.1 & 4.8 & 13.4 & 10.9 \\
\hline Winston-Salem & 62.9 & 59.0 & 56.5 & 55.0 & 37.1 & 40.2 & 37.7 & 34.7 & 0.0 & 0.8 & 5.9 & 10.3 \\
\hline Worcester & 98.8 & 93.9 & 79.8 & 79.7 & 1.1 & 2.9 & 7.1 & 9.0 & 0.1 & 3.2 & 13.1 & 11.3 \\
\hline Youngstown & 80.9 & 64.4 & 52.2 & 50.1 & 19.0 & 33.3 & 44.9 & 47.5 & 0.1 & 2.2 & 2.9 & 2.4 \\
\hline
\end{tabular}

* U.S. population was 76 percent white, 13 percent black and 11 percent of all other races in 2005-07.

**In 1960 and 1980, table entries show the numbers of whites, blacks, and all other races as a percent of the population. "All other" refers to Asian, American Indian and Alaska Native, Native Hawaiian and other Pacific Islander, or some other race. Starting in 2000 respondents could report more than one race. In 2000 and 2005-07, table entries show the numbers of white- alone and black-alone populations as a percent of total single-race population, with all other and mixed races as the residual. There was a sharp increase in the "other race" population in the 1980 Census, reflecting the addition of a question on Hispanic origin, an increased propensity for Hispanics not to identify themselves as white, and a change in editing procedures to accept reports of "other race" for respondents who wrote in Hispanic entries such as Mexican, Cuban, or Puerto Rican. In 1970, such responses in the other race category were reclassified and tabulated as white.

Source: U.S. Bureau of the Census. County and City Data Book (1960); Decennial Census (1980 and 2000); American Community Survey (2005-07). 


\section{B. Race of Non-Hispanic Population*}

(percent of total population**)

\begin{tabular}{|l|cc|cc|cc|}
\hline \multirow{2}{*}{ City } & \multicolumn{2}{|c|}{ White } & \multicolumn{2}{c|}{ Black } & \multicolumn{2}{c|}{ All other } \\
& $\mathbf{2 0 0 0}$ & $\mathbf{2 0 0 5 - 0 7}$ & $\mathbf{2 0 0 0}$ & $\mathbf{2 0 0 5 - 0 7}$ & $\mathbf{2 0 0 0}$ & $\mathbf{2 0 0 5 - 0 7}$ \\
\hline Akron & 68.3 & 64.6 & 28.8 & 31.1 & 2.9 & 4.3 \\
Allentown & 66.9 & 54.6 & 6.6 & 9.2 & 26.5 & 36.2 \\
Bridgeport & 32.9 & 26.2 & 31.0 & 34.5 & 36.0 & 39.2 \\
Dayton & 53.7 & 52.7 & 44.0 & 44.6 & 2.3 & 2.7 \\
Erie & 80.9 & 78.5 & 14.2 & 14.7 & 4.9 & 6.8 \\
Evansville & 86.9 & 85.4 & 10.6 & 11.6 & 2.5 & 3.0 \\
Flint & 41.8 & 40.5 & 54.1 & 55.4 & 4.0 & 4.1 \\
Fort Wayne & 75.0 & 75.5 & 17.5 & 15.3 & 7.5 & 9.1 \\
Gary & 10.1 & 9.1 & 84.9 & 86.0 & 5.0 & 4.9 \\
Grand Rapids & 64.6 & 61.2 & 20.6 & 20.8 & 14.7 & 18.0 \\
Greensboro & 54.7 & 49.7 & 37.8 & 39.6 & 7.6 & 10.7 \\
Hartford & 18.8 & 17.2 & 38.3 & 38.2 & 42.9 & 44.5 \\
Jersey City & 25.1 & 24.8 & 28.3 & 27.0 & 46.6 & 48.2 \\
New Haven & 37.2 & 34.6 & 37.2 & 35.9 & 25.6 & 29.5 \\
Paterson & 14.0 & 11.4 & 33.5 & 30.5 & 52.5 & 58.1 \\
Peoria & 69.9 & 66.8 & 24.9 & 26.6 & 5.1 & 6.7 \\
Providence & 49.0 & 42.5 & 13.1 & 13.7 & 38.0 & 43.8 \\
Rochester & 46.4 & 42.2 & 38.7 & 41.2 & 15.0 & 16.6 \\
Rockford & 70.5 & 64.0 & 17.5 & 20.0 & 12.0 & 16.0 \\
South Bend & 65.3 & 61.7 & 24.8 & 25.2 & 9.8 & 13.1 \\
Springfield & $\mathbf{5 0 . 9}$ & $\mathbf{4 2 . 5}$ & $\mathbf{2 0 . 4}$ & $\mathbf{2 1 . 8}$ & $\mathbf{2 8 . 7}$ & $\mathbf{3 5 . 7}$ \\
Syracuse & 64.9 & 60.5 & 25.4 & 27.9 & 9.7 & 11.7 \\
Waterbury & 60.4 & 53.4 & 15.7 & 17.8 & 23.9 & 28.9 \\
Winston-Salem & 53.4 & 51.2 & 37.1 & 34.6 & 9.5 & 14.2 \\
Worcester & 73.4 & 67.9 & 6.7 & 8.4 & 20.0 & 23.7 \\
Youngstown & 50.7 & 45.9 & 43.9 & 46.9 & 5.4 & 7.2 \\
\hline
\end{tabular}

*U.S. non-Hispanic white-alone population accounted for 68 percent of the total single-race population and non-Hispanic black-alone for 12 percent of the total single-race population in 2005-07.

** Table entries show the number of non-Hispanic white-alone and non-Hispanic black-alone populations as a percent of the total single-race population, with all other and mixed races as the residual.

Source: U.S. Bureau of the Census. Decennial Census (2000); American Community Survey (2005-07). 
C. Hispanic population* (percent of total population)

\begin{tabular}{|l|ccc|}
\hline & & & \\
& $\mathbf{1 9 8 0}$ & $\mathbf{2 0 0 0}$ & $\mathbf{2 0 0 5}-\mathbf{0 7}$ \\
\hline Akron & 0.6 & 1.2 & 1.7 \\
Allentown & 5.1 & 24.4 & 34.6 \\
Bridgeport & 18.7 & 31.9 & 33.3 \\
Dayton & 0.9 & 1.6 & 1.8 \\
Erie & 1.1 & 4.4 & 5.4 \\
Evansville & 0.5 & 1.1 & 1.5 \\
Flint & 2.5 & 3.0 & 3.5 \\
Fort Wayne & 2.2 & 5.8 & 6.8 \\
Gary & 7.1 & 4.9 & 4.8 \\
Grand Rapids & 3.2 & 13.1 & 16.4 \\
Greensboro & 0.8 & 4.4 & 6.5 \\
Hartford & 20.5 & 40.5 & 41.1 \\
Jersey City & 18.6 & 28.3 & 27.7 \\
New Haven & 8.0 & 21.4 & 24.0 \\
Paterson & 28.7 & 50.1 & 55.3 \\
Peoria & 1.4 & 2.5 & 2.9 \\
Providence & 5.8 & 30.0 & 36.0 \\
Rochester & 5.4 & 12.8 & 13.6 \\
Rockford & 2.9 & 10.2 & 13.9 \\
South Bend & 2.4 & 8.5 & 10.8 \\
Springfield & $\mathbf{9 . 1}$ & $\mathbf{2 7 . 2}$ & $\mathbf{3 3 . 6}$ \\
Syracuse & 1.7 & 5.3 & 6.0 \\
Waterbury & 6.7 & 21.8 & 27.1 \\
Winston-Salem & 0.8 & 8.6 & 12.2 \\
Worcester & 4.3 & 15.1 & 17.7 \\
Youngstown & 3.3 & 5.2 & 6.8 \\
\hline
\end{tabular}

*The share of Hispanic population in the U.S. was 15 percent in 2005-07.

Source: U.S. Bureau of the Census. Decennial Census (1980 and 2000), American Community Survey (2005-2007). 


\section{Appendix Table 6}

Crime Rate*

(number of crimes per 1,000 population)

\begin{tabular}{|l|c|c|c|c|}
\hline & & & \multicolumn{2}{|c|}{2007} \\
\cline { 4 - 5 } City & 1975 & $\mathbf{2 0 0 0}$ & Total & Violent** \\
\hline Akron & 87.4 & NA & 57.8 & 7.5 \\
Allentown & 58.2 & 53.8 & 57.7 & 8.1 \\
Bridgeport & 96.7 & 62.6 & 59.4 & 11.6 \\
Dayton & 133.5 & 95.9 & 77.6 & 10.3 \\
Erie & 46.7 & 36.9 & 35.5 & 5.3 \\
Evansville & 63.9 & 49.8 & 50.7 & 4.5 \\
Flint & 125.9 & 83.5 & 86.1 & 23.6 \\
Fort Wayne & 76.7 & 60.2 & 43.7 & 3.1 \\
Gary & 77.2 & 55.8 & 55.0 & 6.9 \\
Grand Rapids & 76.1 & 69.4 & 62.5 & 9.7 \\
Greensboro & 67.4 & 71.3 & 71.8 & 9.7 \\
Hartford & 136.4 & 84.2 & 69.2 & 11.3 \\
Jersey City & 70.0 & 52.2 & 38.3 & 10.1 \\
New Haven & 128.6 & 76.7 & 42.6 & 10.4 \\
Paterson & 89.1 & 41.9 & 39.5 & 10.0 \\
Peoria & 103.7 & NA & 46.1 & 0.0 \\
Providence & 83.6 & 81.0 & 53.2 & 5.6 \\
Rochester & 88.3 & 77.1 & 65.9 & 11.4 \\
Rockford & 76.2 & NA & 73.4 & 13.5 \\
South Bend & 88.7 & 83.9 & 73.5 & 7.7 \\
Springfield & 83.5 & 81.8 & 66.3 & 13.7 \\
Syracuse & 69.5 & 58.1 & 52.9 & 10.3 \\
Waterbury & 70.6 & NA & 56.8 & 3.6 \\
Winston-Salem & 80.0 & 94.7 & 62.8 & 7.6 \\
Worcester & 111.5 & 51.4 & 43.0 & 8.7 \\
Youngstown & 60.5 & 75.4 & 60.3 & 10.0 \\
\hline
\end{tabular}

Source: U.S. Bureau of the Census. County cand City Data Book (1975 and 2000); U.S.

Department of Justice, Federal Bureau of Investigation. Crime in the United States, 2007.

* U.S. total crime and violent crime rates were 37.3 and 4.7, respectively, in 2007.

**Violent crime includes murder, rape, aggravated assault and robbery. 